\author{
UNIVERSIDADE DE SÃO PAULO \\ FACULDADE DE ODONTOLOGIA DE BAURU
}

\begin{abstract}
“ESTABILIDADE DA CORREÇÃO DA CLASSE II,
1․ DIVISÃO COM O APARELHO BIONATOR DE BALTERS ASSOCIADO AO APARELHO FIXO "
\end{abstract}

MANOELA FÁVARO FRANCISCONI 



\section{“ESTABILIDADE DA CORREÇÃO DA CLASSE II, 1ㅁ DIVISÃO COM O APARELHO BIONATOR DE BALTERS ASSOCIADO AO APARELHO FIXO "}

Dissertação apresentada à Faculdade de Odontologia de Bauru, da Universidade de São Paulo, como parte dos requisitos para obtenção do título de Mestre em Odontologia.

Área de Concentração: Ortodontia

Orientador:

Prof. Dr. José Fernando Castanha Henriques 


\section{Francisconi, Manoela Fávaro}

F847e Estabilidade da correção da Classe II, $1^{\text {a }}$ divisão com o aparelho Bionator de Balters associado ao aparelho fixo/ Manoela Fávaro Francisconi. -- Bauru, 2010.

185p. : il. ; $30 \mathrm{~cm}$

Dissertação (Mestrado) -- Faculdade de Odontologia de Bauru. Universidade de São Paulo.

Orientador: Prof. Dr. José Fernando Castanha Henriques

Autorizo, exclusivamente para fins acadêmicos e científicos, a reprodução total ou parcial desta dissertação, por processos fotocopiadores e outros meios eletrônicos.

Assinatura:

Data:

Projeto de pesquisa aprovado pelo Comitê de Ética em Pesquisa da Faculdade de Odontologia de Bauru, Universidade de São Paulo, (Processo $n^{\circ}$ 062/2009) em 27 de maio de 2009. 




\section{MANOELA FÁVARO FRANCISCONI}

22 DE JUNHO DE 1986

FILIAÇÃO

$2004-2007$

$2005-2007$

$2008-2010$

$2009-2011$

ASSOCIAÇÕES
Nascimento

Dois Córregos - SP

Paulo Afonso Silveira Francisconi Marinelci Fávaro Francisconi

Curso de Graduação em Odontologia pela Faculdade de Odontologia de Bauru da Universidade de São Paulo (FOB-USP)

Bolsista do Programa de Educação Tutorial pertencente à Secretaria de Ensino Superior (PET- SESu)

Especialização em Ortodontia pela Uningá - Bauru - SP

Curso de Pós-Graduação em Ortodontia, ao nível de Mestrado, pela Faculdade de Odontologia de Bauru Universidade de São Paulo

SBPqO - Sociedade Brasileira de Pesquisas Odontológicas.

APCD - Associação Paulista de Cirurgiões-Dentistas 

"A ciência é o nutriente da inteligência, enquanto a fé é o alimento da alma. A ciência exige pesquisa, a fé exige contemplação e estudo. Onde termina o limite estreito de alcance da ciência, começa o horizonte infinito da fé. Ambas se completam. (Prof. Felipe Aquino)" 



\section{Dedicatóría}

Dedico este trabalho especialmente à minha familia, meu maior exemplo, rocha sobre a qual edifico os principios que me motivam a lutar em busca dos meus ideaís e da realização de todos os meus sonhos...

$\mathcal{A}$ Deus,

por me fazer acreditar que tudo é possivel quando se tem fé e por estar ao meu lado, incondicionalmente, amparando-me em seus braços confortantes.

Aos meus pais, Paulo e Marinelci,

por serem exemplo de vida a ser seguido e por nos darem um amor tão intenso e insubstituível, que fícaría impossível pensar em víver um só instante longe de vocês... Obrigada pelo carinho, por cada conselho, cada oração, cada palavra de apoío, enfím, por cada esforço para poder ver suas fíthas felizes. Agradeço ao meu pai pelo exemplo de professor que é, dentro desta faculdade, e por assim me incentivar a conquistar meus objetivos profíssionais, estando sempre ao meu lado; à minha mãe por demonstrar sua grande determinação diante da vida e dos sonhos, ensinando-nos a lutar pelos nossos ideais, sem nunca desistir. Procuro me espelhar no exemplo de vocês para que um día eu possa ser, ao menos, um pouquínho daquilo que vocês são. Paí e Mãe, amo vocês maís que tudo! Muito obrigada por fazerem de nós as filhas mais felizes deste mundo! 



\section{Às minhas irmãs, Carolina e Luciana,}

por estarem ao meu lado incondicionalmente e me ajudarem a ser o que sou. Por cada minuto de nossas conversas e trocas de experiências. $\mathcal{A}$ Carol, minha irmãzinha inseparável, por estar sempre ao meu lado dando os melhores conselhos e liçôes de vída. $\mathcal{A} \mathfrak{L} u$, por ser minha prima, irmã, madrinha, amiga, colega de faculdade e do $\mathcal{P} \mathcal{E}$; por estar ao meu lado sempre e me ajudar em simplesmente, tudo que eu preciso... Sinceramente, não sei o que sería da minha vida sem vocês... Agradeço também pela preocupação, paciência e compreensão que sempre tiveram comigo. Obrigada pela força. Saibam que eu nunca podería viver sem vocês. Espero que eu possa retribuir todo o amor, carinho e atenção que vocês me dão.

\section{Ao meu amado noivo Pedro,}

por ter me ensinado o real significado da palavra amar. Por sempre me apoiar, incentivar e mostrar que não devemos medir o tamanho de nossos sonhos. Por sempre estar ao meu lado, por me fazer sentir a pessoa mais feliz desse mundo, por me dar todo o carinho, a atenção e o amor que possa existir dentro dele e por ser a pessoa que eu escolhi para viver ao meu lado por toda a vida. Te amo pra sempre Pê, você é tudo pra mim!

\section{À minha irmã do coração, Grazi,}

Talvez a vida tenha sido um tanto quanto paradoxal conosco. Ao mesmo tempo que causou perdas irreparáveis, também nos deu uma irmã maravilhosa... Ter você, sempre ao nosso lado, é o melhor presente que Deus poderia nos fornecer... Muito obrigada pelo carinho, atenção $e$ companheirismo que tem com toda a nossa família! Ter uma irmã, um pouquinho mais vetha e especial como você, faz das nossas vidas muito mais felizes! 



\section{Agradecimento especial}

Ao meu orientador Prof. Dr. José Fernando Castanha

Henriques, pela disponibilidade em me orientar neste trabalho. Agradeço pelo estímulo ao meu crescímento na vída acadêmíca e por ter-me orientado de forma sábía, respeitando minhas opinióes e, ao mesmo tempo, guiando-me pelo melhor caminho. Agradeço também pela amizade e carínho dispensados a mím e a toda a minha famílía. Além da orientação, também se tornou um grande amigo, pelo qual tenho grande admiração e carinho. Acima de tudo, obrigada pelo exemplo de humildade e força de vontade que transmite a todos ao seu redor. Serei sempre grata ao senhor. 



\section{Agradecimentos}

Ao Prof. Dr. Guitherme Janson, coordenador do curso de Mestrado em Ortodontía da FOB-USP, pela oportunidade que me deu de ampliar meus horizontes acadêmicos e profissionais. Com seu espirito determinado, estimula-me a buscar o conhecimento e a expressar o que há de methor dentro de mim. Muito obrigada pelas preciosas considerações e ensinamentos.

À Prof. ${ }^{\text {D }}$ ra. Daniela Garíb, que com seu jeito calmo e amável de ser, transmite uma infinidade de conhecimentos que tem sobre a Ortodontía, não poupando esforços para nos ajudar. Muito obrigada pelos ensinamentos, pela sua dedicação e pela nossa amizade.

Ao Prof. Dr. Marcos Roberto de Freitas, que com seu jeito amável e irreverente nos ensina a enfrentar as dificuldades do aprendizado com tranqüilidade $e$ perseverança. Serei sempre grata por sua gentileza, respeito e atenção.

Ao Prof. Dr. Arnaldo Pinzan, que sempre se preocupou com nosso aprendizado, enriquecendo nossos seminários. Obrigada pelos ensinamentos que contribuiram para a minha formação profissional e pela amizade.

$\mathcal{A}$ o Prof. Dr. Renato Rodrígues de $\mathcal{A}$ lmeida, o primeiro contato que tive com a Ortodontia, ainda nas aulas de graduação, mostrou com entusiasmo as maravithas da especialidade. Com seu rigor didático, contribuiu demasiado para minha formação profissional. 

Aos meus tíos e primos, tío Já, tía Cena, tío Pedro, Renato, Fernando, Nathália, Rafinha e Gabi

por serem muito mais que simples familiares, e por ocuparem lugar mais do que especial em meu coração. Agradeço ao tío Já pelo exemplo de profíssional que é, e por me incentivir a conquistar todos os meus objetivos; $a ̀$ tía Cena por toda a sua dedicação com aqueles que mais precisam e por sempre me entender nas horas difíceis; ao Rê, ao Fer, à $\mathcal{N a t i , ~ a o ~ R a f a ~ e ~ a ̀ ~}$ Gabi por estarem ao meu lado sempre e fazerem parte da minha vida. Admiro vocês e torço para que tenham um futuro tão brîthante quanto merecem. Amo muito vocês.

Aos meus avós, Pedro e Eunísia; Helena e Eugênio,

por serem vozes da experiência que me inspiram na luta pelos meus ideaís. Vô Pedro e Vó Jísía, obrigada pelo exemplo de vida e por me fazerem acreditar que nenhum obstáculo pode ser maior que a vontade de vencer. Vó Helena, obrigada pelas orações e pela preocupação, e também por estar ao meu lado sempre. Vô Geninho, obrigada por guiar meus passos e me proteger aí do céu. Agradeço vocês por me acompanharem desde quando sonhavam em ter mais uma netinha.

Aos meus sogros Paulo e Elliane,

exemplos de dedicação ao trabalho e à famílía. Tío Paulo, obrígada por seu exemplo de determinação e por acolher-me como uma fílha. Tía Lillí, obrigada pelo carínho, apreço e doação. Você nos inspira com sua incontestável alegria de viver e por enxergar, nas coisas simples, a verdadeira felicidade. Obrigada pelo incentivo, compreensão e por estarem sempre ao meu lado. Ser parte da familia de vocês é motivo de orgulho para mim. 

Aos meus cunhados e às minhas cunhadas queridas, Pri e Ger, Paulo e Thalita, Ni e Gu,

sempre alegres e dispostos a ajudar. Noão sería nada sem vocês no meu dia-a-dia. Muito obrigada pelo apoio, pela amizade, pela consideração. Tenho certeza de que vocês são os responsáveis por dar britho à minha vida. Vocês são maís do que especiaís para mim. Muito obrigada!

Às minhas amigas, Tai, Paulinha, Rê e Ju,

verdadeiros presentes que a vida me deu ao longo dos anos. Ter amigas como vocês me faz ver o quanto é bom compartithar os sonhos e dividir as alegrias. Agradeço pelo apoío incondicional e por nunca me deixarem desistir.

Aos colegas do curso de Mestrado: Beto, Tai, Caroline, Amanda, Renata, Juliana, Carolina, Patrícía, Suelen, Laura e Daniel

Agradeço pelos ótimos momentos que passamos juntos. Obrigada pela paciência, amizade e troca de experiência. Vocês fizeram minha caminhada mais leve e alegre e me ajudaram a superar as dificuldades cotidianas. Tenho excelentes recordações de cada um de vocês. Vocês serão profissionais inigualáveís, tenho certeza disso.

Aos colegas da turma do Doutorado novo: Eduardo Lenza, Michele, Marinês, Eliziane, Luís Eduardo, Juliana, Nuria, Renata, Thaís,

pelo apoío dado durante esta jornada. Em especial à Thaís, que é um exemplo de vida e amor à família. Muito obrigada pela amizade! 



\section{À Karina María Salvatore de Freitas,}

por toda ajuda concedida, por todas as palavras de conforto, por todas as vezes que me livrou dos sufocos, por estar sempre disposta a me ajudar, por ter o coração maior que o mundo, por não poupar esforços, por estar sempre pronta à todos que precisam dela, por ser um exemplo de determinação e por ser muito maís do que uma amiga para mím. Ká, te adoro, você é mais do que especial.

Aos meus professores da Graduação da FOB,

os quais participaram de uma etapa tão importante de minha vida.

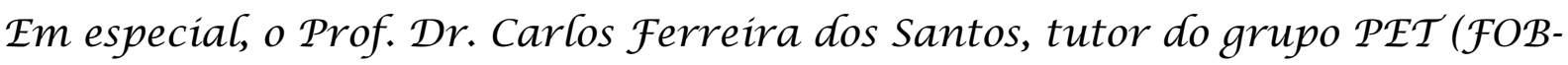
USP), pela oportunidade que me deu de participar deste programa, ampliando meus horizontes profissionais e acadêmicos, e quem muito me apoiou para ingressar no Mestrado.

Aos funcionários da disciplina de Ortodontia, Cris, Sérgio, Vagner, Verinha, Neide e Bonné,

pela dedicação, pelo incentivo, colaboração e ajuda e por serem amigos de todas as horas.

Aos funcionários e amigos de longa data do Departamento de Materiais Dentários, Sandrinha, Lô e Alcides,

por serem, na realidade, uma extensão da família Francisconí. Obrigada pela companhía diáría e por não pouparem esforços para que tudo desse certo. 

Ao Prof. Dr. Roberto Laurís e à sua esposa Dr. ${ }^{\text {a }}$ Rita de Cássía Laurís,

por me ajudarem a compreender e a aprender um pouco mais sobre a estatística e a ortodontía, respectivamente. Ter convivido com vocês esse ano foi, simplesmente, maravilhoso. Obrigada pela carinho, atenção e pela amizade com a minha familia.

Aos funcionários da Bíblioteca e todos os demaís funcionários desta instituição,

sempre solicitos e prontos para esclarecer nossas dúvidas. Obrigada pela atenção e dedicação.

Ao Prof. Dr. José Carlos Pereira,

Diretor da Faculdade de Odontologia de Bauru - USP. Obrigada pela atenção e carinho dispensados à mim e à toda minha famílía!

\section{À Prof. Dra. Maria Aparecida de Andrade Moreira Machado,}

presidente da Comissão de Pós-Graduação da Faculdade de Odontología de Bauru - USP.

\section{À $C \mathcal{A P E S}$}

pela concessão de bolsa de estudo durante o período de Mestrado e à $\mathcal{P R O A P}$ pelo auxílio concedido nas participações de eventos científicos.

Por fim, a DEUS, por iluminar o meu caminho e fazer com que eu encontre equilíbrio e felicidade em tudo o que realizo. 

Resumo 



\section{RESUMO}

Recursos ortopédicos e ortodônticos, utilizados de forma associada, têm se mostrado uma opção terapêutica eficiente no tratamento da má oclusão de Classe II, $1^{\text {a }}$ divisão desde que o paciente ainda apresente um potencial de crescimento favorável. Entretanto, as alterações nas relações esqueléticas, dentárias e tegumentares só podem ser consideradas satisfatórias caso permaneçam estáveis. Assim, este trabalho teve o propósito de avaliar cefalometricamente e por meio de modelos de estudo, a estabilidade das alterações decorrentes do tratamento com o aparelho Bionator de Balters, seguido do aparelho fixo, após um período médio de 10 anos. $O$ grupo experimental compreendeu 23 pacientes que foram avaliados em três fases: inicial (T1), final (T2) e longo tempo pós-tratamento (T3). Foram avaliadas as telerradiografias em norma lateral (inicial, final e longo tempo pós-tratamento), totalizando 69 telerradiografias, e foram mensurados 69 modelos de estudo, avaliados nas fases previamente descritas, através do índice PAR. Também calculou-se a diferença entre o PAR inicial e o PAR final, a \% de melhora obtida com esta terapia e a \% de recidiva, ambas através do índice PAR. As variáveis analisadas foram comparadas por meio da análise de variância (ANOVA) para medidas repetidas e o teste de comparações múltiplas de Tukey. A terapia estudada não propiciou alterações no desenvolvimento maxilar. Observou-se um aumento na protrusão mandibular, bem como um maior incremento no comprimento efetivo da mandíbula. A relação maxilomandibular foi corrigida, notou-se uma melhora na convexidade facial, com a diminuição do ângulo ANB. Alterações significantes no padrão de crescimento craniofacial não foram observadas. Verificou-se, através da variável FMA e no período de longo tempo pós-tratamento, uma rotação do plano mandibular no sentido anti-horário. O posicionamento vertical da maxila (SN.PP) também não se alterou. Os incisivos superiores sofreram lingualização e retrusão. Os primeiros molares superiores mostraram um pequeno aumento no sentido vertical semelhante ao fisiológico, que ocorre pelo processo de flutuação normal. Em contrapartida, os incisivos inferiores sofreram vestibularização e protrusão. Os primeiros molares inferiores, por sua vez, apresentaram um deslocamento no 

sentido vertical (extrusão) e horizontal (mesialização), contribuindo, assim, para a correção da má-oclusão de $\mathrm{Cl}$ II. O tratamento também foi efetivo em corrigir os respasses, horizontal e vertical, bem como a relação molar. O ângulo nasolabial não foi afetado pelo tratamento, mostrando que os aparelhos ortopédicos não afetam substancialmente esta variável. Além disso, é de suma importância, ressaltarmos que, as alterações obtidas, com o tratamento realizado, permaneceram estáveis no período de longo tempo pós-tratamento; demostrando, dessa maneira, a efetividade da terapia selecionada. Finalmente, na análise dos modelos de estudo, os valores do índice PAR sofreram uma redução estatisticamente significante e permaneceram estáveis no período de longo tempo pós-tratamento. A porcentagem de melhora obtida com esta terapia foi de $81,78 \%$ e a de recidiva foi de 4,90\%. Esses dados refletem que o Bionator de Balters, associado ao aparelho fixo, é uma efetiva alternativa para o tratamento da má-oclusão de $\mathrm{Cl}$ II, 1a divisão.

Palavras-chave: Má Oclusão de Angle Classe II. Aparelhos Ortodônticos Funcionais. Ortodontia Corretiva. Recidiva. 

Abstract 



\section{ABSTRACT \\ Stability of the correction of the Class II, division 1 malocclusion with the Balters' Bionator associated to fixed appliances}

Orthopedic and orthodontic approaches, used in an associated way, are being considered an efficient therapeutic option for the treatment of the Class II, division 1 malocclusion when the patient still presents a favorable growth potential. However, changes in skeletal, dental and soft tissue relationships only can be considered satisfactory if they remain stable. This study aimed to evaluate, cephalometrically and in dental casts, the stability of the changes resulting from the treatment with the Balters' Bionator followed by the fixed appliances, after a mean period of 10 years. The experimental group comprised 23 patients who were evaluated in three stages: initial (T1), final (T2) and long-term posttreatment (T3). A total of 69 lateral cephalograms (initial, final and long-term posttreatment) were evaluated and also 69 dental casts were measured, in the stages previously described, using the PAR index. Furthermore, the difference between initial PAR and final PAR, the percentage of obtained improvement with the therapy and the percentage of relapse were calculated, using the PAR index. Evaluated variables were compared by the analysis of variance (ANOVA) for repeated measures and Tukey test. The studied therapy did not provide changes in maxillary development. An increase in mandibular protrusion, as well as a greater increase in effective length of the mandible, was observed. The maxillomandibular relationship was corrected, and an improvement in the facial convexity was observed, with a decrease of the ANB angle. Significant changes in craniofacial growth were not observed. The analysis of the FMA variable and of the long-term posttreatment revealed a rotation of the mandibular plane in a counterclockwise direction. The vertical positioning of the maxilla (SN.PP) also did not change. The maxillary incisors presented a palatal inclination and retrusion. The maxillary first molars showed a small increase in the vertical direction, similar to the physiological one, which occurred by the normal fluctuation process. In contrast, the mandibular incisors presented a buccal inclination and protrusion. The mandibular 

first molars showed a displacement in the vertical (extrusion) and horizontal (mesial) direction, which contributed to the correction of the Class II malocclusion. The treatment was also effective in correcting the overbite and overjet, and the molar relationship. The nasolabial angle was not affected by treatment, showing that orthopedic appliances did not significantly affect this variable. Finally, the analysis of the dental casts showed that the values of the PAR index presented a statistically significant reduction and remained stable at the long-term posttreatment. The percentage of improvement obtained with this therapy was of $81.78 \%$ and the percentage of relapse was of $4.90 \%$. These data denote that Balters' Bionator associated to the fixed appliances is an effective alternative for the treatment of the Class II, division 1 malocclusion.

Keywords: Malocclusion, Angle Class II. Orthodontic Appliances, Functional. Orthodontics, Corrective. Recurrence. 



\section{LISTA DE FIGURAS}

FIGURA 1 - Aparelho Bionator modificado por Ascher (1977).

FIGURA 2 - Aparelho Bionator - componentes

FIGURA 3 - Aparelho ortodôntico fixo.

FIGURA 4 - Pontos de referência, linhas e planos utilizados 94

FIGURA 5 - Grandezas cefalométricas esqueléticas 97

FIGURA 6 - Grandezas cefalométricas dentárias superiores e inferiores.

FIGURA 7 - Grandezas cefalométricas referentes às relações dentárias. 101

FIGURA 8 - Grandezas cefalométricas referentes ao perfil tegumentar 102

FIGURA 9 - Divisão dos segmentos posteriores e anterior 104

FIGURAS 10 - Variáveis do componente maxilar nas fases inicial (T1), final (T2) e longo tempo pós-tratamento (T3) 127

FIGURAS 11 - Variáveis do componente mandibular nas fases inicial (T1), final (T2) e longo tempo pós-tratamento (T3) 129

FIGURAS 12 - Variáveis da relação maxilomandibular nas fases inicial (T1), final (T2) e longo tempo pós-tratamento (T3) 

FIGURAS 13 - Variáveis do padrão facial nas fases inicial (T1), final (T2) e longo tempo pós-tratamento (T3) 134

FIGURAS 14 - Variáveis do componente vertical nas fases inicial (T1), final (T2) e longo tempo pós-tratamento (T3) 136

FIGURAS 15 - Variáveis do componente dentoalveolar superior nas fases inicial (T1), final (T2) e longo tempo póstratamento (T3) 137

FIGURAS 16 - Variáveis verticais do componente dentoalveolar superior nas fases inicial (T1), final (T2) e longo tempo pós-tratamento (T3) 139

FIGURAS 17 - Variáveis do componente dentoalveolar inferior nas fases inicial (T1), final (T2) e longo tempo póstratamento (T3) 140

FIGURAS 18 - Variáveis verticais do componente dentoalveolar inferior nas fases inicial (T1), final (T2) e longo tempo pós-tratamento (T3) 141

FIGURAS 19 - Variáveis das relações dentárias nas fases inicial (T1), final (T2) e longo tempo pós-tratamento (T3) 142

FIGURA 20 - Variável dos tecidos moles nas fases inicial (T1), final (T2) e longo tempo pós-tratamento (T3) 144

FIGURAS 21 - Valores do índice PAR nas fases inicial (T1), final (T2) e longo tempo pós-tratamento (T3) 145 



\section{LISTA DE TABELAS}

TABELA 1 - Médias, desvios-padrão, valor mínimo e máximo das idades inicial (T1), final (T2), longo tempo póstratamento (T3), período de tratamento (T1-T2) e período de longo tempo pós-tratamento (T2-T3) 85

TABELA 2 - Critérios de aplicação dos escores para os componentes do índice PAR (RICHMOND et al., 1992a)

TABELA 3 - Pesos atribuídos aos diversos componentes do índice PAR segundo o sistema norte-americano (DEGUZMAN et al., 1995) 107

TABELA 4 - Médias, desvios-padrão e resultados do teste $t$ pareado (erro sistemático) e do erro casual (Dahlberg) para a avaliação do erro intra-examinador nas variáveis iniciais, finais e longo tempo pós-tratamento. 114

TABELA 5 - Avaliação das alterações promovidas pelo tratamento e sua estabilidade - Análise de Variância e teste de Tukey, considerando as variáveis cefalométricas.

TABELA 6 - Avaliação das alterações promovidas pelo tratamento e sua estabilidade - Análise de Variância e teste de Tukey, considerando as variáveis de modelos. 116

TABELA 7 - Resultado das alterações do índice PAR durante o período de tratamento e durante o período de longo tempo pós-tratamento. 



\section{SUMÁRIO}

1 INTRODUÇÃO

2.1 A má oclusão de Classe II, $1^{\underline{a}}$ divisão

2.1.1 Tratamento da má oclusão de Classe II, $1^{\text {a }}$ divisão

com ortopedia funcional

2.1.2 Estabilidade do tratamento da má oclusão de Classe

II, $1^{\text {a }}$ divisão com ortopedia funcional.

2.2 Tratamento da má oclusão de Classe II, $1^{\text {a }}$ divisão com o

Bionator de Balters 58

2.2.1 O desenvolvimento do aparelho Bionator e a filosofia de Balters 58

2.2.2 Tipos de aparelho 59

2.2.3 Indicações e contraindicações do Bionator padrão 60

2.2.4 Época de tratamento com o Bionator 61

2.2.5 Efeitos do tratamento com o Bionator 63

2.2.6 Tempo de tratamento com o Bionator 73

2.2.7 Segunda fase do tratamento - aparelho ortodôntico fixo

2.2.8 Contenção e estabilidade do tratamento com o Bionator 75 



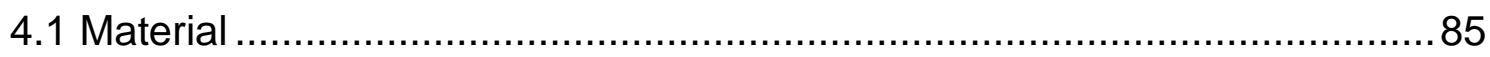

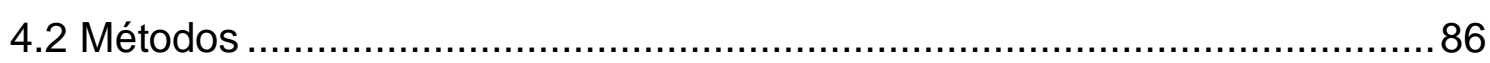

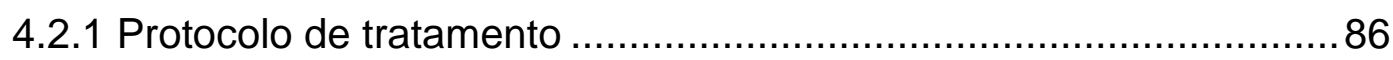

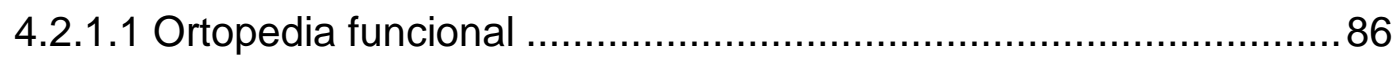

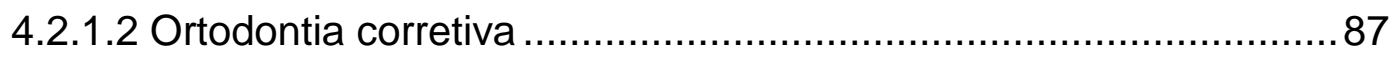

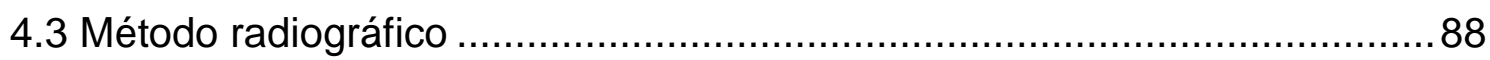

4.3.1 Elaboração do cefalograma e medição das

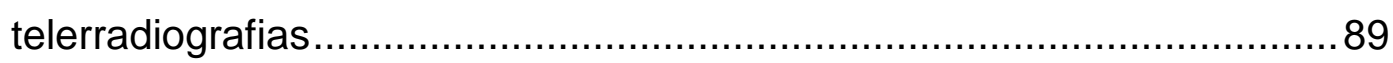

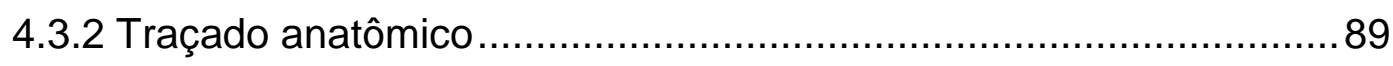

4.3.3 Demarcação dos pontos cefalométricos de

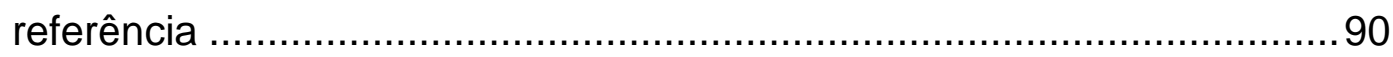

4.3.4 Linhas e planos de referência.....................................................92

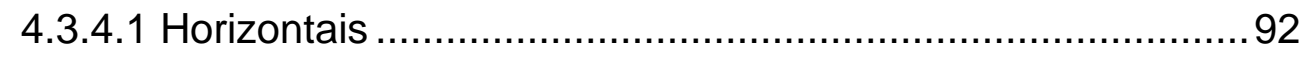

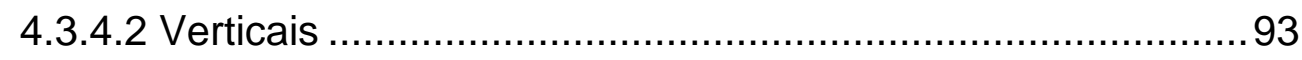

4.3.5 Grandezes cefalométricas esqueléticas ........................................95

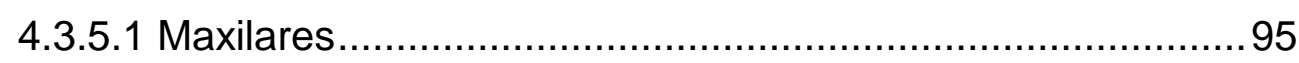

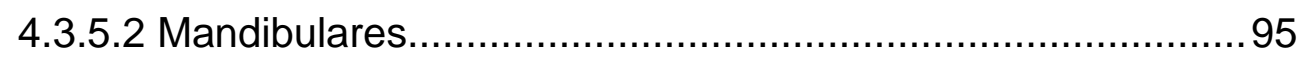

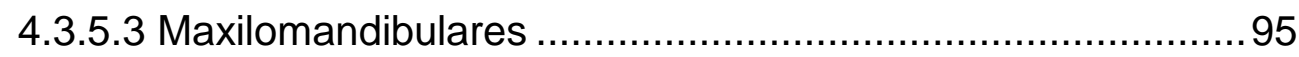

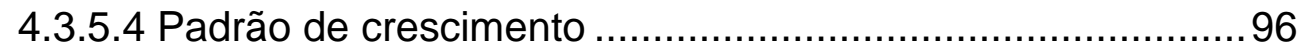

4.3.6 Grandezas cefalométricas dentárias .............................................98

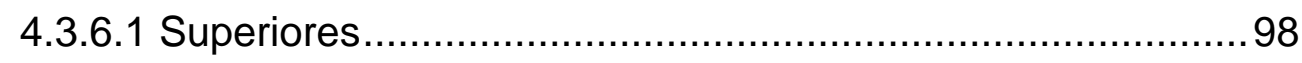

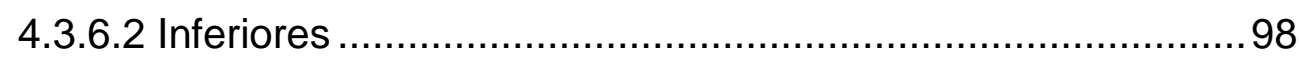

4.3.6.3 Relacionando-os entre si .............................................100

4.3.7 Grandezes cefalométricas referentes ao perfil

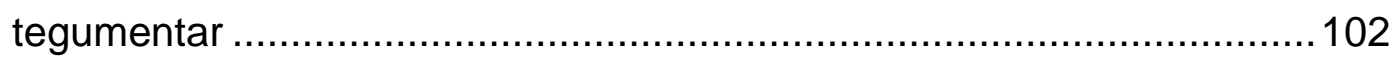

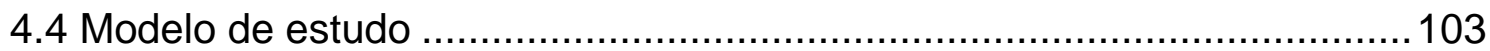

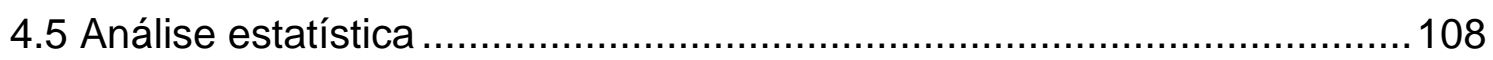

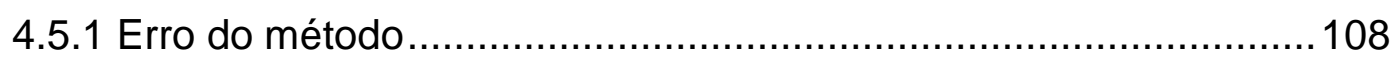

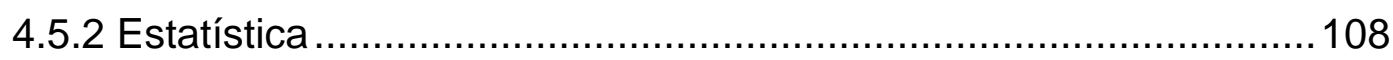



5.1 Análise da normalidade das variáveis............................................. 113

5.2 Resultados do erro intra-examinador .......................................... 113

5.3 Resultados das variáveis cefalométricas ........................................ 115

5.4 Resultados das variáveis de modelo .....................................................116

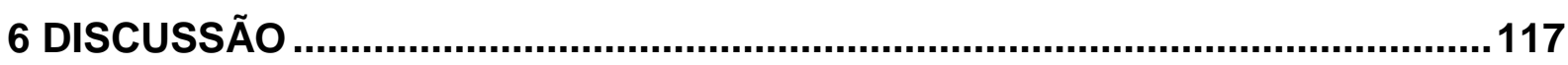

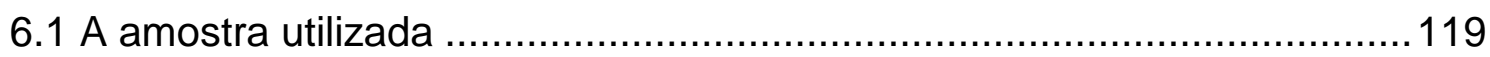

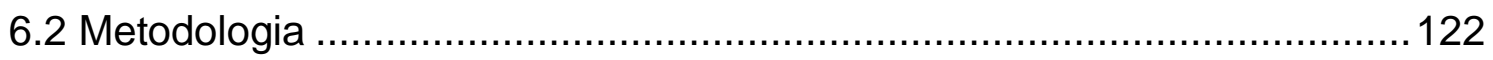

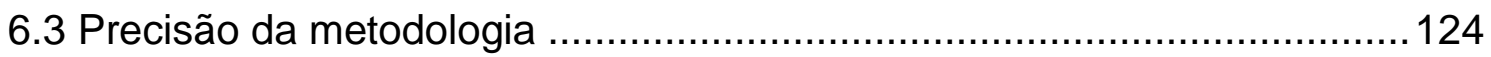

6.4 Resultados cefalométricos .............................................................. 125

6.4.1 Componente maxilar ....................................................... 126

6.4.2 Componente mandibular .................................................... 128

6.4.3 Relação maxilomandibular ............................................... 131

6.4.4 Padrão facial.................................................................. 133

6.4.5 Componente dentoalveolar superior.................................... 137

6.4.6 Componente dentoalveolar inferior....................................... 139

6.4.7 Relações dentárias ............................................................. 142

6.4.8 Tecidos moles ................................................................... 143

6.5 Resultados oclusais ................................................................. 144

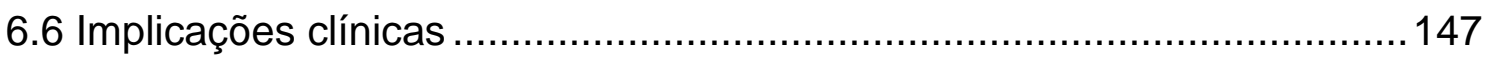

7 CONCLUSÕES ............................................................................................. 151

REFERÊNCIAS........................................................................................ 157

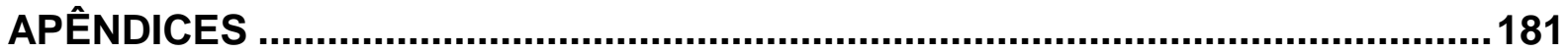



1 Introdução 



\section{INTRODUÇÃO}

São muitos os fatores relacionados com a natureza da má oclusão de Classe II, entre eles podemos citar a estrutura facial, padrão de crescimento maxilar e mandibular e o desenvolvimento dentoalveolar. Essa má oclusão caracteriza-se por um relacionamento deficiente entre os arcos dentários superior e inferior e pode apresentar origem dentoalveolar, esquelética ou uma combinação de ambas (SASSOUNI, 1970). Ela pode estar relacionada a uma protrusão maxilar, a qual pode ser esquelética ou apenas dentária, ou a uma retrusão mandibular e/ou dos dentes inferiores, ou ainda a uma combinação destes fatores (SASSOUNI, 1969). Por tratar-se de uma má oclusão que apresenta aspectos antiestéticos, compromete a harmonia facial em diversos graus, variando com a intensidade da sobressaliência dentária e de sua interação com as estruturas adjacentes de tecidos moles, interferindo, desta maneira, no perfil do paciente (URSI, W.J.S, 1993). São, por conseguinte, facilmente percebidas pelos pacientes e, por isso, grande afluxo destes procuram os profissionais em busca de correções estéticas e funcionais decorrentes desta má oclusão (GURGEL; ALMEIDA; PINZAN, 2001).

Ela, ainda, pode vir acompanhada de uma função anormal dos lábios e de alguma forma de obstrução nasal e respiração bucal (ANGLE, E.H., 1907). Durante o planejamento ortodôntico, as variações individuais desses fatores devem ser levadas em consideração para o correto diagnóstico e plano de tratamento da má oclusão (LAGERSTROM, 1990).

A combinação dos aparelhos ortopédicos funcionais e fixos, para certas categorias de más oclusões, em determinados períodos de desenvolvimento, pode produzir resultados superiores àqueles conseguidos pelo uso de um só tipo de aparelho. Assim, certo discernimento deve ser apresentado pelo ortodontista a fim de que este possa realizar modificações terapêuticas, considerando a multiplicidade de fatores que envolvem uma má oclusão, e para que possa optar pelo tratamento mais adequado para cada caso, em particular, de seus pacientes (GRABER; RAKOSI; PETROVIC, 1997).

Dentre os dois tipos de má oclusão de Classe II, a $1^{\text {a }}$ divisão consiste na mais frequente no consultório ortodôntico (FREITAS, M.R. et al., 2002; GURGEL; 
ALMEIDA; PINZAN, 2001; WEILAND; BANTLEON, 1995) sendo causada, na maioria das vezes, pela retrusão da mandíbula (MCNAMARA, J.A., JR., 1981). Assim, torna-se bem indicada a utilização dos aparelhos ortopédicos funcionais, que redirecionam o crescimento mandibular e atuam durante a fase de crescimento e desenvolvimento craniofacial, propiciando a uma boa oclusão e harmonia do perfil facial (OLIVEIRA JÚNIOR, 2002; OLIVEIRA JÚNIOR JN, 2004). O protocolo de tratamento da Classe II depende da idade do paciente, do comprometimento estético e oclusal. A interceptação desta má oclusão é, ainda, um dos assuntos mais estudados e controversos em função dos diferentes tipos de aparelhos disponíveis e da época ideal para o início do tratamento, destacando-se o tratamento em uma única fase (aparelhos fixos) e em duas fases (aparelhos ortopédicos e fixos). Os aparelhos ortopédicos visam corrigir à discrepância maxilomandibular nos sentidos ântero-posterior e transversal, contribuindo para uma melhora na relação das bases apicais e harmonia do perfil facial. No entanto, o tratamento com aparelhos ortopédicos deve ser indicado para jovens em fase de crescimento e desenvolvimento craniofacial, com a finalidade de alterar espacialmente a forma e 0 posicionamento das bases ósseas, redirecionando o crescimento da maxila e liberando o da mandíbula.

De modo geral, a correção da Classe II, $1^{\text {a }}$ divisão por meio da terapia ortopédica combinada, envolve vários fatores de natureza esquelética e dentária. Entretanto, essas alterações podem ser consideradas satisfatórias somente se permanecerem estáveis. Os estudos de caráter longitudinal demonstram que as alterações alcançadas durante a fase de tratamento ativo tendem a sofrer uma recidiva em direção à má oclusão original nos anos subsequentes ao final do tratamento ortodôntico. O relacionamento dos dentes e das bases ósseas não necessariamente permanece constante ao longo dos anos, mas pode frequentemente ser alterado durante o crescimento. É possível que muitos casos de recidiva ortodôntica representem somente os resultados de um crescimento facial pós-tratamento desfavorável (SINCLAIR; LITTLE, 1985). Além disso, a musculatura bucofacial exerce uma grande influência no desenvolvimento da face e dos dentes. Após a correção da má oclusão de Classe II, a disposição final dos dentes é um reflexo do resultado da interação dos tecidos duros e moles (BASS, 1982). Muitos ortodontistas acreditam que é possível prevenir a recidiva pelo posicionamento dos dentes em harmonia com os lábios, bochechas e língua, pela eliminação de hábitos 
deletérios, por uma contenção adequada e pelo estabelecimento de uma oclusão favorável (GOTTLIEB, 1971).

Apesar dos diversos estudos, os fatores que contribuem para as alterações pós-tratamento ainda não se apresentam claramente definidos. Provavelmente, o impacto do crescimento, em longo prazo, seja fundamental, especialmente, nos tratamentos ortopédicos. Entretanto, a multiplicidade de fatores relacionados à estabilidade e recidiva se relaciona de maneira tão complexa que se torna impossível diferenciá-los (MELROSE; MILLETT, 1998).

$\mathrm{Na}$ disciplina de Ortodontia da Faculdade de Odontologia de Bauru, desde o final da década de 80 , os pacientes que apresentam má oclusão de Classe II, $1^{\text {a }}$ divisão com retrusão mandibular, na fase de crescimento e desenvolvimento, frequentemente são tratados com o Bionator de Balters. Entretanto nenhuma pesquisa avaliando-se a estabilidade desse tipo de tratamento foi realizada.

Portanto, sabendo-se que a estabilidade é a chave fundamental para o sucesso do tratamento ortodôntico, este trabalho se propôs a avaliar os efeitos, limitações e adaptações dentofaciais após um período médio de dez anos de uso desse tipo de terapia seguida da mecânica com aparelho fixo no tratamento da má

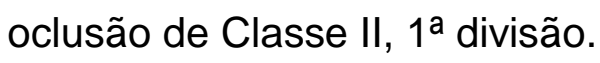





\section{Revisão de Literatura}





\section{REVISÃO DE LITERATURA}

Com a finalidade de facilitar a leitura e a interpretação, dividiu-se a revisão de literatura em partes distintas que abordarão os seguintes tópicos:

2.1 Características da má oclusão de Classe II, $1^{\text {a }}$ divisão;

2.2 Tratamento da má oclusão de Classe II, $1^{\text {a }}$ divisão com ortopedia funcional;

2.3 Tratamento da má oclusão de Classe II, $1^{\text {a }}$ divisão com o Bionator de Balters.

\subsection{A má oclusão de Classe II, 1ª divisão}

Existem várias maneiras de classificação das más oclusões, porém a mais difundida e utilizada pelos Ortodontistas até os dias atuais foi proposta por Angle (1899), no final do século XIX. De acordo com esta classificação, as más oclusões foram categorizadas conforme a relação oclusal apresentada entre o primeiro molar superior e o primeiro molar inferior em Classe I, II ou III. Como o primeiro molar superior era sempre considerado bem posicionado no complexo craniofacial, Angle (1899) caracterizou a má oclusão de Classe II como um relacionamento distal do arco dentário inferior em relação ao superior.

Entretanto, apesar de simples e objetiva, esta classificação considerava apenas as alterações da oclusão no sentido anteroposterior, desprezando as possíveis alterações nos sentidos vertical e transversal. É, também, uma classificação essencialmente dentária, que não correlaciona o mau posicionamento dentário com as estruturas esqueléticas adjacentes. Portanto, o autor definiu a má oclusão de Classe II, 1a divisão, como uma relação mesiodistal deficiente dos arcos dentários, com todos os dentes inferiores ocluindo distalmente em relação ao padrão normal, propiciando a uma desarmonia acentuada dos incisivos e linhas faciais.

Em 1907, o mesmo pesquisador (ANGLE, E.H., 1907) observou que os casos de Classe II, $1^{\text {a }}$ divisão caracterizavam-se por uma relação distal da mandíbula em relação à maxila e, geralmente, com tamanho menor. Ele afirmou também que a 
maxila se apresentava maior que o normal e, frequentemente, atrésica, os incisivos superiores encontravam-se vestibularizados e os inferiores lingualizados. Notou ainda que esta má oclusão geralmente encontrava-se acompanhada de uma função anormal dos lábios e de alguma forma de obstrução nasal e respiração bucal.

Buscando caracterizar a má oclusão de Classe II, Hellman (1922) constatou que a mandíbula se encontrava subdesenvolvida, assim como a maxila.

Lundström, em 1925, após revisar a literatura sobre a natureza da Classe II, observou a existência de um padrão esquelético (hereditário) que dificulta 0 tratamento ortodôntico e de um padrão dentário de fácil tratamento.

Em 1928, as características cefalométricas da Classe II também foram investigadas por Oppenhein e estavam de acordo com o relatado por Hellman (1922). Oppenheim (1936) observou que na maioria das más oclusões de Classe II, ocorre uma falta de desenvolvimento mandibular. Em seu estudo, comparou medidas antropométricas de 18 crânios com características normais e de 18 exibindo má oclusão de Classe II. Concluiu que a Classe II não se caracterizava por um excesso de crescimento para anterior da maxila, verificado pelo ponto Próstio, mas que, na grande maioria dos casos, de distoclusão, este ponto encontra-se posicionado posteriormente. $\mathrm{O}$ autor comentou, ainda, que o tratamento desta má oclusão deveria consistir no estímulo do crescimento e desenvolvimento mandibular.

Defendendo as observações anteriores, em 1941, Baldridge, após um estudo com telerradiografias de jovens de ambos os sexos, com Classe I e Classe II, $1^{\underline{a}}$ e $2^{\underline{a}}$ divisões, verificou que a mandíbula se apresentava em uma relação posterior à face e ao crânio nos casos de Classe II, 1a divisão. Além disso, constatou que a posição do primeiro molar permanente manteve-se constante nas duas amostras, porém sem significado estatístico.

Durante muito tempo, a distoclusão dos molares inferiores foi considerada uma deficiência de crescimento e/ou retroposicionamento da mandíbula. Um dos primeiros autores a discordar desse fato foi Anderson (1946) que demonstrou, ao avaliar casos de Classe II, que, em muitos deles, a mandíbula se apresentava normal, com a maxila posicionada anteriormente, criando uma aparente distoclusão dos molares inferiores. A partir de então, a discordância de dados apresentou-se como uma constante na literatura.

Em 1948, Drelich estudou o padrão facial de 24 jovens com má oclusão de Classe II, $1^{\text {a }}$ divisão e, observou que 0 mento se localizava mais para posterior, a 
base do crânio encontrava-se aumentada e o comprimento da mandíbula diminuído. Afirmou, ainda, que a maioria da amostra apresentou um desenvolvimento insuficiente da altura facial posteroinferior, resultando em um plano mandibular mais inclinado, e que os incisivos superiores se encontravam acentuadamente inclinados para vestibular.

No mesmo ano, estudando uma amostra composta por jovens com más oclusões de Classe I, Classe II, $1^{\text {a }}$ divisão e Classe II, 2ª divisão, Renfroe (1948) comparou as alterações cefalométricas dos 3 grupos. Por meio da avaliação de 95 telerradiografias em norma lateral, concluiu que a mandíbula se encontrava posicionada posteriormente nos jovens com más oclusões de Classe II, $1^{\underline{a}}$ e $2^{\underline{a}}$ divisões; porém verificou que o comprimento mandibular se apresentava similar ao dos jovens com Classe I, dado confirmado por vários autores no decorrer do tempo (BRANDÃO; G.C.; L., 2001; CARTER, 1987; URSI, W.; MCNAMARA, 1997).

Contudo, Nelson e Higley, em 1948, compararam o comprimento do corpo mandibular em 250 jovens, dos 7 aos 14 anos de idade, sendo 153 com oclusão normal e má oclusão de Classe I, e 97 jovens com Classe II, 1a divisão. Por meio das medidas cefalométricas lineares, puderam observar um retrognatismo mandibular acompanhado de um menor comprimento do corpo mandibular nos pacientes com Classe II.

Objetivando caracterizar a má oclusão de Classe II, 1ª divisão, Salzmann, em 1949, relatou diversas variações desta má oclusão, tais como: maxila protruída, retrusão mandibular e, ainda, a combinação destes fatores.

No ano seguinte, Fischer (1950) classificou a má oclusão de Classe II, 1a divisão, em três tipos: dentária, dentofacial e facial.

Gilmore, em 1950, avaliou diversas medidas cefalométricas lineares e angulares de 128 pacientes adultos, de ambos os gêneros, sendo 61 com oclusão normal e 67 com má oclusão de Classe II, 1ํㅡㄹ divisão. Concluiu que as mandíbulas do grupo com Classe II, 1aㅡ divisão apresentavam-se significantemente menores em relação ao grupo de oclusão normal; no entanto, não observou alteração significante na posição anteroposterior da mandíbula, considerando as medidas angulares nos casos de Classe II, $1^{\text {a }}$ divisão.

Com o objetivo de determinar as diferenças existentes entre os padrões esqueléticos faciais da Classe I e Classe II, 1a divisão, Craig, em 1951, comparou um grupo de 34 pacientes Classe I, com 12 anos de idade média, com um grupo de 
33 pacientes Classe II, $1^{\text {a }}$ divisão, com idade média semelhante. Concluiu, por meio de sobreposições, utilizando um sistema gráfico de coordenadas, que ambos os grupos apresentaram um padrão esquelético similar. Porém, o grupo da Classe II, $1^{\text {a }}$ divisão apresentou um menor corpo mandibular, verificado pela distância linear GoGn.

Para verificar a posição espacial da maxila e da mandíbula em relação à base do crânio nos diferentes tipos de má oclusão, Riedel, em 1952, realizou uma pesquisa com telerradiografias. A amostra constituiu-se de 52 adultos com oclusões normais, na faixa etária dos 18 aos 36 anos; 24 jovens com oclusões normais e idades de 7 a 11 anos; 38 casos com Classe II, $1^{1}$ divisão, 10 casos com Classe II, $2^{\text {a }}$ divisão, e 9 com Classe III. Concluiu que as alterações mais significantes se encontravam no posicionamento anteroposterior da mandíbula, avaliado pelo ângulo SNB, e na relação maxilomandibular, quando verificada pelo ângulo ANB. Nos casos de Classe II, $1^{\underline{a}}$ divisão a mandíbula apresentou-se mais retruída em comparação com o grupo de oclusão normal.

Fisk et al. (1953) afirmaram que a má oclusão de Classe II poderia se apresentar em pelo menos seis situações: maxila protruída, dentes superiores protruídos, mandíbula subdesenvolvida, mandíbula com tamanho normal, mas retruída, dentes inferiores retruídos ou qualquer combinação dos fatores anteriormente citados.

Estudando a morfologia facial, Marcondes, em 1955, comparou cefalometricamente um grupo de pacientes com Classe II, 1ㄹ divisão com um grupo controle com oclusão normal. Verificou que a mandíbula no primeiro grupo, denotava um menor tamanho, embora apresentasse uma similaridade com o grupo controle quanto aos componentes das grandezas angulares.

Comparando a morfologia craniofacial de uma amostra de Classe II, $1^{\text {a }}$ divisão com uma de Classe I, Henry, em 1957, propôs uma classificação mais adequada para o primeiro grupo, dividindo-a em quatro tipos: protrusão maxilar alveolar, protrusão maxilar basal, deficiência do tamanho mandibular e retrusão mandibular. Avaliando a posição dos molares permanentes superiores, verificou uma localização mais distal em relação à base do crânio.

Em um estudo sobre as características faciais, Kean (1958), por meio de telerradiografias em norma lateral, utilizou 72 jovens e os dividiu em dois grupos, um com 36 jovens apresentando Classe II, $1^{\text {a }}$ divisão, e outro com 36 jovens com 
oclusão normal, ambos na faixa etária de 8 a 10 anos. Verificou, nos casos com Classe II, que a mandíbula encontrava-se posicionada mais anteriormente em relação ao limite posterior da base craniana, mas apresentava-se com um tamanho menor do que a média, e que o trespasse horizontal acentuado resultava da posição mais para anterior dos incisivos superiores.

Objetivando determinar as relações dentoesqueléticas de 50 jovens com Classe II, $1^{\text {a }}$ divisão, com idades variando de 8 a 15 anos, Maj; Luzi e Lucchee (1960) verificaram que, na maioria dos casos, ocorreu uma desarmonia entre as bases apicais, com um posicionamento anterior da maxila e posterior dos côndilos mandibulares. O comprimento mandibular total, porém, não apresentou grandes variações. Em 78\% dos casos, observaram uma inclinação acentuada para vestibular dos incisivos superiores. Concluíram, deste modo, que a Classe II, $1^{\text {a }}$ divisão resultou de variações dentárias e esqueléticas, com tendência para a protrusão maxilar e um aumento do trespasse horizontal, devido à posição dos dentes anteriores.

Contrariando os resultados de Maj; Luzi e Lucchese (1960), em 1962, King ao comparar amostras de Classe I e Classe II, de adultos de ambos os gêneros, evidenciou que no grupo de Classe II, 1a divisão a mandíbula apresentou-se retrognática em relação à base do crânio, enquanto que os incisivos superiores mostraram uma maior inclinação para vestibular. Analisando a posição espacial da maxila, não encontrou diferença significante entre os dois grupos.

Posteriormente, alguns autores propuseram outros tipos de classificação das más oclusões, ou mesmo, buscaram aprimorar a classificação proposta por Angle (1899). Neste sentido, Ackerman e Proffit, em 1969, observaram que as más oclusões incluídas em uma mesma classificação de Angle poderiam ser análogas, ou seja, poderiam apresentar um relacionamento oclusal semelhante, mas que não necessariamente seriam homólogas, ou seja, com todas as características esqueléticas iguais. Assim, a má oclusão de Classe II pode estar associada a uma ou à combinação das seguintes condições: protrusão maxilar esquelética adicionada ou não a um tamanho maxilar aumentado; protrusão dentária superior; retrusão mandibular esquelética associada ou não a uma mandíbula de tamanho diminuído; retrusão dentária inferior; e ângulo da base do crânio obtuso. De acordo com cada uma dessas condições, exige-se uma forma de intervenção diferente. 
Devido ao fato de a má oclusão de Classe II, 1a divisão apresentar diversos componentes, Sassouni, em 1970, realizou sua subdivisão em 128 tipos diferentes, por meio da análise dos componentes esqueléticos e dentários maxilares e mandibulares, tanto no sentido horizontal como no vertical.

Em 1975, Servoss acrescentou quatro termos à classificação de Angle (1899). Os termos prognatismo ou retrognatismo referem-se ao posicionamento anterior ou posterior, respectivamente, das bases ósseas em relação à base do crânio. Adicionalmente, os termos protrusão ou retrusão descrevem o posicionamento anterior e posterior dos dentes em relação às bases ósseas. Estas condições são distintas, mas podem apresentar-se combinadas. Essencialmente, existem quatro componentes independentes que deveriam ser observados: maxila, mandíbula, dentes superiores e dentes inferiores.

No mesmo ano, Pfeiffer; Grobéty (1975), em um estudo sobre o posicionamento sagital das bases, observaram que a má oclusão de Classe II provém da combinação de alterações dentoesqueléticas, sendo que na maior parte dos casos, a maxila posicionava-se adequadamente e os incisivos superiores apresentavam-se protruídos. No entanto, frequentemente observa-se a retrusão da mandíbula com os incisivos inferiores bem posicionados, ressaltando a necessidade de um diagnóstico adequado para a correção dessa má oclusão.

Para definir a má oclusão de Classe II, Woodside (1980) propôs três tipos: dentoalveolar, esquelética e muscular, e dividiu-a em sete subtipos: 1) face harmoniosa com Classe II dentoesquelética; 2) protrusão do complexo nasofaríngeo e mandíbula bem posicionada; 3) complexo nasofaríngeo normal e mandíbula retruída; 4) complexo nasofaríngeo normal, mandíbula acentuadamente retruída e perfil facial extremamente convexo; 5) complexo nasofaríngeo e maxila protruídos com mandíbula retruída; 6) relação maxilomandibular adequada com obstrução nasal ocasionando retrusão da mandíbula quando em repouso e 7) variação do subtipo 1 com espaço funcional livre muito aumentado.

Ainda em 1980, Moyers et al. utilizaram uma combinação de programas computadorizados para descrever uma série de tipos de Classe II, com características verticais e horizontais bem definidas. Identificaram seis tipos horizontais: uma "Pseudo-classe II" ou Classe II dentária; quatro síndromes de Classe II esqueléticas graves; e um caso moderado de Classe II esquelética, com uma variedade de sintomas. Encontraram, também, cinco tipos verticais, o primeiro 
apresentava o plano mandibular acentuadamente inclinado para baixo; no segundo, os planos mandibular, oclusal e palatino encontravam-se quase paralelos entre si; o terceiro mostrava o plano palatino inclinado para cima; no quarto, os planos mandibular, oclusal e palatino apresentavam-se acentuadamente inclinados para baixo; e no quinto, os planos mandibular e oclusal denotavam normalidade, e o plano palatino encontrava-se inclinado para baixo. Por meio da marcante relação entre os dois padrões, vertical e horizontal, identificaram quinze subtipos com características bem definidas. Ressaltaram que os indivíduos de um mesmo tipo de Classe II, com uma aparência e um padrão de crescimento semelhantes, necessitavam de tratamentos similares e provavelmente deveriam responder da mesma forma.

Com o objetivo de avaliar a frequência com que ocorrem as principais características da Classe II e a abordagem terapêutica mais adequada, McNamara Jr. (1981) analisou telerradiografias em norma lateral de 277 crianças entre 8 e 10 anos. O autor observou que a má oclusão de Classe II pode resultar de várias combinações entre os componentes esqueléticos e dentários. Porém, as características mais prevalentes encontradas em sua amostra foram: posição maxilar retruída ou neutra; dentes anterosuperiores protruídos; retrusão mandibular; dentes anteroinferiores bem posicionados e desenvolvimento vertical excessivo do terço inferior da face.

No ano seguinte, Bass (1982) destacou a grande influência da musculatura bucofacial no desenvolvimento da face e no posicionamento dentário, que gerava, inclusive, alterações no crescimento das estruturas faciais. Avaliando os componentes dentoesqueléticos da má oclusão de Classe II, $1^{1}$ divisão 0 autor observou uma protrusão da maxila e retrusão mandibular ou ainda, em alguns casos, que a maxila se apresentava retruída e a mandíbula acentuadamente retruída.

Em 1987, as características cefalométricas de 50 jovens brasileiros possuindo Classe II, $1^{\underline{a}}$ divisão, com idades variando de 9 a 15 anos, foram analisadas por Vale e Martins. A posição maxilar apresentou-se bastante variável, com discreta tendência ao prognatismo; os incisivos superiores apresentaram-se protruídos; a posição mandibular mostrou-se com grande variabilidade, com maior prevalência do retrognatismo mandibular; os incisivos inferiores apresentaram-se retruídos e houve 
um desenvolvimento vertical excessivo, representado pela altura facial anteroinferior aumentada.

As alterações dentofaciais em jovens com más oclusões de Classe II, 1a divisão, não tratados, foram pesquisadas por Carter em 1987. O autor avaliou estudos cefalométricos que compararam os valores médios para indivíduos com má oclusão de Classe II, 1a divisão com padrões cefalométricos normais. Concluiu que, nos jovens com Classe II, a maxila apresenta-se bem posicionada em relação à base do crânio e a mandíbula, moderadamente retruída, e que os incisivos superiores mostraram-se protruídos, quando comparados com amostras controle. $\mathrm{O}$ autor ressaltou, ainda, que o aumento médio nas dimensões lineares foi quase três vezes maior nos jovens do gênero masculino, quando comparado ao feminino. Não obstante tenha verificado uma considerável variação individual, houve uma maior tendência de redução do trespasse horizontal nos jovens do gênero masculino, não observado no gênero feminino.

Objetivando estudar o comportamento da mandíbula na má oclusão de Classe II, $1^{\text {a }}$ divisão Buschang et al., em 1988, compararam o crescimento deste osso em 42 jovens do gênero feminino e 71 do masculino, dos 6 aos 15 anos de idade, com Classe II, 1a divisão não tratados, com um grupo de jovens possuindo oclusão normal. Os resultados demonstraram um menor crescimento da mandíbula nos pacientes com Classe II. O ângulo SN.Gn, nestes jovens, apresentou um maior aumento, quando comparado com o grupo de oclusão normal, onde a mandíbula exibiu uma rotação no sentido anti-horário.

Em 1993, Proffit buscou caracterizar a má oclusão de Classe II, 1ำ divisão, afirmando que os principais componentes desta má oclusão são acentuados pela deficiência no crescimento mandibular, além de um crescimento maxilar excessivo ou, ainda, por uma combinação dos fatores já mencionados.

Em 1994, Karlsen avaliou a morfologia craniofacial na má oclusão de Classe II, 1a divisão em dois grupos compostos por 24 jovens com mordida aberta e 22 com mordida profunda. Um outro grupo com 25 jovens apresentando oclusão "normal" foi mantido como grupo controle. Os resultados mostraram que os jovens com má oclusão de Classe II apresentavam um comprimento mandibular diminuído e um retrognatismo, caracterizando a principal causa da relação de distoclusão. A altura facial anteroinferior apresentou-se maior nos jovens com mordida aberta, bem como o ângulo do plano mandibular, em comparação ao grupo controle. Nos jovens com 
mordida profunda, a altura facial anteroinferior mostrou-se diminuída, em comparação com o grupo controle.

Rosenblum, em 1995, se propôs a identificar os componentes esqueléticos da má oclusão de Classe II. Para o estudo, o autor utilizou telerradiografias de 103 jovens com má oclusão de Classe II e analisou 4 medidas cefalométricas para avaliação da maxila e outras 4 para avaliação da mandíbula. Os resultados demonstraram uma ampla variedade de protrusão maxilar e retrusão mandibular. De acordo com o ângulo facial de Downs, notou que $27 \%$ da amostra apresentou retrusão mandibular, enquanto que o ângulo NA.FH (linha NA com o plano horizontal de Frankfort) demonstrou uma protrusão maxilar em $56,3 \%$ dos jovens analisados. Assim, concluiu que o padrão predominante destes jovens foi o de protrusão maxilar com uma mandíbula normal.

Pesquisando sobre as associações morfológicas entre as 3 Classes de Angle, Dibbets, em 1996, utilizou uma amostra de 170 jovens avaliados previamente ao início do tratamento. Averiguou que algumas diferenças entre as Classes I, II e III se devem a variações sistemáticas nas dimensões da face média e da base do crânio. O ângulo da base do crânio é mais fechado e as porções anterior (S-N) e posterior (S-Ba) são mais curtas na má oclusão de Classe II. O tamanho mandibular na adolescência não se mostrou diferente entre os grupos. Salientando que a base do crânio propicia condições para o desenvolvimento maxilar, afirmou que a face média é a principal responsável pelas características da Classe II.

Com o desígnio de comparar longitudinalmente as alterações dentofaciais em jovens com Classe II, $1^{\text {a }}$ divisão e jovens com oclusão normal, Bishara et al. (1997), utilizaram dois grupos, os quais foram estudados durante a fase de dentadura decídua até a fase de dentadura permanente. O primeiro grupo constituiu-se de 30 jovens, com Classe II, $1^{\text {a }}$ divisão sendo 15 do gênero masculino e 15 do feminino. $O$ grupo 2 (grupo controle) apresentava 35 jovens, com oclusão normal, sendo 20 do gênero masculino e 15 do gênero feminino. Para a avaliação e comparação dos resultados, foram feitas telerradiografias em norma lateral em três estágios diferentes: dentadura decídua completa (5,5 anos); total irrupção dos primeiros molares permanentes (8 anos); e dentadura permanente completa (12 anos), com exceção dos terceiros molares. Após obterem as grandezas cefalométricas e realizarem a análise estatística, concluíram, por meio da comparação transversal das amostras, que as diferenças no comprimento e na posição da mandíbula entre 
os jovens com Classe II e jovens com oclusão normal, foram significantes no primeiro estágio e não significantes no terceiro estágio. O comprimento mandibular, investigado pela grandeza linear Ar-Pog, encontrava-se diminuído no grupo com Classe II, em ambos os gêneros, quando da comparação com o grupo controle no primeiro estágio. Isto indica que o crescimento mandibular nos jovens com Classe II, $1^{\text {a }}$ divisão pode ocorrer num período mais tardio de desenvolvimento (segundo ou terceiro estágios), alcançando o desenvolvimento normal da mandíbula em jovens com oclusão normal. Notaram, pela comparação longitudinal dos grupos, que 0 padrão de crescimento esquelético-facial não sofre alteração significante, com ressalva da protrusão do lábio superior. A magnitude de crescimento, apontada por diferenças significantes nas grandezas cefalométricas, indicou grandes modificações na convexidade esquelética e facial dos jovens com Classe II, $1^{\text {a }}$ divisão acompanhada por uma tendência à retrusão mandibular. $\mathrm{O}$ crescimento da base do crânio ocorreu similarmente em ambos os grupos, porém nos jovens com Classe II, o ângulo de convexidade esquelética diminuiu com o crescimento, enquanto que 0 ângulo de convexidade facial aumentou.

Baccetti et al., em 1997, acompanhando a mesma linha de pesquisa, utilizaram dois grupos que foram avaliados longitudinalmente (2 anos e 6 meses) desde a fase de dentadura decídua até a fase de dentadura mista. Os grupos constituíam-se de 25 jovens com má oclusão de Classe II e 22 jovens com oclusão "normal". Observaram, então, que a relação de Classe II, apresentada inicialmente, manteve-se ou tornou-se ainda pior durante o período avaliado. O padrão esquelético da Classe II caracterizou-se por uma retrusão mandibular significante, por uma deficiência no comprimento efetivo da mandíbula e por uma rotação deste osso no sentido horário. Por outro lado, a maxila apresentou um crescimento significante para anterior. Os sinais clínicos da má oclusão de Classe II são, portanto, evidentes na dentadura decídua e persistem na dentadura mista.

No mesmo ano, com o propósito de determinar as características de jovens com Classe II, para estabelecer protocolos de tratamentos, Ursi e McNamara Jr. (1997), realizaram um estudo com um grupo de 29 jovens com Classe II e outro grupo de 30 jovens com oclusão normal. Comparando os grupos, verificaram uma semelhança no posicionamento da maxila e uma retrusão mandibular no grupo com Classe II. Quanto aos dentes, os incisivos e molares superiores apresentaram-se 
mais extruídos e os incisivos inferiores mais protruídos e extruídos nos jovens com Classe II.

Para verificar as principais características da má oclusão de Classe II, $1^{\text {a }}$ divisão, Ngan; Byczek; Scheick, em 1997, propuseram um estudo longitudinal das alterações esqueléticas desta má oclusão comparando-a com jovens com Classe I. A amostra constituiu-se de 40 jovens do sexo feminino, entre as idades de 7 e 14 anos, dividida em 2 grupos de 20 jovens cada, sendo um composto por jovens com Classe I e outro por indivíduos com Classe II, 1ª divisão. Analisando os resultados, não houve diferença significante entre os dois grupos na dimensão da base do crânio. A maxila apresentou-se bem posicionada em relação à base do crânio (SNA) nos jovens com Classe II. Entretanto, verificou-se uma retrusão mandibular, avaliada pelos ângulos SNB e SNP, e um comprimento mandibular (Ar-Gn) e do corpo mandibular (Go-Gn) diminuídos quando da comparação entre os grupos. O ângulo do plano mandibular e o eixo "Y" de crescimento encontraram-se aumentados na Classe II, contribuindo para uma retroposição da mandíbula. A relação maxilomandibular (ANB) mostrou-se significantemente maior na amostra de Classe II, aos 7 anos, e se manteve aumentada até a puberdade. Concluindo, os autores sugeriram que o padrão esquelético da Classe II se estabelece precocemente e se mantém até a puberdade, se não submetido à intervenção ortodôntica.

Henriques et al., em 1998, avaliaram longitudinalmente 25 jovens apresentando má oclusão de Classe II, 1ํㅡㄹ divisão, dos 9 aos 12 anos, não tratados. Verificaram que, em $75 \%$ dos casos, a mandíbula apresentou-se retruída, enquanto a maxila variou entre retruída, bem posicionada e protruída. O padrão de crescimento denotou variabilidade, com distribuição uniforme de indivíduos com predominância de crescimento vertical, horizontal e equilíbrio dos vetores. Os incisivos superiores apresentaram-se geralmente protruídos e tenderam a perpetuar esta característica com o crescimento.

Grande parte dos autores (CRAIG, 1951; HENRIQUES et al., 1998; KARLSEN, 1994; MCNAMARA, J.A., JR., 1981; NELSON, B.G., 1953; OPPENHEIM, 1928; URSI, W.; MCNAMARA, 1997) afirma que há uma maior prevalência da retrusão mandibular na má oclusão de Classe II, em detrimento de uma maior protrusão maxilar, como comprovado, mais recentemente, por Bertoz et al. (2003) e Santos (2003). Bertoz et al. (2003) analisaram 55 jovens com má oclusão de Classe II, com idades variando entre 6 e 11 anos. Em 60\% da amostra, a maxila encontrou- 
se bem posicionada ou ainda retruída e a mandíbula apresentou retrusão em relação à base do crânio. Verificou-se, também, que 60 a 70\% dos indivíduos analisados apresentaram crescimento vertical. Os incisivos superiores demonstraram uma tendência excessiva de vestibularização e protrusão, e os inferiores, em cerca de $50 \%$ da amostra, estavam vestibularizados, sendo que na outra metade apresentavam-se bem posicionados e protruídos. Já, Santos (2003) observou em 55 jovens brasileiros, com média de idade de 13,5 anos, e má oclusão de Classe II, que a maxila se encontrava bem posicionada e a mandíbula retruída em relação à base do crânio; a mandíbula apresentava dimensão menor e a maxila normal; o padrão vertical apresentou-se preponderante, e os incisivos superiores e inferiores apresentaram-se inclinados para vestibular.

Porém, outros autores (MAJ; LUZI; LUCCHESE, 1960; ROTHSTEIN, T.; YOON-TARLIE, 2000; ROTHSTEIN, T.L., 1971) concluíram que a Classe II se deveu mais a uma protrusão maxilar do que ao menor tamanho mandibular, que se apresentava normal comparado à oclusão normal. Portanto, observa-se, na literatura, que os resultados pertinentes às características principais da Classe II divergem bastante.

Giuntini et al. (2008), para verificar a posição da fossa glenóide, avaliaram uma amostra de 30 pacientes apresentando uma idade média de 9 anos e má oclusão de Classe II, com retrusão mandibular. As dimensões da mandíbula e das alturas faciais encontravam-se normais. Os autores encontraram a fossa glenóide deslocada para posterior, quando comparada a um grupo controle de oclusão normal.

Sintetizando o tópico a respeito das características morfológicas da má oclusão de Classe II, $1^{\underline{a}}$ divisão, observou-se uma extensa variabilidade dos componentes envolvidos em sua caracterização. Sabe-se que a má oclusão de Classe II tem um envolvimento das bases ósseas no sentido sagital, vertical e transversal, caracterizada, morfologicamente, por uma discrepância maxilomandibular, por um mau relacionamento dos arcos superior e inferior, ou por uma combinação destes fatores. Avaliando-se as alterações sagitais da Classe II, observa-se que esta pode estar relacionada à presença isolada ou à combinação do prognatismo maxilar, do retrognatismo mandibular, com retrusão dos dentes inferiores e protrusão dos superiores, sendo o retrognatismo mandibular considerado como um dos maiores responsáveis por esta má oclusão. Pode também existir uma 
combinação destes fatores com um excesso vertical da maxila ou uma deficiência transversal desta base óssea, denotando a presença de alterações nos três planos: horizontal, vertical e transversal. Mesmo com uma maior tendência a um retrognatismo mandibular, a maioria das pesquisas ressalta a grande variação de apresentações dentárias e esqueléticas. Assim, é imprescindível o conhecimento acerca do crescimento craniofacial e da morfologia da má oclusão a fim de se diagnosticar e instituir um tratamento adequado.

\subsubsection{Tratamento da má oclusão de Classe II, 1' divisão com ortopedia funcional}

A persistência das características oclusais e esqueléticas da má oclusão de Classe II, $1^{\text {a }}$ divisão, desde a dentadura decídua até a permanente, observada por muitos autores (ARYA; SAVARA; THOMAS, 1973; BACCETTI et al., 1997; BISHARA, S.E.; BAYATI; JAKOBSEN, 1996; BISHARA, S. E. et al., 1988; HENRIQUES et al., 1998; NGAN; BYCZEC; SCHEIK, 1997), justifica o planejamento de uma intervenção precoce, embora outros fatores devam ser considerados, como a conduta terapêutica mais adequada a ser instituída e a aceitação e a cooperação do paciente com o tratamento (BACCETTI et al., 1997). Muitos justificam essa intervenção precoce considerando que a correção das alterações da oclusão podem prevenir problemas dentários posteriores, como: aumento da sobremordida e desenvolvimento de apinhamento anterior (HUG, 1982), maior inclinação vestibular dos dentes superiores ou sequelas periodontais (HUG, 1982), injúrias traumáticas devido à inclinação vestibular dos incisivos superiores e ausência de selamento labial passivo (MIGUEL, 2005; O'MULLANE, 1973), além dos aspectos psicológicos envolvidos decorrentes do comprometimento estético, ocasionado pela má oclusão de Classe II, 1를 divisão (GURGEL; ALMEIDA; PINZAN, 2001; HELM; KREIBORG; SOLOW, 1985; KILPELAINEN; PHILLIPS; TULLOCH, 1993; MIGUEL, 2005; PROFFIT; TULLOCH, 2002; URSI, W.; MCNAMARA, 1997) que seriam corrigidos em uma etapa precoce da vida da criança, melhorando sua autoestima (HELM; KREIBORG; SOLOW, 1985; PIERS; HARRIS, 1984). Este problema estético talvez seja a motivação mais importante que leva o paciente a procurar tratamento, principalmente nas sociedades ocidentais, onde a aparência dentofacial exerce um papel fundamental nas interrelações pessoais, já que o público em geral é 
positivamente tendencioso para indivíduos com faces bem proporcionadas (URSI, W.; MCNAMARA, 1997). Além disso, a modificação do crescimento proporcionada pela utilização dos aparelhos funcionais, com a finalidade de corrigir a discrepância entre as bases ósseas, proporcionando uma melhor condição estética a curto e a longo prazo, é o benefício propiciado aos pacientes que fazem uso desses aparelhos e, portanto, tem sido considerada, ao longo dos anos, uma forma de tratamento de grande aceitação pelos ortodontistas na correção da má oclusão de Classe II (BASS, 1983b; CHANG et al., 1989).

Existem evidências de que a fase ortopédica do tratamento proporciona diferenciados benefícios à correção da Classe II (BASS, 1983b; GRABER; RAKOSI; PETROVIC, 1999; LIEBERMAN; GAZIT, 1974; RONDEAU, 1994; YOKOTA; MURAKAMI; SHIMIZU, 1993), principalmente quando há discrepância esquelética advinda da deficiência mandibular, o que pode ser encontrado na maioria dos pacientes com uma relação oclusal de Classe II de moderada a severa (KARLSEN; KROGSTAD, 1999; MCNAMARA, J.A., JR., 1981; PROFFIT; TULLOCH, 2002).

Além disso, os estudos constantes, na literatura (BASS, 1983b; GRABER; RAKOSI; PETROVIC, 1999; LIEBERMAN; GAZIT, 1974; RONDEAU, 1994; YOKOTA; MURAKAMI; SHIMIZU, 1993), concordam que os principais benefícios provenientes da correção da má oclusão de Classe II são alcançados na fase ortopédica do tratamento e compreendem: coordenação do crescimento maxilomandibular (BASS, 1983b; GRABER; RAKOSI; PETROVIC, 1999; RONDEAU, 1994; YOKOTA; MURAKAMI; SHIMIZU, 1993), melhor estética facial subsequente ao tratamento e na fase adulta (BASS, 1983b, 1983a), equilíbrio precoce da musculatura orofacial (BASS, 1983b; LIEBERMAN; GAZIT, 1974; RONDEAU, 1994), garantia de melhor estabilidade da correção em casos mais severos (BASS, 1983b; GRABER; RAKOSI; PETROVIC, 1999), diminuição do percentual de pacientes que necessitam de correção ortodôntico-cirúrgica (BASS, 1983b; RONDEAU, 1994), redução no risco de fraturas e avulsões dos incisivos superiores (BASS, 1983b; GRABER; RAKOSI; PETROVIC, 1999; LIEBERMAN; GAZIT, 1974), menor dependência do crescimento crânio-facial para o sucesso da terapia corretiva, podendo ser iniciada na época mais oportuna para o paciente (BASS, 1983b), alteração imediata da relação sagital pelo aparelho, motivando a cooperação do paciente durante a fase ortopédica e mantendo esta motivação na fase de correção com os aparelhos fixos (BASS, 1983b), redução significativa da necessidade de 
extrações de dentes permanentes para a correção da sobressaliência (BASS, 1983b; GRABER; RAKOSI; PETROVIC, 1999; RONDEAU, 1994; YOKOTA; MURAKAMI; SHIMIZU, 1993), menor quantidade de movimentação dentária na fase corretiva (BASS, 1983b, 1983a), redução do tempo de tratamento com aparelhos fixos, diminuindo seus efeitos indesejáveis (BASS, 1983b; YOKOTA; MURAKAMI; SHIMIZU, 1993) e melhora na autoestima do paciente (LIEBERMAN; GAZIT, 1974; LUEDTKE, 1973).

Em 2005, Miguel et al. também apontaram as principais vantagens e desvantagens da indicação do tratamento precoce da má oclusão de Classe II. Foram citadas como maiores vantagens: aumento da autoestima do paciente, redução da incidência de trauma nos incisivos e menor duração da terapia ortodôntica na segunda fase do tratamento. Por outro lado, a principal desvantagem citada foi a saturação de cooperação do paciente. Além desta, também foram apontadas como desvantagens: incapacidade do paciente em cooperar com o tratamento por falta de maturidade; mínimos benefícios ortopédicos pelo fato do paciente ainda não ter iniciado o surto de crescimento pubescente; aumento do tempo total, bem como do custo do tratamento; menor estabilidade dos resultados obtidos; além dos mesmos resultados poderem ser alcançados em um menor tempo de tratamento.

A utilização de aparelhos funcionais numa fase precoce do desenvolvimento, buscando otimizar o crescimento esquelético da face foi também avaliada por Livieratos e Johnston (1995), que compararam os resultados do tratamento realizado em duas fases (Bionator/Edgewise) com aquele realizado em uma única fase (Edgewise). Ao final do tratamento, as mudanças esqueléticas e dentárias, responsáveis pela correção da relação molar e trespasse horizontal, foram idênticas entre os grupos. Contudo, a magnitude das mudanças, medidas durante o tratamento, diferiu entre os grupos, uma vez que o tratamento realizado em dois estágios iniciou mais cedo e terminou mais tarde, contabilizando cerca de um ano e meio de acréscimo.

Avaliando a duração da fase ortodôntica entre pacientes tratados em uma e em duas fases, Wheeler et al. (2006) observaram que aqueles que se submeteram à primeira fase (ortopédica), finalizaram a segunda (ortodôntica) cerca de 6 meses mais rápido do que aqueles tratados em uma única fase (ortodôntica). Entretanto, ao se considerar o tempo total de tratamento (fase 1 + fase 2 no grupo tratado em 2 
fases; fase 1 naquele tratado em uma única fase), o tratamento em 2 fases mostrouse significantemente mais longo que o tratamento em uma fase (CANÇADO, 2005, 2006; PROFFIT; TULLOCH, 2002; WHEELER et al., 2006). Além disso, ao final do tratamento, os resultados alcançados foram semelhantes para os pacientes tratados em uma fase e aqueles tratados em duas fases (CANÇADO, 2005, 2006; PROFFIT; TULLOCH, 2002; WHEELER et al., 2006). De acordo com Wheeler et al. (2006), em aproximadamente 3 anos de pós-tratamento, não houve diferenças estatisticamente significantes na estabilidade dos resultados do tratamento realizado em uma fase e em duas fases.

Segundo Arvystas, em 1998, o tratamento precoce possibilita a obtenção de uma oclusão normal e de uma harmonia facial e, muitas vezes, os objetivos e limitações da Ortodontia Preventiva e Interceptora não são compreendidos pelos clínicos. O autor numera as principais condições que devem ser tratadas ainda em uma fase precoce: eliminação dos fatores etiológicos que contribuem para a manutenção ou desenvolvimento de uma má oclusão, mordida cruzada nas regiões anterior e posterior, correção das displasias esqueléticas (Classe II e III), e discrepâncias no comprimento dos arcos dentários para evitar a extração de dentes permanentes no futuro. $\mathrm{O}$ autor considera que os maiores aliados dos ortodontistas em um tratamento precoce são o crescimento e o tempo.

Avaliando a efetividade do tratamento da má oclusão de Classe II, em função da época em que o tratamento se inicia, Von Bremen e Pancherz, em 2002, realizaram um estudo retrospectivo em modelos de gesso de 204 pacientes. A efetividade do tratamento foi definida como um melhor resultado oclusal em um menor período de tempo. A metodologia utilizada nos modelos de gesso foi o índice PAR. Os resultados mostraram que os pacientes tratados exclusivamente com aparelhos fixos tiveram um menor tempo de tratamento quando comparados àqueles tratados com aparelhos funcionais ou uma combinação de funcional e fixo convencional. Os pacientes tratados exclusivamente com aparelho fixo apresentaram uma maior redução do índice PAR (77\%) com o tratamento. Com base nestes resultados, os autores concluíram que o tratamento da Classe II apresenta maior efetividade ao iniciar-se na dentadura permanente do que aqueles que se iniciaram na dentadura mista.

Pfeiffer e Grobety, em 1975, mostraram a importância do diagnóstico diferencial e a grande efetividade dos aparelhos ortopédicos no tratamento das más 
oclusões de Classe II. Concluíram os autores que, em muitos casos tratados com aparelhos ortopédicos, a necessidade da realização de uma segunda fase com aparelhos fixos era menor e haveria um aumento da estabilidade em longo prazo.

Em 1989, Bishara e Ziaja compulsaram extensamente a literatura pertinente ao tratamento das más oclusões de Classe II, 1ำ divisão com os ativadores, os reguladores de função e os aparelhos fixos, segundo o mecanismo de ação, bem como a efetividade destes aparelhos. Após a pesquisa bibliográfica, ressaltaram que: o aparelho funcional é apenas uma das modalidades efetivas no tratamento da Classe II; os casos de Classe II, 1a divisão ideais para a utilização de aparelhos funcionais seriam aqueles em que os pacientes se encontrassem na fase de crescimento, nos quais as extrações dentárias prejudicariam a estética facial, com os incisivos superiores protruídos e inferiores retruídos, com trespasse vertical acentuado, e com uma inclinação do plano mandibular de média a plana, e retrusão mandibular esquelética; o sucesso do tratamento ortopédico depende da cooperação do paciente e da sua duração nos períodos de crescimento craniofacial; os aparelhos ortopédicos devem ser utilizados por um período de tempo prolongado, geralmente de um ano e meio a dois anos, para assegurar uma completa adaptação condilar após o deslocamento inicial na cavidade glenóide; e a despeito do tipo de aparelho funcional utilizado, afirmaram que a correção da má oclusão ocorreria de maneira semelhante, ou seja, estimulando o crescimento mandibular, redirecionando o crescimento maxilar, inclinando os incisivos superiores para lingual, vestibularizando os incisivos inferiores, bem como promovendo uma erupção mesial e vertical dos molares inferiores e inibindo a erupção mesial dos molares superiores.

Com o objetivo de avaliar a estabilidade em longo prazo do tratamento da má oclusão de Classe II em duas fases utilizando o índice PAR, Mcknight, Daniels e Johnston, em 1998, avaliaram modelos de gesso de 27 pacientes que haviam terminado o tratamento após um período médio de 9 anos. Concluíram que a maior alteração no índice PAR ocorreu durante a primeira fase do tratamento com aparelhos funcionais e que ao término da segunda fase com aparelhos fixos, havia uma redução média de $83 \%$ no índice PAR. Em relação à estabilidade, verificou-se que o índice PAR aumentou significantemente após o término do tratamento devido principalmente à recidiva do trespasse horizontal e do apinhamento na região anteroinferior. 
O tratamento da Classe II, quando realizado em duas fases: uma ortopédica e outra ortodôntica, apresenta uma maior estabilidade do que quando realizado em apenas uma fase com aparelhos fixos (STARNES, 1991). Segundo Pavlow et al., em 2008, os fatores mais significativos e determinantes de uma maior estabilidade são determinados por meio do valor do índice PAR ao final do tratamento, e também estão relacionados ao início da segunda fase, sugerindo que os indivíduos que iniciaram um tratamento precoce, com redução da pontuação do índice PAR, poderiam ter maior estabilidade.

Portanto, o fato de que os aparelhos ortopédicos promovem alterações esqueléticas nos maxilares que contribuem para a correção das más oclusões, sobretudo da má oclusão de Classe II, encontra-se bem estabelecido e fundamentado na literatura vigente (ALMEIDA-PEDRIN, 2003; ALMEIDA, M.R., 2000a; BALTROMEJUS; RUF; PANCHERZ, 2002; BASS, 1983b; BRANGELI, 2000; CANGIALOSI et al., 1988; DE ALMEIDA; HENRIQUES; URSI, 2002; DEVINCENZO, 1991; FALTIN, K.J. et al., 2003; FISCHER, 1950; HARALABAKIS; HALAZONETIS; SIFAKAKIS, 2003; PANCHERZ; FISCHER, 2003; RABIE; SHE; HAGG, 2003a; VOUDOURIS; KUFTINEC, 2000; VOUDOURIS et al., 2003a; VOUDOURIS et al., 2003b; WIESLANDER, 1993; WOODSIDE, 1998). Entretanto, as modificações no complexo côndilo-fossa, favoráveis à correção da má oclusão de Classe II e observadas por diversos autores (VOUDOURIS et al., 2003a; VOUDOURIS et al., 2003b, BALTROMEJUS; RUF; PANCHERZ, 2002; PANCHERZ; FISCHER, 2003, RABIE; WONG; TSAI, 2003b) são válidas apenas enquanto o aparelho está sendo utilizado. Após o tratamento ortopédico, tanto as alterações qualitativas quanto as quantitativas, induzidas no crescimento, tendem a retornar aos parâmetros prétratamento. Pancherz, em 2003, relatou que o período pós-tratamento foi acompanhado por uma menor quantidade de crescimento e por um retorno à direção de crescimento condilar mais vertical, semelhante àquela presente no período prétratamento. O remodelamento da fossa, que no período de tratamento foi redirecionado para anterior, retornou à direção posterior no período pós-tratamento.

A reversão dos efeitos do tratamento foi também observada por Voudouris e Kuftinec em 2000. Na analogia feita pelos autores, a remodelação do côndilo e da fossa sob a ação dos aparelhos funcionais assemelha-se a uma lâmpada num reostato. A transdução dos estímulos mecânicos gerados pelos aparelhos funcionais ao côndilo e à fossa articular intensifica a remodelação óssea que ocorre nesta 
região. Contudo, uma vez removido o estímulo mecânico ao final do tratamento, a remodelação vai diminuindo em intensidade, até atingir um nível basal. Além disso, os autores afirmaram que o retorno do côndilo à fossa e a restituição da função muscular ao final do tratamento, sobretudo do digástrico anterior, gera um maior nível de compressão nesta região, determinando um alto grau de recidiva das mudanças (VOUDOURIS et al., 2003a). Sendo assim, o restrito tempo de tratamento associado à recidiva pós-tratamento faz com que nenhuma quantidade clinicamente significante de tecido ósseo adicional esteja presente em longo prazo.

\subsubsection{Estabilidade do tratamento da má oclusão de Classe II, $1^{\text {a }}$ divisão com ortopedia funcional}

Para Angle, em 1907, a correção ortodôntica permanecia estável se os dentes fossem alinhados e corrigidos para uma oclusão normal, recebendo uma adequada contenção e uma função mastigatória vigorosa. Entretanto, os ortodontistas têm observado que os resultados dos tratamentos são susceptíveis às alterações, pelo menos semelhantes, das oclusões normais, e que há certamente limitações na estabilidade em longo prazo das relações corrigidas (PROFFIT, 1994).

A movimentação dentária está relacionada com a reorganização do ligamento periodontal no osso alveolar. Durante a contenção, as fibras estiradas tendem a tornar-se funcionalmente organizadas e um novo osso irá preencher o espaço entre as espículas ósseas, o qual irá resultar em um osso bastante denso, que vai prevenir, durante um certo período, as recidivas da movimentação dentária. Durante a contenção, as fibras do ligamento periodontal tendem a se tornar menos estendidas e ficam afrouxadas e reorganizadas (THILANDER, 2000b). Entretanto, a maior parte dos estudos indica que é difícil salientar um único fator relacionado à recidiva, e que esta é um problema multifatorial. Os fatores envolvidos podem estar relacionados com o crescimento craniofacial, com o desenvolvimento dentário e com a função muscular (THILANDER, 2000a). Estes processos são genética e ambientalmente condicionados e continuam a mudar ao longo da vida, mostrando uma grande variação individual. Assim, a oclusão deve ser considerada como uma inter-relação dinâmica entre estruturas faciais (THILANDER, 2000b).

O crescimento ocorre em taxas diferentes e em diversas direções do espaço. A elevada variabilidade do crescimento foi demonstrada por Björk, em 1968, em um 
de seus primeiros estudos descrevendo 0 uso de implantes metálicos em cefalometria. Os estudos antropométricos de dimensões craniofaciais demonstraram que significativas mudanças ocorrem nos seres humanos, mesmo na idade adulta (JANSON, G.R.P. et al., 2001). Entretanto, mudanças do crescimento tardio podem ser responsáveis pela recidiva, especialmente depois da correção de más oclusões (THILANDER, 2000a).

Kahl-Nieke, Fischbach e Schwarze, em 1995, realizaram um estudo longitudinal entre 10 a 25 anos após o tratamento ortodôntico, e demonstraram que os pacientes com uma boa intercuspidação dos molares desenvolviam uma pequena tendência à recidiva, quando comparados àqueles que finalizavam com uma relação de Classe II ou III. Salientaram, ainda, que as alterações pós-tratamento deveriam ser sempre monitoradas, uma vez que ocorreram por meio da força, e não pela função natural.

Reidel, em 1960, publicou uma série de teoremas, baseados em sua experiência clínica. Dentre eles estão: todo dente apresenta uma tendência à recidiva; a eliminação da causa da má oclusão ajuda a evitar a recidiva; a sobrecorreção da má oclusão deve ser encarada como um fator de segurança; a oclusão correta constitui um fator importante para a estabilidade; o osso e os tecidos adjacentes necessitam de um período de tempo para se reorganizarem após a correção; correções realizadas durante o período de crescimento estão menos sujeitas à recidiva; e, quanto maior a distância do movimento dentário, menor a recidiva. Ressaltou ainda que, apesar de o crescimento representar um fator relevante na correção de diversos tipos de má oclusão, este pode causar recidiva nos pacientes já tratados. Afirmou, também, que uma contenção mais prolongada pode proporcionar uma estabilidade razoável.

Ormiston et al., em 2005, concluíram, em estudo realizado em modelos com o índice PAR, que a severidade inicial da má oclusão se correlacionou com a estabilidade pós-contenção, ou seja, que pacientes com índices mais severos antes do tratamento apresentaram uma tendência de ser menos estáveis na fase póscontenção. Birkeland et al., em 1997, avaliaram o resultado do tratamento ortodôntico em casos tratados com más oclusões de Classe I, II e III, por meio do índice PAR, observando, dentre os resultados, que pacientes com más oclusões mais severas antes do tratamento tendem a apresentar maior recidiva póscontenção. 
Little, Reidel e Artun, em 1988, e posteriormente Little, em 1999, relataram que, por mais de 40 anos, o Departamento de Ortodontia da Universidade de Washington, em Seattle, se concentrou na coleta de mais de 800 conjuntos de exames de pacientes para verificar a estabilidade e a recidiva no tratamento ortodôntico. Todos os pacientes avaliados haviam completado o tratamento ortodôntico há aproximadamente uma década. Segundo o autor, as extrações de pré-molares, a fim de permitir o alinhamento dos dentes apinhados, tem sido um procedimento aceito por décadas e continua sendo um tratamento bastante indicado para pacientes com arcos apinhados. Apesar da busca em se alcançarem as normas cefalométricas sugeridas e aderindo-se aos padrões clínicos usuais de forma do arco, trespasse vertical, entre outros, a manutenção em longo prazo de resultados aceitáveis é desapontadora, com apenas 30\% dos pacientes mostrando resultados aceitáveis. O uso indefinido de contenções fixas ou removíveis, provavelmente para a vida toda, parece ser o único recurso lógico.

Alguns princípios foram estabelecidos por Reitan, em 1969, para minimizar a recidiva. A sobrecorreção, a verticalização dos dentes anteriores e a preservação das distâncias interdentárias iniciais dos pacientes seriam procedimentos importantes no tratamento ortodôntico, pois aumentariam a estabilidade.

Melrose e Millett, em 1998, realizaram uma revisão de literatura sobre estabilidade e recidiva, e afirmaram, dentre outras coisas, que uma boa intercuspidação oclusal previne a migração dos dentes e uma relação molar de Classe I pode ajudar na estabilidade (HARRIS; BEHRENTS, 1988), apesar de não haver uma garantia porque 0 crescimento pós-tratamento pode alterar significantemente a relação molar anteroposterior. A correção de uma Classe II para uma relação molar de Classe I pode ter um efeito benéfico no crescimento, promovendo a manutenção da relação molar. Além disso, afirmaram que a sobrecorreção da relação oclusal como procedimento de finalização tem sido recomendada para controlar a recidiva da Classe II (SOUTHARD; BEHRENTS; TOLLEY, 1989).

Normalmente, os tratamentos ortodônticos são longos e empregam técnicas complexas, alcançando muitas vezes resultados admiráveis; embora possam se perder em graus variados após a remoção dos aparelhos. A recidiva ortodôntica inclui o apinhamento ou o espaçamento dos dentes, a recidiva da expansão rápida da maxila, o retorno de trespasses horizontal e vertical aumentados, e a estabilidade 
das correções da relação molar de Classe II e Classe III (THILANDER, 2000b). Considerando-se que o paciente que possui uma má oclusão de Classe II, 1a divisão pode, geralmente, apresentar uma associação de alterações dentárias, musculares, ósseas e nervosas, torna-se necessário o restabelecimento da harmonia entre todos esses sistemas para se obter estabilidade dos resultados do tratamento.

Weiland, em 1994, realizou um estudo que tinha por finalidade verificar a influência das discrepâncias oclusais na estabilidade em longo prazo do tratamento ortodôntico. Os modelos de estudo e os registros cefalométricos de 40 pacientes (9 Classe I, 24 Classe II, $1^{\text {a }}$ divisão e 7 Classe II, $2^{\underline{a}}$ divisão) foram avaliados antes do início do tratamento, ao final e pelo menos 9 anos após a remoção da contenção. Como resultado, verificou-se que a largura e o comprimento do arco diminuíram significativamente após a contenção. A posição dos incisivos inferiores permaneceu relativamente estável, enquanto a dos molares inferiores se moveu substancialmente para frente. A irregularidade anteroinferior aumentou após o tratamento, e 60\% dos casos apresentaram um alinhamento insatisfatório. A quantidade de deslize mandibular diminuiu com o tempo e teve uma influência estatisticamente significante, embora clinicamente apenas moderada no aumento da irregularidade anteroinferior, ou seja, contribuiu com apenas $15 \%$ da variação na irregularidade. Os molares inferiores, que se moveram para frente durante e após o tratamento, foram responsáveis pela diminuição do comprimento do arco. Os autores afirmaram que, para melhorar a estabilidade, deve-se manter a menor distância possível entre a relação cêntrica e a máxima intercuspidação habitual, e ótimas relações oclusais devem ser obtidas ao final do tratamento.

Falhas no reconhecimento da influência contínua do crescimento sobre as estruturas dentofaciais, após o tratamento ter-se completado, e seus efeitos favoráveis ou desfavoráveis na fisionomia e no relacionamento dentário, podem comprometer a estabilidade, em longo prazo, dos resultados obtidos durante 0 tratamento ortodôntico (NANDA; NANDA, 1992). Contudo os clínicos não têm dado a devida atenção às alterações decorrentes do crescimento normal na fase póstratamento. De acordo com Nanda e Nanda, em 1992, os ortodontistas atentam-se mais às relações dentárias durante o tratamento, deixando a relação esquelética em segundo plano, pois quando os dentes assumem uma boa intercuspidação, geralmente, finaliza-se o tratamento ortodôntico. Além disso, os clínicos consideram que não há nada a fazer durante a fase pós-tratamento para modificar o padrão de 
crescimento. O grande problema é que a maior parte dos pacientes termina seus tratamentos ortodônticos antes ou durante o surto de crescimento. O crescimento facial é importantíssimo durante a correção de muitos problemas ortodônticos, mas esse mesmo fenômeno pode acarretar em recidivas na fase pós-contenção. Segundo os autores, torna-se extremamente importante reconhecer o padrão de crescimento de cada paciente para planejar tanto o tratamento ortodôntico como o aparelho de contenção. Portanto, a natureza e a duração da contenção devem basear-se no estágio de maturação de cada paciente e em seu padrão de crescimento.

Avaliando a influência do tratamento ortopédico da Classe II, 1a divisão sobre a direção de crescimento mandibular durante o tratamento e 2 anos imediatamente após a finalização do mesmo, Mair e Hunter, em 1992, observaram que o tratamento provoca a interrupção do padrão de crescimento normal em ambos os períodos. $O$ crescimento mandibular apresentou-se mais vertical nos pacientes tratados com 0 Bionator em relação ao grupo controle, durante o tratamento. Por outro lado, a direção de crescimento pós-tratamento foi mais horizontal do que durante 0 tratamento, e a intensidade do vetor horizontal apresentou-se extremamente variável. Além disso, a direção de crescimento pós-tratamento não foi significantemente correlacionada à direção de crescimento durante o tratamento.

Binda et al., em 1994, analisaram as alterações pós-contenção de variáveis esqueléticas, dentárias e de tecido mole na má oclusão de Classe II, $2^{a}$ divisão, independentemente do tipo de tratamento. Os pacientes foram avaliados ao início e ao final do tratamento, e em 2 e 5 anos de pós-contenção. Observou-se que muitas das alterações que ocorreram nesses períodos foram consequências do crescimento mandibular natural e das adaptações das alterações induzidas pelo tratamento e que todas as medidas apresentaram alterações significantes, principalmente, nos dois primeiros anos após o término do tratamento. A recidiva da sobremordida encontrase relacionada à recidiva da inclinação dos incisivos superiores que ocorre nesse tipo de má oclusão. As alterações com o tempo foram maiores para os pacientes do gênero masculino do que para o feminino, sendo também, menores para os grupos com idades mais avançadas. Durante o tratamento, o ângulo interincisivo e a sobremordida diminuíram e, na fase pós-contenção, ambos aumentaram significantemente. Os autores não avaliaram a estabilidade da relação molar. 
Otuyemi e Jones, em 1995, utilizaram o índice PAR para avaliar o tratamento e os resultados pós-contenção, em longo prazo, de 50 casos de má oclusão de Classe II, $1^{\text {a }}$ divisão. Foram empregados os modelos de estudo para registro da oclusão pré, pós-tratamento, 1 ano pós-tratamento e 10 anos pós-tratamento, estando esta última avaliação sem contenções. Os resultados sugeriram um tratamento ortodôntico de alto padrão, indicado pela porcentagem média de redução do índice PAR. Entretanto, a manutenção dos resultados pós-tratamento, após $1 \mathrm{e}$ 10 anos pós-contenção, apenas foi alcançada em 60 e $38 \%$ dos casos, respectivamente. O principal fator envolvido nessa deterioração foi relatado como sendo o apinhamento anteroinferior. Concluíram que, apesar de uma má oclusão de Classe II tratada com sucesso aparentemente apresentar uma tendência a deteriorar após o tratamento, muito desse resultado ocorreu devido à recidiva do apinhamento anteroinferior.

Elms, Buschang e Alexander, em 1996, avaliaram em modelos de gesso a estabilidade do tratamento da má oclusão de Classe II desenvolvido em 42 pacientes com o aparelho fixo associado ao extrabucal e que apresentaram bons resultados ao término do mesmo. Foi observado um aumento de $0,5 \mathrm{~mm}$ no trespasse horizontal e de $0,4 \mathrm{~mm}$ no trespasse vertical. $O$ índice de irregularidade dos incisivos inferiores aumentou apenas $0,4 \mathrm{~mm}$ depois do tratamento. Os autores concluíram que as ações com vistas à solução da má oclusão de Classe II sem extração mostraram-se altamente estáveis. Logo depois, os próprios autores, publicaram a avaliação cefalométrica dos mesmos pacientes citados na pesquisa anterior. Os resultados demonstraram que 0 ângulo ANB diminuiu $2^{\circ}$ durante $O$ tratamento, devendo-se isso, possivelmente, à diminuição do ângulo SNA, que foi de $1,6^{\circ}$. O molar inferior inclinou-se $4^{\circ}$ para trás. El es afirmaram que, de acordo com seus resultados, a cada $3^{\circ}$ de inclinação do molar p ara trás, havia cerca de $1^{\circ}$ de recidiva dessa inclinação.

Muito se discute, na literatura, quanto às diferenças em relação aos incrementos de crescimento e às diferenças no tamanho dos componentes faciais entre jovens do gênero masculino e feminino. Desse modo, Bishara; Jakobsen e Angelakis, em 1996, tentaram determinar se as alterações pós-tratamento em jovens com Classe II, $1^{\underline{a}}$ divisão expressam tendências similares entre o gênero masculino e feminino. Uma amostra com oclusão normal também foi avaliada e comparada ao grupo com Classe II. Observaram que existem várias diferenças significantes quanto 
ao tamanho e aos incrementos de crescimento (S-N, S-O, N-O, N-ENA, N-Me, Ar-Go e S-Go) entre o gênero masculino e feminino. Entretanto, os gêneros masculino e feminino demonstraram tendências similares em direção às alterações póstratamento, indicando que não se deve esperar diferenças significantes nas tendências pós-tratamento baseando-se no gênero do paciente.

Woods, Lee e Crawford, em 2000, realizaram uma pesquisa com modelos de estudo de 65 pacientes nos estágios pré, pós-tratamento e pelo menos 6,5 anos após a remoção de todos os aparelhos de contenção. Não especificaram o tipo de má oclusão dos pacientes. O método de avaliação da oclusão foi o índice PAR, calculado nos modelos de cada paciente, nos três estágios avaliados. Calculou-se a média do índice PAR da amostra total e para cada subgrupo, além da porcentagem média de alteração do índice PAR entre as fases estudadas. O índice PAR sofreu uma redução de $85,6 \%$ com o tratamento e teve um aumento de $15,2 \%$ no período pós-contenção. Os autores afirmaram que nem todas as alterações oclusais são negativas e, em alguns casos, é mesmo possível que ocorra uma considerável melhora oclusal durante ou após o tratamento. Concluíram que nem o índice PAR ao final do tratamento, nem a quantidade de alterações oclusais ocorridas durante ou após o tratamento possibilitaram a previsão da quantidade ou do tipo de alteração oclusal em longo prazo.

Janson et al., em 2004, avaliaram cefalometricamente a estabilidade das alterações do tratamento com o aparelho extrabucal conjugado ao Ativador seguido de aparelhos fixos, após um período médio de 5 anos. Os resultados demonstraram uma estabilidade em longo prazo das alterações dentoalveolares anteroposteriores. Semelhantemente, as posições anteroposteriores da maxila e da mandíbula não exibiram recidiva no período pós-tratamento. Entretanto, houve ligeira recidiva da correção da relação maxilomandibular, provavelmente por ter a maxila retomado o seu desenvolvimento normal e a mandíbula ter apresentado uma velocidade de crescimento significantemente inferior ao grupo controle. O trespasse vertical revelou uma recidiva estatisticamente significante e diretamente proporcional à quantidade de sua correção. Além disso, a avaliação individual dos pacientes, baseada na relação molar, demonstrou uma recidiva em 13,05\% dos casos. Essa recidiva mostrou-se relacionada à rotação horária da mandíbula, à redução do ângulo SNB e ao aumento de Co-A, todos significantes, no período pós-tratamento. 
Ciger, Aksu e Germec, em 2005, estudaram as alterações pós-tratamento e pós-contenção de 18 pacientes com má oclusão de Classe II, $1^{a}$ divisão, tratados com AEB cervical e aparelhos fixos e sem extrações. Foram avaliados os modelos e os cefalogramas, em média 5,3 anos pós-contenção. Os resultados pós-contenção demonstraram que a maxila permaneceu estável, a mandíbula se moveu para anterior, e o trespasse horizontal aumentou suavemente (em média 1,25 mm). Com relação às variáveis estudadas nos modelos, os índices de irregularidade superior e inferior diminuíram com 0 tratamento e aumentaram após a remoção das contenções.

Enfim, o ortodontista deve saber diferenciar as alterações pós-tratamento atribuídas à instabilidade dentária e ao crescimento. O paciente ortodôntico adolescente convencional é tratado durante uma fase de crescimento ativo, porém o crescimento do complexo dentoesquelético continua após o tratamento até a idade adulta com uma velocidade bastante lenta. Baseando-se nisso, Gardner; Harris e Vaden, em 1998, avaliaram 36 pacientes tratados com a mecânica "edgewise" convencional e extração de pré-molares. Esses pacientes foram avaliados em 2 estágios equivalentes a 5,5 anos e 14,4 anos pós-tratamento (22 e 30 anos respectivamente). Observaram alterações consideráveis na posição dentária, entretanto a maioria delas ocorreu devido ao crescimento. Até a primeira avaliação, observou-se um movimento para mesial dos primeiros molares superiores, o qual foi atribuído ao crescimento maxilar. Esse movimento contribuiu para uma suave recidiva da relação molar de Classe II. Além disso, os incisivos superiores movimentaram-se em direção anterior e extruíram pelo mesmo motivo, ou seja, devido ao crescimento maxilar e do terço médio da face. Também foi observada uma extrusão dos molares superiores em decorrência do crescimento do osso alveolar. $O$ ângulo FMIA aumentou $1,5^{\circ}$, fato esse atribuído à di minuição do ângulo FMA, uma vez que o IMPA permaneceu inalterado indicando que a inclinação dos incisivos inferiores permaneceu constante. Todavia a rotação da mandíbula contribuiu para a alteração do FMIA. A extrusão verificada nos molares inferiores deveu-se à remodelação da borda inferior da mandíbula, ao nivelamento da curva de Spee e à acomodação alveolar ao crescimento condilar. A maior parte dessas alterações foi avaliada durante o primeiro estágio pós-tratamento, ou seja, até os 22 anos de idade. Muitas das variáveis estudadas permaneceram estáveis e a maturação do 
crescimento craniofacial foi responsável, em grande parte, pelas variáveis que exibiram uma recidiva.

Nesse mesmo contexto, no ano seguinte, Siqueira et al. (1999) realizaram um estudo cefalométrico longitudinal, propondo verificar a influência do crescimento craniofacial sobre a recidiva do trespasse horizontal. Para isso, foram utilizadas telerradiografias em norma lateral ao início, final e cinco anos após o tratamento ortodôntico de 48 jovens que apresentavam, inicialmente, má oclusão de Classe II, $1^{\text {a }}$ divisão e que se submeteram a extrações dos quatro primeiros pré-molares. Analisando-se os valores de Co-A e de ENA-ENP, observaram que todos os pacientes apresentaram restrição do crescimento maxilar durante o tratamento ortodôntico, porém ocorreu um aumento dessas variáveis do final do tratamento até 5 anos após, sendo maior para os meninos do que para as meninas. Os valores de Co-A mostraram diferenças estatisticamente significantes, indicando ser um fator de risco para a recidiva. As meninas apresentaram incrementos mandibulares menores do que os meninos nos dois períodos analisados, mas esse fato não demonstrou influenciar significantemente a recidiva da sobressaliência. O ângulo SNA apresentou uma acentuada restrição durante o tratamento ortodôntico, mas 5 anos depois ocorreu um suave aumento em todos os pacientes. O ângulo SNB diminuiu suavemente na maioria dos pacientes, mas 5 anos depois observou-se que os pacientes do gênero masculino apresentaram incrementos maiores do que o gênero feminino. Além disso, a alteração dos ângulos SN.GoGn e FMA não demonstraram influenciar significantemente a recidiva do trespasse horizontal. Porém constataram que alterações nos ângulos SN.PP e PP.GoGn constituem fatores de risco para a recidiva da sobressaliência. 


\subsection{Tratamento da má oclusão de Classe II, 1ª divisão com o Bionator de Balters}

\subsubsection{O desenvolvimento do aparelho Bionator e a filosofia de Balters}

O Bionator consiste em um aparelho funcional derivado do Ativador de Andresen, que foi desenvolvido na década de cinquenta pelo médico alemão Wilhelm Balters (BALTERS, 1969; GRABER; NEUMANN, 1984, 1987; GRABER; RAKOSI; PETROVIC, 1997, 1999) que viveu em Bonn, Alemanha, de 1893 a 1973 (EIREW, 1981). Entretanto, a publicação do "Guia de la técnica del Bionator" (BALTERS, 1969) só ocorreu em 1969. Balters considerava que o equilíbrio entre a língua e os músculos circundantes influenciava a forma dos arcos dentários e a intercuspidação adequada, sendo a língua considerada o centro da atividade reflexa da cavidade bucal, e, portanto, o fator essencial ao desenvolvimento da dentição. Assim, a má oclusão deveria ser considerada como um distúrbio desse equilíbrio (GRABER; NEUMANN, 1984, 1987; GRABER; RAKOSI; PETROVIC, 1997, 1999). Segundo Balters, as más oclusões de Classe II ocorriam devido a um posicionamento posterior da língua. Desta forma, a língua deveria ser levada mais para anterior por meio da estimulação da parte posterior do dorso lingual. Além disso, a estimulação do crescimento mandibular, com o intuito de estabelecer a correção da má oclusão de Classe II, também traria reflexos positivos tanto para as vias respiratórias como para a deglutição. Para Balters, o Bionator levaria a uma normalização da função e a relações anatômicas harmoniosas (GRABER; NEUMANN, 1984, 1987).

A técnica de Balters priorizava o selamento labial para o tratamento de todos os tipos de más oclusões, condição considerada indispensável para o livre desenvolvimento do potencial de crescimento, que foi impedido pela função anormal (GRABER; NEUMANN, 1984, 1987).

De acordo com Balters, os pontos essenciais do tratamento eram: 1) obter o selamento dos lábios e trazer o dorso da língua em contato com o palato mole; 2) aumentar o espaço bucal e treinar sua função; 3) trazer os incisivos para um relacionamento topo-a-topo; 4) realizar alongamento da mandíbula, que, por sua vez, aumentaria o espaço bucal, tornando possível uma melhor posição da língua; 5) obter um melhor relacionamento das bases ósseas, da língua e dos dentes, como 
também dos tecidos moles circundantes (ASCHER, 1977; GRABER; NEUMANN, 1984, 1987). Posteriormente, Eirew (1981) enumerou os principais objetivos do tratamento com o Bionator da seguinte maneira: 1) eliminar a interposição do lábio e a relação anormal entre lábios e incisivos; 2) eliminar o trauma à mucosa palatina em decorrência da sobremordida profunda; 3) corrigir a retrusão mandibular e a má posição da língua; 4) obter um plano oclusal correto, quando necessário, pela ação impedidora da interposição lingual e da musculatura jugal. Esses objetivos são alcançados com a construção do aparelho com os incisivos em posição de topo ou o mais próximo possível desta relação.

Nos anos 80, a escola de Balters ainda era representada por um pequeno grupo de profissionais seguidores de sua filosofia, como Roberts que, em 1985, destacou que a má oclusão de Classe II resultava da posição posterior da língua, gerando deglutição atípica e respiração bucal. Atualmente, este mecanismo de ação alegado por Balters não encontra suporte, por nunca ter sido comprovado cientificamente (CRUZ, 2000).

\subsubsection{Tipos de aparelho}

Quanto à classificação, há três tipos de Bionator que se destinam à correção das diferentes anomalias esqueléticas e alterações funcionais: o Bionator base (FALTIN, C.O.; FALTIN JUNIOR, 1998; GRABER; NEUMANN, 1987), também conhecido como Bionator padrão (EIREW, 1981; GRABER; RAKOSI; PETROVIC, 1999); o Bionator invertido (FALTIN, C.O.; FALTIN JUNIOR, 1998; GRABER; NEUMANN, 1987), ou de inversão (GRABER; NEUMANN, 1987), ou reverso (GRABER; RAKOSI; PETROVIC, 1999), ou Classe III (GRABER; NEUMANN, 1987; GRABER; RAKOSI; PETROVIC, 1999); e o Bionator de proteção (GRABER; NEUMANN, 1987), ou fechado (FALTIN, C.O.; FALTIN JUNIOR, 1998; GRABER; NEUMANN, 1987), ou protetor (GRABER; RAKOSI; PETROVIC, 1999), ou de mordida aberta (GRABER; NEUMANN, 1987; GRABER; RAKOSI; PETROVIC, 1999). O Bionator base ou padrão é utilizado para o tratamento do retrognatismo mandibular (Classe II); o invertido, para corrigir o prognatismo mandibular (Classe III) e o fechado, para a correção das mordidas abertas com ou sem alterações esqueléticas (FALTIN, C.O.; FALTIN JUNIOR, 1998; GRABER; NEUMANN, 1987). 
Cabe ressaltar que as considerações a serem descritas daqui por diante a respeito do aparelho Bionator referir-se-ão ao tipo base ou padrão, por se tratar do aparelho a ser avaliado neste estudo.

\subsubsection{Indicações e contraindicações do Bionator padrão}

$\mathrm{Na}$ seleção dos casos a serem tratados com o Bionator, um correto diagnóstico diferencial torna-se essencial para um tratamento bem sucedido, e os casos passíveis de tratamento com esse aparelho devem apresentar retrusão mandibular e potencial de crescimento suficiente para permitir as alterações favoráveis (ALTUNA; NIEGEL, 1985; BISHARA, S.E.; ZIAJA, 1989; GRABER; NEUMANN, 1984, 1987; GRABER; RAKOSI; PETROVIC, 1997, 1999; JANSON, I.R.; NOACHTAR, 1998; MARTINS, L.P., 2001).

Desta maneira, as indicações do Bionator são similares às do Ativador (EIREW, 1981), e consistem em casos de Classe II moderada (EIREW, 1981; GRABER; RAKOSI; PETROVIC, 1997, 1999; JANSON, I.R.; NOACHTAR, 1998), com arcos bem alinhados ou pouco apinhamento (EIREW, 1981; GRABER; RAKOSI; PETROVIC, 1997, 1999; TSAMTSOURIS; VEDRENNE, 1983), padrão de crescimento favorável (HENRIQUES, 1997; JANSON, I.R.; NOACHTAR, 1998; MARTINS, L.P., 2001), altura facial inferior normal ou reduzida (ALTUNA; NIEGEL, 1985; EIREW, 1981; GRABER; RAKOSI; PETROVIC, 1997, 1999; TSAMTSOURIS; VEDRENNE, 1983) e presença de retrusão mandibular ou mandíbula subdesenvolvida (ALMEIDA, M.R., 2000a; ALTUNA; NIEGEL, 1985; BIGLIAZZI; KESSNER; FALTIN JUNIOR, 2000; BOLMGREN; MOSHIRI, 1986; FREITAS, B.V., 1996; GRABER; RAKOSI; PETROVIC, 1997, 1999; MAMANDRAS; ALLEN, 1990; MARTINS, L.P., 2001; OLIVEIRA, 1997; TSAMTSOURIS; VEDRENNE, 1983). Os casos de Classe II com sobressaliência acentuada, normalmente, apresentam maxilas estreitas (ALTUNA; NIEGEL, 1985). Nesses casos, ao se posicionar a mandíbula anteriormente com o Bionator, a largura das bases ósseas superior e inferior devem ser compatíveis. Se houver uma discrepância entre essa relação (a maxila cruzar com o avanço mandibular), o arco superior deve ser expandido inicialmente, antes da instalação do aparelho funcional (ALTUNA; NIEGEL, 1985; BIGLIAZZI; KESSNER; FALTIN JUNIOR, 2000). 
De acordo com Bishara e Ziaja, em 1989, os casos de Classe II, $1^{\text {a }}$ divisão ideais para a utilização de aparelhos funcionais seriam aqueles em que os pacientes se encontrassem na fase de crescimento, nos quais as extrações dentárias prejudicariam a estética facial, com os incisivos superiores protruídos e inferiores retruídos, sobremordida acentuada, padrão de crescimento horizontal ou equilibrado, e retrusão mandibular esquelética.

Em 2001, Ahn; Kim e Nahm pesquisaram as características cefalométricas iniciais dos pacientes que apresentaram sucesso na correção da má oclusão de Classe II, $1^{\text {a }}$ divisão, com a utilização do Bionator na fase da dentadura mista. Para isto, os autores dividiram os 40 jovens avaliados em dois grupos, um contendo pacientes que apresentaram bons resultados e no outro, os resultados não foram tão satisfatórios após o tratamento. $O$ padrão cefalométrico que melhor respondeu ao tratamento com o Bionator foi caracterizado por apresentar, inicialmente, um predomínio do vetor de crescimento horizontal, relação ântero-posterior entre as bases ósseas próxima do normal, incisivos inferiores verticalizados e retrusão do lábio inferior. Os autores concluíram que a indicação do Bionator e a eficácia do tratamento relacionam-se intimamente às características morfológicas faciais dos pacientes.

Graber; Rakosi e Petrovic (1997; 1999) também encontraram resultados semelhantes aos achados de Ahn; Kim e Nahm (2001) e relataram que o Bionator torna-se contraindicado se houver as seguintes condições: relacionamento de Classe II por prognatismo maxilar, padrão de crescimento predominantemente vertical e inclinação vestibular evidente dos incisivos inferiores.

\subsection{4 Época de tratamento com o Bionator}

Em relação à época ideal para se iniciar o tratamento ortopédico funcional com o Bionator, a maioria dos autores concorda que o paciente deve se encontrar na fase de crescimento craniofacial (ALMEIDA, M.R., 2000a; ALTUNA; NIEGEL, 1985; ARAÚJO, E.; SOUKI, 2003; BISHARA, S.E.; ZIAJA, 1989; HENRIQUES, 1991, 1997; JENA; DUGGAL; PARKASH, 2006; MARTINS, L.P., 2001; NASCIMENTO; CARVALHO, 2003; TULLOCH, 1997; TULLOCH; PROFFIT; PHILLIPS, 1997; WIESLANDER; LAGERSTROM, 1979), ou durante a dentadura mista (AHN; KIM; NAHM, 2001; BIGLIAZZI; KESSNER; FALTIN JUNIOR, 2000; CARELS; 
REYCHLER; VAN DER LINDEN, 1997; NASCIMENTO; CARVALHO, 2003; TSAMTSOURIS; VEDRENNE, 1983; TULLOCH, 1997; TULLOCH; PROFFIT; PHILLIPS, 1997). Diversos autores (JANSON, I., 1977, 1978; JANSON, M.; HASUND, 1981) investigaram os efeitos do tratamento com o Bionator em jovens nos estágios de crescimento pré-pubescente e pubescente (identificado por meio de radiografias carpais), e, observaram que as alterações dentoalveolares foram mais pronunciadas durante o estágio pré-pubescente, enquanto que as alterações esqueléticas foram mais evidentes no estágio pubescente. Faltin Jr. et al., em 2003, realizaram um estudo semelhante, onde dividiram a amostra experimental, composta por 23 pacientes, em dois grupos, de acordo com a idade esquelética avaliada pela maturidade das vértebras cervicais. Os resultados indicaram que o tratamento com o Bionator, seguido da terapia com aparelho fixo, é mais efetivo e estável quando instituído durante o pico de crescimento pubescente, em comparação a um tratamento mais precoce (no estágio pré-pubescente). Os autores concluíram que a época ideal para o início do tratamento ortopédico funcional é determinada pela visualização da concavidade das bordas inferiores da segunda e terceira vértebras cervicais. Jena; Duggal e Parkash (2006) descreveram que a época do tratamento ortopédico funcional (no caso, com os aparelhos Twin-block e Bionator) - no pico do surto de crescimento pubescente - desempenha um papel crucial, contribuindo para que haja uma predominância dos efeitos esqueléticos na correção da relação molar e da sobressaliência no tratamento da má oclusão de Classe II, 1a divisão. Os autores encontraram mais de $57 \%$ de contribuição esquelética na correção da Classe II com os aparelhos avaliados.

Em 1980, Pfeiffer sugeriu que o tratamento ortopédico funcional deve ser iniciado em jovens do gênero feminino por volta dos 10 anos de idade e finalizado próximo aos 13 anos, e nos pacientes do gênero masculino, deve-se iniciar aos 11 anos e 6 meses aproximadamente, e terminar aos 14 anos. Assim, inicia-se 0 tratamento antes do surto de crescimento e finaliza-se o mesmo um ano após esse surto.

Mamandras e Allen, em 1990, observaram que pacientes com mandíbulas pequenas se beneficiam mais do tratamento com o Bionator do que aqueles com mandíbulas de tamanho normal. Os pacientes que apresentam crescimento tardio podem experimentar mais desenvolvimento durante o tratamento em função do 
ambiente favorável de crescimento, propiciado pela terapia com o aparelho funcional.

\subsubsection{Efeitos do tratamento com o Bionator}

Os efeitos proporcionados pelo tratamento com o Bionator assemelham-se àqueles oriundos da terapia com o Ativador (CRUZ, 2000) e são predominantemente dentoalveolares (ALMEIDA, M.R., 2000b, 2004; ALMEIDA, M.R.; HENRIQUES; URSI, 2002; DRAGE; HUNT, 1990; JANSON, I.R.; NOACHTAR, 1998). Entretanto, alguns efeitos esqueléticos também podem ser observados.

Um dos primeiros estudos cefalométricos sobre a ação do Bionator foi publicado por Meach (1966). O autor avaliou e comparou as alterações do perfil esquelético em três grupos de jovens; dois que receberam o tratamento da Classe II, $1^{\text {a }}$ divisão por meio de forças extrabucais e aparelhos funcionais e um utilizado como controle. Observou que o aparelho funcional influenciou favoravelmente a posição do pogônio para anterior, promovendo uma diminuição do ângulo FMA e um aumento do ângulo facial. Deste modo, o autor verificou uma melhora no perfil esquelético, devido à normalização do processo de crescimento da Classe II, por meio da alteração dos componentes verticais e horizontais do complexo dentofacial, principalmente na região do côndilo mandibular.

Com a finalidade de averiguar e comparar os efeitos dentoesqueléticos do Bionator, quando utilizado nas fases pré-pubertária e pubertária, Janson (1977) avaliou cefalometricamente 207 jovens com Classe II, sendo 134 tratados e 73 não tratados. Obteve telerradiografias ao início e ao final do tratamento, que durou de 12 a 18 meses, após a obtenção de uma relação molar de Classe I e um trespasse vertical de $2 \mathrm{~mm}$. Utilizou radiografias carpais para analisar em qual fase (prépubertária e pubertária) o paciente se encontrava. Os resultados demonstraram que as alterações dentoalveolares foram mais pronunciadas durante o estágio prépubertário, enquanto que as alterações esqueléticas foram durante o estágio pubertário. Os efeitos dentoalveolares incluíram protrusão dos incisivos inferiores e retrusão dos superiores. Por outro lado, verificaram-se efeitos esqueléticos significantes durante o estágio pubertário, ocorrendo um aumento no comprimento mandibular. 
Janson e Hasund (1981) descreveram os resultados de um estudo com jovens pré-adolescentes e adolescentes tratados com o Bionator, do tipo adaptado por Ascher (1977), analisando o comportamento das mensurações esqueléticas e dentoalveolares. O grupo controle constava de 73 jovens, divididos em dois subgrupos de ortognatas e retrognatas, da mesma forma que o grupo experimental. Além disso, os jovens foram divididos em pré-pubertários e pubertários. Os resultados mostraram que não houve alterações esqueléticas significantes, enquanto que as alterações dentoalveolares predominaram no grupo experimental. Verificou-se uma diminuição do ângulo interincisivos, decorrente da inclinação para lingual dos incisivos superiores e inclinação para vestibular dos inferiores. As alterações esqueléticas foram mais significantes na fase pubertária para ambos os grupos tratados e para o grupo controle. $O$ aparelho promoveu maior efeito dentoalveolar durante o período pré-pubertário, possibilitando sua indicação precoce em casos com má oclusão severa.

Em 1982, Schulhof e Engel propuseram reavaliar cefalometricamente os resultados obtidos com os aparelhos funcionais e com o aparelho fixo Edgewise no tratamento da Classe II, $1^{\underline{a}}$ divisão. Examinaram 4 tipos de aparelhos funcionais: Bionator, Bimler, Ativador e Fränkel. Os resultados mostraram que o Bionator proporcionou um estímulo para o crescimento mandibular e aumento do eixo condilar e do corpo mandibular maior que o crescimento normal, enquanto que 0 ângulo goníaco e o eixo facial não alteraram significativamente. Observaram, ainda, uma inclinação significante dos incisivos superiores para lingual, uma vestibularização dos incisivos inferiores, e uma mesialização dos molares inferiores, diante da comparação com o grupo controle. Identificaram um crescimento mandibular maior nos grupos que utilizaram aparelhos funcionais. O padrão das alterações dentoesqueléticas mostrou-se independente do tipo de aparelho eleito, porém todos os aparelhos funcionais estudados promoveram um aumento no padrão facial no sentido vertical e a correção da má oclusão de Classe II, $1^{\text {ạ }}$ divisão.

A utilização do Bionator em jovens durante a fase de dentadura mista tardia propicia a correção da Classe II, por meio do estímulo do crescimento mandibular e pelas alterações dentárias e no perfil facial, além de proteger os dentes anterosuperiores de possíveis fraturas. Neste contexto, Tsamtsouris e Vedrenne (1983) descreveram o aparelho com suas diversas modificações e apresentaram os efeitos que o Bionator proporciona sobre as estruturas dentoalveolares, esqueléticas 
e tegumentares. Os autores destacaram algumas possibilidades do mecanismo de ação do aparelho, sendo: retração maxilar obtida por forças recíprocas diagonais entre os arcos, advindas por meio do reposicionamento anterior da mandíbula; expansão transversal da maxila; deslocamento distal dos dentes superiores; deslocamento mesial dos dentes inferiores e inclinação anterior dos incisivos inferiores; reposicionamento anterior mandibular; irrupção passiva dos dentes com aumento da altura dos processos alveolares que contribuem para abertura da mordida e aumento da altura facial inferior; rotação do plano oclusal e nivelamento da curva de Spee; e correção da relação molar de Classe II por meio da prevenção da irrupção dos molares superiores, propiciada pela cobertura de acrílico sobre estes dentes. A ausência de contato do acrílico com os molares inferiores permite 0 deslocamento mesial destes, corrigindo a relação molar.

Em 1991, Hashim estudou cefalometricamente 36 jovens (25 do gênero feminino e 11 do masculino), com média de idade de 12 anos e 2 meses, tratados com ativadores, por um período médio de 10 meses. Utilizou um método de sobreposição de telerradiografias para determinar o movimento dos molares, a modificação intermaxilar e a influência individualizada sobre as bases ósseas maxilar e mandibular. Os resultados apontaram que os principais efeitos encontrados foram dentoalveolares, não obstante tenha observado um pequeno efeito ortopédico na maxila. A mandíbula não experimentou um crescimento significante em relação ao crescimento mandibular esperado naturalmente.

Objetivando a determinação dos efeitos do Bionator sobre a morfologia dentoesquelético-facial, Lange et al. (1995) utilizaram uma amostra de 30 jovens com Classe II, $1^{\text {a }}$ divisão e idades variando entre 9 e 12 anos tratados por 18 meses com o Bionator. O aparelho utilizado foi uma variação daquele preconizado por Balters (BALTERS, 1969), uma vez que o acrílico recobria os incisivos inferiores. Confeccionou-se a mordida construtiva numa relação de topo-a-topo dos incisivos e abertura de 4 a $5 \mathrm{~mm}$ na região dos molares. Utilizou-se um grupo controle compatível com a idade e gênero da amostra tratada. Comparando-se os dois grupos, verificou-se no grupo tratado uma diminuição significante do ângulo SNA, porém analisando a medida Co-ENA não se verificou diferença entre os dois grupos. Concluíram que o Bionator produz um suave efeito de restrição do crescimento anterior da maxila. Por outro lado, notou-se um aumento significante no comprimento efetivo mandibular (Ar-Gn) e no ângulo SNB. Deste modo, houve uma diminuição do 
ângulo ANB de $1,97^{\circ}$. As alturas faciais anterior e posterior aumentaram significativamente, enquanto que o ângulo FMA não apresentou diferença entre os grupos. A convexidade facial diminuiu significantemente no grupo tratado. Não houve diferença significante entre os grupos, na avaliação do ângulo nasolabial. Os resultados aludiram um aumento no ângulo mentolabial de $17,4^{\circ}$. O lábio superior sofreu mínimo efeito com a terapia do Bionator.

Com o intuito de comparar os efeitos esqueléticos e dentários de 3 tipos de aparelhos ortopédicos funcionais, Cura, et al. (1996) utilizaram o aparelho ativador, o aparelho de Bass e o ativador combinado com a ancoragem extrabucal para 0 tratamento da Classe II, $1^{\underline{a}}$ divisão em 64 pacientes. Os autores evidenciaram uma melhora significante na relação maxilomandibular, observada pela redução do ângulo ANB, nos 3 grupos estudados. Contudo, verificaram que o aparelho de Bass proporcionou um maior controle da inclinação dos incisivos superiores e inferiores, reduzindo deste modo, a verticalização e a vestibularização, respectivamente. Da mesma forma, o aparelho ativador combinado com a ancoragem extrabucal, favoreceu o controle da inclinação para vestibular dos incisivos inferiores.

A interceptação precoce da má oclusão de Classe II tem sido objeto de intenso estudo por parte dos pesquisadores, pois a possibilidade de alteração do crescimento craniofacial durante a fase de dentadura mista torna-se extremamente importante. Defendendo a intervenção precoce nas más oclusões de Classe II, Tulloch et al. (1997) estudaram e compararam os efeitos do aparelho extrabucal e do Bionator de Balters sobre o padrão esquelético desta má oclusão. Para tanto, utilizaram um grupo controle de jovens apresentando má oclusão de Classe II que não utilizaram nenhum aparelho e foram observados por 15 meses. Os 3 grupos apresentaram idade inicial média de 9,4 anos, e não se verificou diferença significante nas medidas cefalométricas iniciais entre os grupos. Verificaram uma melhora significativa da Classe II nos grupos tratados, com redução significante do ângulo ANB. Entretanto, o mecanismo de redução do ANB não foi semelhante para os dois grupos tratados, sendo que os jovens que utilizaram o aparelho extrabucal apresentaram uma restrição do crescimento anterior da maxila. Por outro lado, notaram um maior aumento no comprimento mandibular nos jovens que utilizaram o Bionator. Concluíram que o tratamento precoce da Classe II, utilizando tanto o aparelho extrabucal como o aparelho funcional, proporciona $75 \%$ de chance de melhora no padrão maxilomandibular. 
Ainda no ano de 1997, Henriques et al. demonstraram por meio de um caso clínico, a aplicação da terapia com o Bionator para a correção das discrepâncias esqueléticas em uma primeira fase, e, posteriormente, a instituição de aparelhagem fixa para correção de problemas de origem dentária. Assim, com a combinação do tratamento ortopédico-ortodôntico conseguiu-se a normalização da relação das bases ósseas, promovendo uma melhora na estética facial. Analisando as alterações cefalométricas, verificaram um aumento no ângulo SNB e no comprimento mandibular efetivo (Co-Gn), o que propiciou uma melhora na relação anteroposterior das bases apicais (ANB). Não observaram restrição do crescimento maxilar (SNA e Co-A), mas a altura facial anteroinferior experimentou um aumento significante. Concluíram, ressaltando a importância da indicação do Bionator em jovens com padrão de crescimento equilibrado, bem como da aplicação desta terapia em pacientes colaboradores.

A controvérsia existente, na literatura, quanto à época de intervenção nas más oclusões de Classe II ainda continua sendo assunto de grande interesse, bem como a instituição de uma única fase tardia de tratamento ou duas fases, sendo uma precoce e outra tardia. Deste modo, Tulloch; Phillips e Proffit (1998) propuseram um estudo sobre os benefícios do tratamento precoce da Classe II, dividindo-o em duas fases. A amostra constou de 166 jovens na primeira fase do estudo e de 147 que continuaram na segunda fase. Utilizaram 3 grupos para as devidas comparações, sendo um controle de 61 jovens, 53 que foram tratados com o Bionator e 52 tratados com o aparelho extrabucal durante um período de 15 meses.

Verificaram uma melhora no relacionamento esquelético das bases ósseas em $5 \%$ dos jovens do grupo controle, enquanto que $15 \%$ destes mostraram uma piora marcante. Analisando os efeitos do tratamento com o Bionator e com 0 aparelho extrabucal, concluíram que ambas as estratégias reduziram a gravidade da discrepância esquelética das bases ósseas, evidenciada por uma redução significante do ângulo ANB. Entretanto, o mecanismo que propiciou esta melhora da Classe II foi diferente em ambos os grupos, em função de uma restrição do crescimento maxilar anterior, proporcionada pelo extrabucal e um maior aumento do comprimento mandibular com deslocamento anterior do mento evidenciado no grupo tratado com o Bionator. Finalizaram ressaltando que a severidade inicial da má oclusão de Classe II, bem como o tempo de tratamento não são fatores importantes nos resultados finais. A variabilidade no padrão de crescimento esquelético parece 
ser o grande contribuinte para as grandes variações nas diferentes respostas do tratamento.

Em 1998, Rudski-Janson e Noachtar asseveraram os diversos efeitos do tratamento com o Bionator, ressaltando que as principais alterações enquadram-se nas adaptações dentoalveolares. Mencionaram 3 fatores que devem ser levados em consideração para indicação do Bionator: o paciente deve apresentar um padrão de crescimento favorável, com rotação mandibular anterior e moderada discrepância esquelética; a morfologia individual e os objetivos do tratamento funcional devem ser obtidos por meio de guias individuais e não de valores médios propostos; e a indicação do Bionator nos casos de hábitos parafuncionais, respiração bucal e sobremordida. Concluindo, os autores ressaltam que os pré-requisitos para um tratamento eficiente utilizando o Bionator incluem: a seleção do paciente, baseada na morfologia individual e padrão de crescimento, bem como a construção precisa do aparelho.

Objetivando comparar os resultados de três investigações clínicas casuais, as

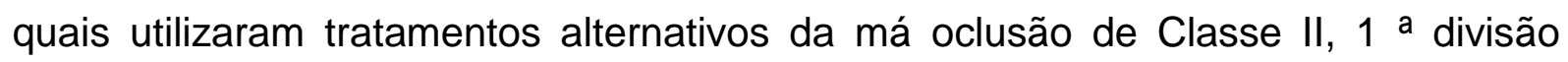
Ghafari; King e Tulloch (1998) reuniram os achados dos estudos das Universidades da Carolina do Norte, Flórida e da Universidade da Pensilvânia. Para tanto, foram utilizados aparelhos funcionais (Bionator e Fränkel) e aparelhos extrabucais. Os resultados da Universidade da Carolina do Norte (UNC) demonstraram que os aparelhos Bionator e extrabucal promoveram uma redução significante da discrepância esquelética em comparação com o grupo controle. $O$ aparelho extrabucal mostrou-se mais efetivo sobre o complexo maxilar, promovendo um maior efeito restritivo do crescimento da maxila (SNA). O Bionator denotou efeito semelhante ao grupo controle, ou seja, não atuou restringindo o crescimento maxilar. Por outro lado, o Bionator promoveu um maior deslocamento anterior da mandíbula (SNB) e um maior aumento no comprimento mandibular, em comparação aos grupos controle e extrabucal. Os resultados encontrados pela Universidade da Flórida denotaram que tanto o aparelho extrabucal como o Bionator atuaram de maneira semelhante sobre a maxila em comparação ao grupo controle; porém o extrabucal promoveu maior distalização dos molares superiores. Analisando a posição mandibular, tanto o extrabucal quanto o Bionator responderam de forma semelhante deslocando-a anteriormente com maior intensidade que o grupo controle. Os resultados divulgados pela Universidade da Pensilvânia demonstraram que o 
extrabucal propiciou uma maior restrição do crescimento anterior da maxila (SNA), em comparação com o aparelho de Fränkel. Os molares foram distalizados com maior intensidade no grupo que utilizou o extrabucal. $O$ aparelho de Fränkel possibilitou um maior deslocamento anterior da mandíbula. Entretanto, o comprimento mandibular encontrado, utilizando ambos os aparelhos, foi semelhante.

Ainda no ano de 1998, Illing; Morris e Lee publicaram dois artigos avaliando os efeitos de aparelhos ortopédicos (Bionator, Bass e Twin Block) sobre as estruturas dentoesqueléticas e tegumentares. A amostra compreendeu 47 pacientes tratados com um dos três aparelhos referidos e foi comparada a um grupo controle não tratado. $O$ Bionator e $O$ Twin Block produziram um aumento significante no comprimento mandibular e uma diminuição na inclinação dos incisivos superiores. A altura facial inferior aumentou em todos os grupos tratados. Quanto às alterações do tecido mole, observaram um aumento no comprimento e protrusão do lábio inferior e aumento na altura facial total e inferior em todos os grupos tratados com os aparelhos referenciados. Os autores asseguraram que o Bionator e o Twin Block apresentaram maior efetividade, produzindo maiores alterações sagitais e verticais.

Com o propósito de comparar as alterações dentoalveolares, esqueléticas e faciais produzidas pelos aparelhos Fränkel e Bionator na correção da Classe II, $1 \stackrel{a}{\underline{a}}$ divisão, Almeida; Henriques e Ursi (2002) conduziram uma pesquisa com 66 pacientes. A amostra foi dividida em três grupos de 22, sendo 11 do gênero masculino e 11 do feminino. Os jovens do grupo 1 foram mantidos como controle e apresentaram uma idade inicial média de oito anos e sete meses. O grupo 2 foi submetido ao tratamento utilizando o aparelho de Fränkel, com idade inicial média de nove anos. O grupo 3 foi tratado com o Bionator de Balters, e apresentava idade inicial média de dez anos e oito meses. Para cada jovem corresponderam duas telerradiografias, obtidas no início e no final do período de acompanhamento. Os resultados demonstraram que os aparelhos referidos não promoveram alterações no desenvolvimento maxilar. No entanto, produziram um aumento na protrusão mandibular e nos comprimentos efetivo e do corpo da mandíbula, com valores maiores para o grupo 3. A relação maxilomandibular melhorou significantemente nos grupos tratados em comparação ao grupo controle. A análise do padrão de crescimento craniofacial não revelou alteração significante entre os grupos. A altura facial anteroinferior não denotou alteração significante, porém no grupo 3 , a altura facial posterior aumentou significantemente. As alterações dentoalveolares 
demonstraram que os incisivos superiores e inferiores inclinaram-se, respectivamente, para lingual e para vestibular nos grupos tratados. Os molares inferiores apresentaram um maior desenvolvimento vertical nos grupos 2 e 3 . Os aparelhos de Fränkel e Bionator promoveram uma retrusão do lábio superior e uma protrusão do lábio inferior.

Em 2002, Chen; Will e Niederman realizaram uma pesquisa com o intuito de verificar se os aparelhos ortopédicos (Bionator, Bass, Fränkel, Twin Block) para 0 tratamento da Classe II realmente estimulam o crescimento mandibular. Os autores avaliaram 17 artigos anteriormente publicados e selecionaram 6 pesquisas que preencheram os requisitos desejados. Foram analisadas 12 medidas cefalométricas, sendo 10 lineares e 2 angulares. Os resultados demonstraram que apenas as medidas Ar-Pog e Ar-Gn apresentaram diferença estatisticamente significante comparando os grupos tratados e controle. Os autores concluíram que se deve reavaliar o uso destes aparelhos com a finalidade de estimular o crescimento da mandíbula.

Em 2004, Almeida et al. avaliaram cefalometricamente as alterações esqueléticas e dentoalveolares propiciadas pelo Bionator no tratamento da má oclusão de Classe II, $1^{\text {a }}$ divisão. Utilizaram uma amostra com 44 pacientes, sendo 22 tratados e 22 jovens com má oclusão semelhante que não receberam tratamento ortodôntico. Os resultados mostraram que o Bionator não promoveu alterações no desenvolvimento maxilar. No entanto, produziu um aumento na protrusão mandibular e nos comprimentos efetivo e do corpo da mandíbula. A análise do padrão de crescimento craniofacial não revelou alteração significante entre os grupos, porém, no grupo tratado a altura facial posterior (S-Go) aumentou significantemente. Os incisivos superiores inclinaram para lingual e os inferiores para vestibular com o tratamento instituído. Os autores concluíram que a correção da má oclusão de Classe II, 1 a divisão com o Bionator, ocorre pela combinação de efeitos esqueléticos na mandíbula e também, em grande parte, por alterações dentoalveolares significantes.

Com o propósito de verificar se os aparelhos ortopédicos funcionais aumentam o crescimento mandibular, Cozza et al., em 2006, realizaram uma revisão sistemática da literatura, buscando as respostas de alguns questionamentos: "a mandíbula cresce mais em indivíduos Classe II tratados com aparelhos funcionais do que em indivíduos Classe II não tratados?"; "os efeitos dos aparelhos funcionais no 
comprimento mandibular são clinicamente significantes?" e "quais aparelhos funcionais são mais eficientes?". Para isto, os autores qualificaram e selecionaram 22 artigos dentre os 704 encontrados na literatura. Os aparelhos avaliados foram: Ativador, Bass, Bionator, FR-2 de Fränkel, MARA, Twin-block e Herbst. Os autores concluíram que: 2/3 das amostras nos 22 estudos considerados apresentaram aumento clinicamente significante no comprimento total da mandíbula, como um resultado especialmente do tratamento ativo com aparelhos funcionais; à curto prazo, a quantidade de crescimento mandibular parece ser significantemente maior quando o tratamento funcional é realizado no pico de crescimento pubescente, e o aparelho de Herbst mostrou o maior coeficiente de eficiência $(0,28 \mathrm{~mm}$ por mês) seguido pelo Twin-block (0,23 mm por mês).

Alguns trabalhos, ainda (BIRKELAND et al., 1997; BISHARA, S.E.; ZIAJA, 1989; VARGERVIK; HARVOLD, 1985), apontam que há uma remodelação da fossa articular, bem como do côndilo (ARAÚJO, A.M.; BUSCHANG; MELO, 2004; HIRZEL; GREWE, 1974; MELO, 2006; RABIE; SHE; HAGG, 2003a), em decorrência da terapia ortopédica funcional. Melo et al. (2006) relataram uma alteração, no crescimento condilar, após a utilização do Bionator, nos três casos estudados, caracterizada por uma direção mais posterior, fato que, de acordo com os autores, contribuiu para a correção da relação anteroposterior entre a maxila e a mandíbula.

Rabie; She e Hägg, em 2003, observaram, por meio de um estudo em ratas, que os aparelhos ortopédicos de avanço mandibular aceleram e aumentam o crescimento condilar. Segundo os autores, isto ocorre devido a uma maior diferenciação de células mesenquimais em condrócitos, induzindo a uma maior quantidade de matriz cartilaginosa. Posteriormente, em 2004, Araújo; Buschang e Melo objetivaram descrever as alterações do crescimento condilar e da remodelação mandibular ocorridas com a terapia por meio do Bionator. Os resultados revelaram alterações significantes na direção (mais posterior), mas não na quantidade total de crescimento condilar. O Bionator produziu um deslocamento posterior das variáveis avaliadas nas regiões condilar e goníaca, maior que o esperado. A sobreposição na base do crânio revelou um deslocamento mandibular anterior maior do que o esperado, e uma rotação mandibular para anterior discreta ou praticamente inexistente. Assim, o Bionator produz alterações na direção do crescimento condilar e no deslocamento mandibular. 
As alterações tegumentares advindas da terapia com o Bionator resumem-se em retrusão do lábio superior (ALMEIDA-PEDRIN, 2003; ALMEIDA, M.R., 2000a, 2000b; ALMEIDA, M.R.D., 2001) e protrusão do lábio inferior (ALMEIDA-PEDRIN, 2003; ALMEIDA, M.R., 2000a, 2000b; ALMEIDA, M.R.D., 2001; HENRIQUES, 2001; ILLING; MORRIS; LEE, 1998; MALTAGLIATI, 2004). Entretanto, alguns autores (BRANGELI, 2000; HENRIQUES, 2001; LANGE et al., 1995; MALTAGLIATI, 2004) demonstraram que o lábio superior não sofreu efeito significante com o uso do Bionator. Outros também (FREITAS, B.V., 1996; FREITAS, B.V.; VIGORITO, 1999) relataram que a posição do lábio inferior se manteve inalterada. Alguns autores (ALMEIDA-PEDRIN, 2003; ALMEIDA, M.R., 2000a, 2000b; ALMEIDA, M.R.D., 2001) consideram ainda que esse aparelho não induz alterações substanciais no ângulo nasolabial, enquanto outros pesquisadores (LO; HUNTER, 1982; OLIVEIRA, 1997) relatam um aumento deste ângulo em decorrência da lingualização dos incisivos superiores. Lange et al. (1995), por sua vez, observaram um aumento no ângulo mentolabial (ou diminuição da sua profundidade) em decorrência do tratamento funcional com o Bionator, também verificado por Brangeli, em 2000 e 2004; e por Proffit; Tulloch (2002) que relataram uma projeção do queixo após o tratamento com o Bionator.

Em 2006, Flores-Mir e Major realizaram uma revisão sistemática da literatura, objetivando elucidar as alterações tegumentares decorrentes do tratamento da má oclusão de Classe II, 1a divisão, por meio dos aparelhos Ativador e Bionator; os autores verificaram que há grandes controvérsias a esse respeito, e ponderaram que alterações tegumentares relatadas como sendo estatisticamente significantes apresentam significância clínica questionável. Assim, os autores ressaltaram a necessidade do desenvolvimento de estudos clínicos duplo-cegos, prospectivos, randomizados, a fim de confirmarem os resultados encontrados.

De acordo com Bishara e Ziaja, em 1989, a combinação dos efeitos dentoalveolares (60\% a 70\%) e esqueléticos (30\% a 40\%) permite a correção efetiva da má oclusão de Classe II por meio dos aparelhos ortopédicos funcionais removíveis (os autores avaliaram o Ativador e o Regulador Funcional). 


\subsubsection{Tempo de tratamento com o Bionator}

Bishara e Ziaja (1989) sugerem que os aparelhos ortopédicos devem ser utilizados por um período de tempo prolongado, geralmente de um ano e meio a dois anos, para assegurar uma completa adaptação condilar, após a remodelação da fossa articular.

$\mathrm{Na}$ literatura consultada, o tempo médio de tratamento com o Bionator variou de 10,8 meses (OLIVEIRA, 1997) à 24 meses (MELO, 2006). A grande maioria dos autores relata um tempo médio de uso desse aparelho entre um ano (12 meses) e um ano e meio (18 meses) (ALMEIDA-PEDRIN, 2003; ALMEIDA, M.R., 2000a, 2000b; ALMEIDA, M.R.D., 2001; BOLMGREN; MOSHIRI, 1986; BRANGELI, 2000; GRABER; NEUMANN, 1984, 1987; HENRIQUES, 1991, 1997, 2001; JANSON, I., 1977, 1978; LANGE et al., 1995; MARTINS, L.P., 2001; NASCIMENTO; CARVALHO, 2003). De acordo com Jena; Duggal e Parkash (2006), o tempo de tratamento varia consideravelmente, dependendo do nível de cooperação do paciente e da velocidade de esfoliação dos dentes decíduos. Já, para a segunda fase do tratamento, realizada com aparelhos fixos (às vezes associados com 0 aparelho extrabucal) (NASCIMENTO; CARVALHO, 2003), os autores relatam um tempo variando de 9 meses (HENRIQUES, 1997) à 18 meses (NASCIMENTO; CARVALHO, 2003).

\subsubsection{Segunda fase do tratamento - aparelho ortodôntico fixo}

Embora existam casos nos quais o tratamento apenas com o Bionator é possível, na maioria das vezes, torna-se necessária uma combinação de medidas terapêuticas para produzir melhores resultados (GRABER; RAKOSI; PETROVIC, 1997, 1999). Movimentos dentários especiais (por exemplo: rotações, torque, movimentos de corpo para fechamento de espaço, distalizações para abrir espaço) não podem ser realizados pelo Bionator (GRABER; RAKOSI; PETROVIC, 1997, 1999). Nestes casos, os aparelhos fixos promovem um melhor controle individual dos dentes (GRABER; RAKOSI; PETROVIC, 1997, 1999), permitindo o alinhamento, nivelamento e acabamento final dos arcos dentários (NASCIMENTO; CARVALHO, 2003). A associação das terapias ortopédica e ortodôntica objetiva a correção dos problemas esqueléticos e dentários, modificando 0 relacionamento 
maxilomandibular, bem como, movimentando os dentes para suas posições ideais em relação às bases ósseas, a fim de se obter oclusões estática e funcional ideais (HENRIQUES, 1997).

A sequência mais racional para o tratamento das más oclusões, sob o ponto de vista de Pfeiffer e Grobety (1975) consiste, primeiramente, na remodelação óssea, seguida da obtenção da harmonia muscular e, finalmente, das movimentações dentárias. O tratamento ortopédico prévio favorece uma harmonia entre as bases ósseas, alterando a forma e a posição dos maxilares para posteriormente atingir uma oclusão satisfatória com a ortodontia corretiva. Com o aparelho fixo corrigem-se as angulações, as inclinações e as rotações dentárias (PFEIFFER; GROBETY, 1975).

Após comprovar a efetividade da associação ortopédico-ortodôntica, Bass (1983a; 1983b) concluiu que a técnica ortopédica permite a correção funcional dos tecidos moles e a coordenação do desenvolvimento facial e dentário quando utilizada em associação com a ortodontia corretiva, permitindo consideráveis vantagens no tratamento da má oclusão de Classe II esquelética.

De acordo com Henriques et al. (1991), a associação dos tratamentos ortodônticos e ortopédicos constitui-se num dos principais procedimentos clínicos para a correção das más oclusões de Classe II, 1aㅡ divisão com discrepância anteroposterior entre as bases apicais. Assim, a primeira fase do tratamento visa ao estabelecimento de uma relação normal entre as bases ósseas, eliminando desta forma, as possíveis interferências dos tecidos moles nas estruturas dentárias. Somente após este procedimento, inicia-se a movimentação ortodôntica para, enfim, obter uma oclusão satisfatória. A finalidade da utilização dos aparelhos fixos, posteriormente à terapia ortopédica funcional, é movimentar os dentes para suas posições ideais em relação às respectivas bases e obter a oclusão ideal, tanto anatômica como funcional.

Os autores consideram que a combinação do tratamento ortopédicoortodôntico, para os casos de Classe II, 1a divisão, é de suma importância para a obtenção de uma melhor estética e estabilidade, e concluem que este protocolo de tratamento proporciona as seguintes vantagens, também observadas por Bass em 1983: coordenação do crescimento maxilomandibular; adaptação precoce da musculatura bucofacial; a motivação do paciente e familiares se eleva em decorrência da rápida mudança da posição mandibular; redução significante da 
necessidade de extrações; proporciona movimentações dentárias menores durante a fase com aparelho fixo; menor tempo de utilização dos aparelhos fixos e maior estabilidade, com menor risco de recidiva.

Araújo et al. (2004), ao discorrerem a respeito do tratamento da Classe II em duas fases, relataram que a ortopedia facial permite uma correção inicial no sentido anteroposterior, vertical e transversal, diminuindo ou até mesmo corrigindo a discrepância esquelética existente. A utilização dos aparelhos ortopédicos irá facilitar a segunda fase do tratamento, que consiste na fase corretiva com aparelho fixo.

Nascimento e Carvalho (2003) ressaltaram a conveniência do tratamento por meio da junção dos recursos disponíveis da ortodontia e ortopedia facial em benefício do paciente. Com um correto diagnóstico e planejamento, as alterações esqueléticas e dentárias conseguidas com a ortodontia e a ortopedia facial não demandam tempo exorbitante de tratamento.

\subsubsection{Contenção e estabilidade do tratamento com o Bionator}

O estudo da recidiva da sobremordida e da sobressaliência após o tratamento da Classe II, 1ํㅡㄹ divisão com o Ativador realizado por Pancherz, em 1977, mostrou que essa recidiva poderia ser uma recuperação fisiológica da condição original do paciente e que algumas explicações parciais para este problema seriam métodos impróprios de tratamento, contenções insuficientes, alterações desfavoráveis de crescimento após o tratamento e persistência de hábitos de interposição lingual. Entretanto, a interceptação no desenvolvimento maxilomandibular desfavorável com a consequente normalização das condições oclusal e muscular podem influenciar favoravelmente o padrão de crescimento, tanto da maxila quanto da mandíbula no período pós-tratamento, de acordo com Wieslander e Lagerstrom em 1979.

Para minimizar ou evitar que ocorra essa recidiva, torna-se de suma importância a utilização de contenções após o tratamento ortopédico funcional. Assim, Graber e Neumann $(1984,1987)$ recomendam que, após o tratamento com o Bionator, o mesmo aparelho seja utilizado somente durante a noite como contenção. O período de contenção pode variar de 6 meses a 1 ano, ou mais. O aparelho passa a ser utilizado, gradualmente, por menos tempo à noite e menos vezes. $O$ paciente deverá ser instruído a usar novamente o aparelho com mais frequência se, depois 
de certo intervalo, houver tensão muscular ao ser inserido o aparelho (GRABER; NEUMANN, 1984, 1987).

Outro protocolo de contenção após a terapia com o Bionator foi utilizado por Henriques et al. em 1991 e 1997. Refere-se à utilização do aparelho extrabucal tipo Kloehn, durante 12 horas por dia, juntamente com o aparelho fixo (durante a $2^{\text {a }}$ fase do tratamento combinado ortopédico-ortodôntico), com o objetivo de conter 0 deslocamento anterior da maxila e aprimorar a relação molar de Classe I. Após a conclusão da $2^{\mathrm{a}}$ fase do tratamento, instalou-se uma placa de Hawley superior e um arco lingual colado de canino a canino no arco inferior $(3 \times 3)$.

Pesquisando os fatores que podem levar à recidiva da correção da sobressaliência por meio de aparelhos funcionais, Drage e Hunt (1990) compararam cefalometricamente as alterações do tratamento e pós-tratamento entre jovens tratados com Ativador ou Bionator e jovens não tratados (grupo controle). Os autores concluíram que a redução da sobressaliência ocorreu, principalmente, em decorrência de alterações dentoalveolares. As alterações das inclinações dos incisivos superiores para vestibular e em menor grau dos incisivos inferiores para lingual contribuíram para a recidiva da sobressaliência. Não houve evidências de que um padrão de crescimento vertical pudesse influenciar a recidiva. Observou-se que os jovens que sofreram uma grande redução da sobressaliência durante o tratamento apresentaram maior recidiva. Embora a inclinação vestibular dos incisivos superiores após o tratamento tenha se associado com a quantidade de inclinação para lingual desses dentes durante o tratamento, não se verificou nenhuma relação entre as alterações do tratamento e pós-tratamento na inclinação dos incisivos inferiores.

Em 1991, DeVincenzo analisou as alterações no comprimento mandibular antes, após a correção da má oclusão de Classe II, por meio de um aparelho ortopédico funcional, seguido do tratamento com aparelho ortodôntico fixo e após um período de contenção e observação. Os resultados revelaram um aumento inicial marcante no comprimento mandibular durante a fase ortopédica. No entanto, durante a fase ortodôntica a velocidade de crescimento mandibular diminuiu significantemente em relação aos pacientes do grupo controle (não tratados). A quantidade de crescimento no comprimento mandibular, desde a instalação do aparelho até o período de observação final, permaneceu similar entre os grupos tratado e controle. O autor concluiu que o comprimento mandibular aumenta de 
modo significante até 2 anos após o final do tratamento; porém, não ocorrem diferenças significantes em relação a jovens não tratados após o quarto ano.

Keeling et al. (1998) propuseram-se a avaliar se as alterações proporcionadas pela terapia ortopédica funcional se perpetuam com o crescimento normal posterior, se ocorre recidiva, a natureza da mesma (dentária ou esquelética), e se a contenção entre as fases de tratamento (ortopédica e ortodôntica) é necessária. Os autores avaliaram 70 jovens com má oclusão de Classe II tratados com o Bionator, nas fases pré-tratamento, pós-tratamento, pós-contenção e controle de 6 meses após a remoção da contenção. Concluíram que o crescimento facial é alterado pelo tratamento, e que o tempo de contenção de 6 meses não influenciou as alterações obtidas. A recidiva observada no período de 6 meses após a remoção da contenção foi de origem dentária. Assim, ressaltaram a importância do Ortodontista estar ciente de que a contenção é necessária para prevenir recidivas dentárias, mas não esqueléticas.

Enfim, observa-se que a literatura é vasta em relação aos efeitos imediatos da terapia com o Bionator, revelando resultados animadores. No entanto, verifica-se a escassez de estudos com relação à estabilidade em longo prazo desses efeitos. Como a estabilidade é essencial para se determinar o sucesso do tratamento, este trabalho visou verificar o comportamento desses efeitos em longo prazo, considerando o crescimento e desenvolvimento craniofacial e os efeitos provocados durante o tratamento. 

3 Proposição 



\section{PROPOSIÇÃO}

Este trabalho teve o propósito de avaliar cefalometricamente e, por meio de modelos de estudo, a estabilidade das alterações dentárias, esqueléticas e tegumentares de 23 jovens com má oclusão de Classe II, 1a divisão, tratados, na clínica de pós-graduação da disciplina de Ortodontia da Faculdade de Odontologia de Bauru, por meio do aparelho Bionator de Balters, associado ao aparelho ortodôntico fixo, após um período médio de 10 anos.

As áreas verificadas com relação às alterações dentárias, esqueléticas e tegumentares foram:

3.1 Componente maxilar;

3.2 Componente mandibular;

3.3 Relação maxilomandibular;

3.4 Padrão facial;

3.5 Componente dentoalveolar superior;

3.6 Componente dentoalveolar inferior;

3.7 Relações dentárias;

3.8 Tecidos moles e,

3.9 Índice oclusal. 



\section{Material e métodos}





\section{MATERIAL E MÉTODOS}

\subsection{Material}

Utilizou-se uma amostra prospectiva de um grupo de jovens, em média 10 anos após a finalização do tratamento com o aparelho Bionator de Balters, seguido de aparelho fixo, tratados no curso de pós-graduação, strictu sensu, a qual se encontra em controle no arquivo da Disciplina de Ortodontia da Faculdade de Odontologia de Bauru /USP.

Fizeram parte dessa amostragem 23 pacientes, com idade inicial média de 11,74 (TABELA 1), de ambos os gêneros, sendo 13 do gênero feminino e 10 do masculino, com um total de 69 telerradiografias e 69 modelos selecionados, obtidos nas fases: inicial (T1), final (T2) e longo tempo pós-tratamento (T3).

TABELA 1 - Médias, desvios-padrão, valor mínimo e máximo das idades inicial (T1), final (T2), longo tempo pós-tratamento (T3), período de tratamento (T1-T2) e período de longo tempo pós-tratamento (T2-T3).

\begin{tabular}{l|c|c|c|c}
\hline \multicolumn{1}{c|}{ Fase/Período } & Média (o) & Mínima (o) & Máxima (o) & D.P. \\
\hline Idade em T1 & 11,74 & 9,92 & 14,42 & 1,30 \\
\hline Idade em T2 & 15,38 & 13,00 & 19,50 & 1,69 \\
\hline Idade em T3 & 24,99 & 18,83 & 32,92 & 3,37 \\
\hline Tempo de T1-T2 & 3,55 & 1,08 & 7,33 & 2,14 \\
\hline Tempo de T2-T3 & 9,91 & 5,00 & 17,42 & 3,66 \\
\hline
\end{tabular}

Considerando-se o tipo de má oclusão, todos os pacientes apresentavam, no início do tratamento, Classe $\mathrm{II}, 1^{\text {a }}$ divisão. Em relação à severidade da discrepância anteroposterior, 14 pacientes apresentavam Classe II completa, 7 3/4 de Classe II e 2 $1 / 2$ Classe II de Andrews (MOYERS et al., 1980). A relação molar foi corrigida por meio do uso do aparelho Bionator de Balters seguindo-se de instalação do aparelho ortodôntico fixo.

Como o objetivo da pesquisa foi o de avaliar a estabilidade desse tipo de tratamento, os jovens selecionados tiveram seus tratamentos finalizados há, no mínimo 5 anos, e no máximo há 17,42 anos, resultando em um período médio de longo tempo pós-tratamento de 10 anos, com a idade média neste período de 24,99 anos (D.P $=3,51$, variando de 18,83 a 32,92 ). 
Os jovens selecionados deveriam apresentar as seguintes características:

- inicialmente, má oclusão de Classe II, $1^{\text {a }}$ divisão com uma relação molar de no mínimo 1/2 Classe II;

- procedentes dos cursos de Pós-graduação em Ortodontia da Faculdade de Odontologia de Bauru, Universidade de São Paulo;

- finalizaram o tratamento completo (Aparelho Bionator de Balters seguido de mecânica com fixo) há, no mínimo, 5 anos;

- ao final do tratamento, deveriam apresentar uma relação molar de Classe I e trespasse horizontal normal.

\subsection{Métodos}

\subsubsection{Protocolo de tratamento}

\subsubsection{Ortopedia funcional}

O aparelho Bionator utilizado apresenta algumas modificações considerandose o aparelho original proposto por Balters (BALTERS, 1969). Essas modificações foram propostas por Ascher em 1977 (FIGURA 1). O Bionator apresenta, na sua constituição, quatro elementos básicos: uma base de acrílico, alças palatina e vestibular e dobras do bucinador (FIGURA 2), sendo que, dependendo do tipo de aparelho, pode vir a apresentar características específicas de acordo com as diferentes finalidades. Algumas propriedades foram adicionadas ao aparelho original proposto por Balters (BALTERS, 1969). A parte anteroinferior de acrílico recobre os incisivos inferiores, limitando a extrusão e protrusão dos mesmos (JANSON, I.R.; NOACHTAR, 1998). A alça vestibular, originalmente para guiar ou facilitar o selamento labial, pode tocar os incisivos superiores funcionando assim, como elemento ativo durante o tratamento (MARTINS, J.C.R., 1997). Além disso, a extensão de acrílico no arco inferior projeta-se mais que 2 a $3 \mathrm{~mm}$, quando comparado ao original, a fim de se obter um melhor efeito dentário (MARTINS, J.C.R., 1997).

Visando à padronização do avanço mandibular no sentido anteroposterior, executou-se a mordida construtiva utilizando um rolete de lâmina de cera $\mathrm{n}^{0} \mathbf{7}$, 
objetivando a orientação nos planos horizontal, vertical e transversal (JANSON, I.R.; NOACHTAR, 1998). No sentido horizontal, a mandíbula foi avançada $5 \mathrm{~mm}$ e no vertical abriu-se a mordida cerca de $5 \mathrm{~mm}$. Para os casos que apresentavam um trespasse horizontal maior que $7 \mathrm{~mm}$, realizava-se um avanço mandibular gradual, ou seja, a cada 3 meses respeitando o limite de 2 a $3 \mathrm{~mm}$ a cada avanço. No sentido transversal, manteve-se a coincidência das linhas medianas esqueléticas superior e inferior. Nos casos de desvio da linha média dentária, manteve-se o desvio durante a confecção da mordida construtiva.
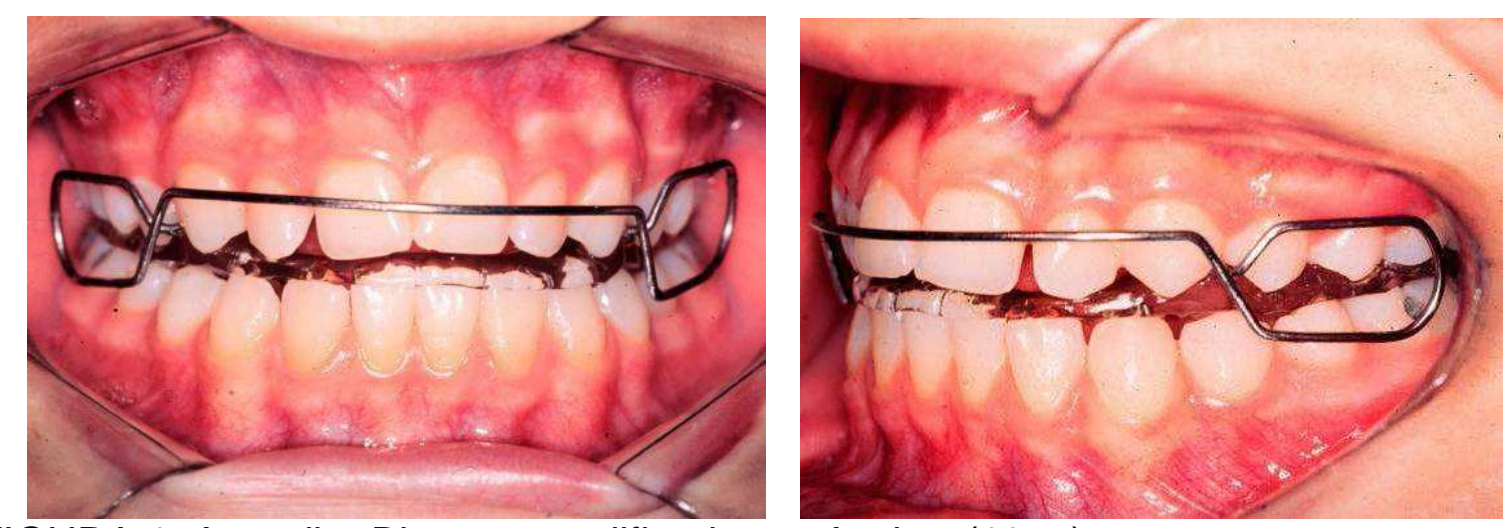

FIGURA 1: Aparelho Bionator modificado por Ascher (1977)
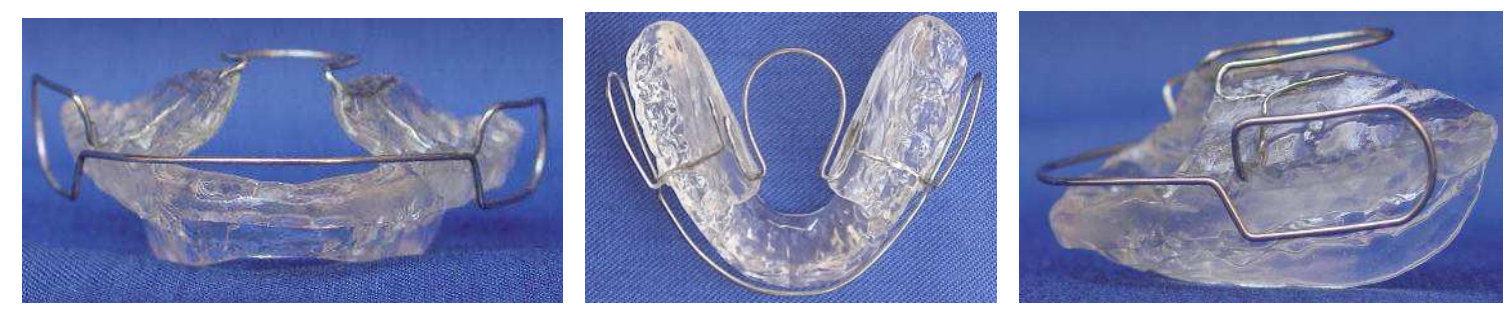

FIGURA 2: Aparelho Bionator - componentes

\subsubsection{Ortodontia corretiva}

Após a obtenção de uma relação anteroposterior normal, por meio do aparelho Bionator, os pacientes foram submetidos ao tratamento ortodôntico corretivo (FIGURA 3) para o alinhamento e nivelamento dos dentes, visando a uma boa oclusão estática e funcional. Alguns pacientes usaram braquetes "edgewise" enquanto que, em outros, seguiu-se os princípios da mecânica do arco reto (préajustado), de acordo com a prescrição Roth. Observou-se que a grande maioria utilizou o aparelho extrabucal (KHG), como contenção ativa, por aproximadamente 14h/dia, durante toda a fase de ortodontia corretiva. Além disso, ao final do tratamento, frequentemente, lançava-se mão do uso de elásticos de Classe II. Essa 
fase de mecânica corretiva durou, em média, 1,6 anos. Após a finalização do tratamento, utilizou-se, como contenção, a placa de Hawley modificada no arco superior e $03 \times 3$ inferior.

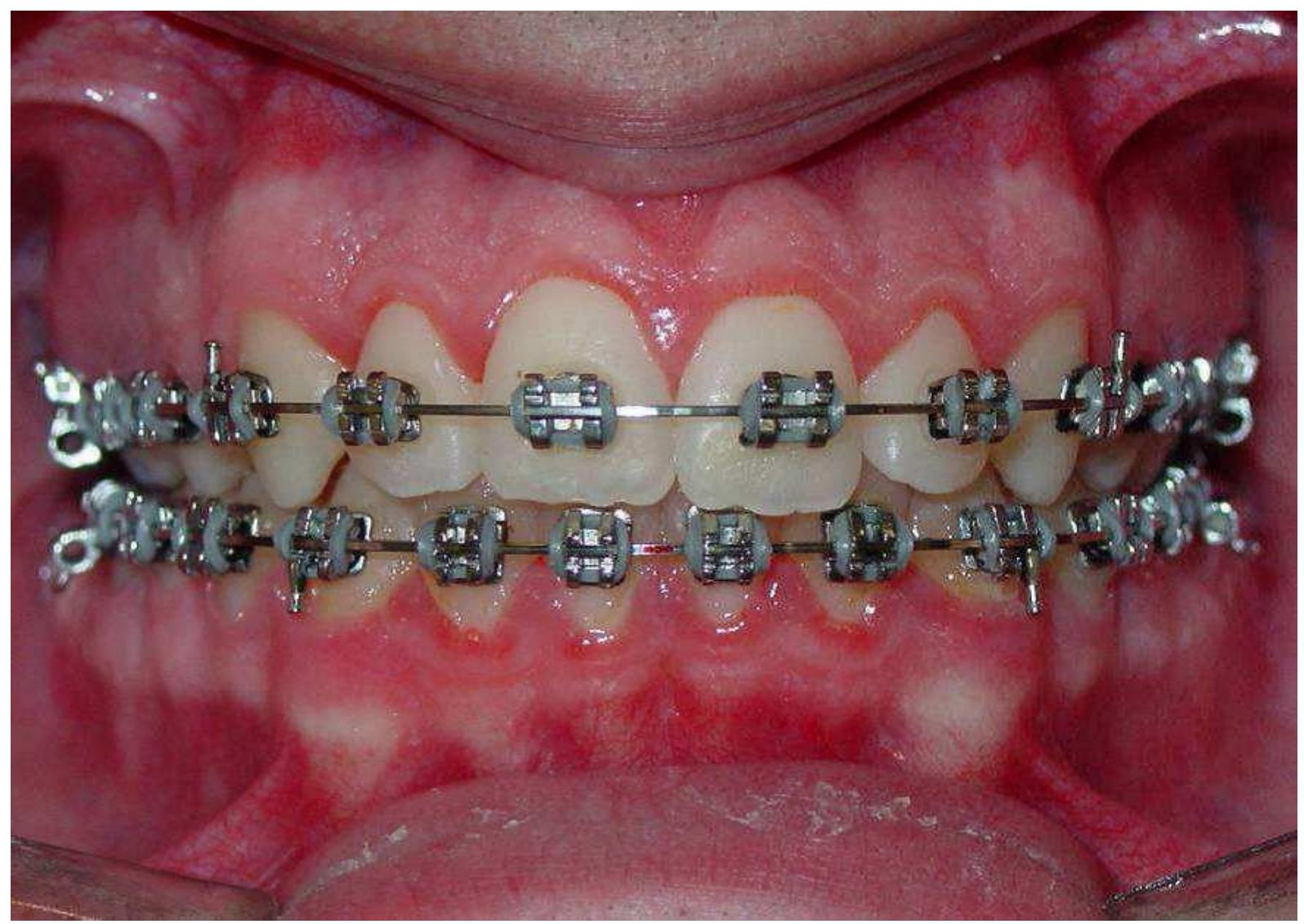

FIGURA 3: Aparelho ortodôntico fixo

\subsection{Método Radiográfico}

Para a realização deste estudo, foram utilizadas três telerradiografias em norma lateral de cada paciente, consideradas T1 (inicial), T2 (final) e T3 (longo tempo pós-tratamento). As telerradiografias utilizadas deveriam ser tomadas com os lábios em repouso e na posição de máxima intercuspidação habitual, com o auxílio do cefalostato de Broadbent (BROADBENT, 1931), seguindo as normas técnicas de obtenção e revelação preconizadas pela Disciplina de Radiologia da Faculdade de Odontologia de Bauru da Universidade de São Paulo.

Consideraram-se as correções das magnificações das telerradiografias, obtidas em diferentes aparelhos, as quais variaram entre 6 a $9,8 \%$, sendo realizadas pelo programa Dentofacial Planner (ARTUN; GAROL; LITTLE, 1996). 


\subsubsection{Elaboração do cefalograma e medição das telerradiografias}

Para a realização do cefalograma, uma folha de papel "ultraphan" de $0,07 \mathrm{~mm}$ de espessura, de $17,5 \times 17,5 \mathrm{~cm}$, foi adaptada em cada telerradiografia. $\mathrm{O}$ traçado anatômico e a demarcação dos pontos de referência dentoesqueléticos foram efetuados manualmente pela autora, com lapiseira de $0,5 \mathrm{~mm}$, sobre um negatoscópio, em sala escurecida. Após a realização dos traçados anatômicos, os mesmos foram conferidos por outro examinador, para garantir uma ampla margem de segurança quanto à exatidão dos traçados. Assim, o traçado anatômico e os pontos demarcados foram digitalizados em uma mesa digitalizadora Numonics AccuGrid XNT, modelo A30TL.F, acoplada a um microcomputador Pentium 166Mhz.

O programa utilizado para a medição das grandezas cefalométricas foi 0 Dentofacial Planner 7.2b, efetuando-se por meio do mesmo a correção da magnificação da imagem radiográfica.

\subsubsection{Traçado anatômico}

Foram delimitadas as seguintes estruturas dentoesqueléticas e do perfil tegumentar:

- contorno do perfil tegumentar;

- perfil do osso frontal e dos ossos nasais;

- contorno da sela túrcica;

- contorno do meato acústico externo;

- limite posteroinferior da cavidade orbitária;

- maxila, partindo da espinha nasal posterior estendendo-se pelo assoalho da fossa nasal limitando-se anteriormente na espinha nasal anterior, e incluindo o perfil alveolar anterior e o palato duro;

- mandíbula: contorno da cortical externa da sínfise, borda inferior do corpo, borda posterior do ramo ascendente e o côndilo mandibular;

- incisivos centrais permanentes superiores e inferiores;

- primeiros molares permanentes superiores e inferiores.

Para todas as estruturas bilaterais traçou-se a média. 


\subsubsection{Demarcação dos pontos cefalométricos de referência (FIGURA 4)}

Os pontos de referência anatômicos foram demarcados seguindo as especificações de determinados autores (JACOBSON, 1975; KROGMAN; SASSOUNI, 1957; LEGAN; BURSTONE, 1980; MARTINS, D.R.E.A., 1998; MCNAMARA, J.A., JR., 1984; RICKETTS, 1975; RIOLO, 1974; SCHEIDEMAN, 1980; STEINER, 1962).

1. S (sela túrcica): ponto mais central da concavidade óssea da sela túrcica;

2. N (násio): intersecção da sutura internasal com a sutura frontonasal;

3. Or (orbitário): a média dos pontos mais inferiores das margens inferiores das órbitas;

4. ENA (espinha nasal anterior): ponto mais anterior da espinha nasal anterior;

5. ENP (espinha nasal posterior): ponto mais posterior do palato duro;

6. Ponto A (subespinhal): ponto mais profundo na concavidade do contorno anterior da maxila;

7. Ponto B (supramentoniano): ponto mais profundo da concavidade anterior da mandíbula;

8. P (pogônio): ponto mais anterior do contorno do mento ósseo;

9. Gn (gnátio): ponto mais anteroinferior do contorno do mento ósseo, determinado pela bissetriz do ângulo formado pelos planos mandibular (Go$\mathrm{Me}$ ) e pela linha facial (N-Pog);

10. Me (mentoniano): ponto mais inferior da sínfise mentoniana; 
11.Go (gônio): ponto determinado pela bissetriz do ângulo formado pelas tangentes às bordas posterior e inferior da mandíbula;

12.Po (pório anatômico): ponto mais superior do meato acústico externo;

13.Co (condílio): ponto mais posterosuperior dos côndilos mandibulares;

14.BIS (borda do incisivo superior): ponto mais inferior da borda incisal do incisivo central superior;

15. AIS (ápice do incisivo superior): ponto mais superior do ápice radicular do incisivo central superior;

16. BII (borda do incisivo inferior): ponto mais superior da borda incisal do incisivo central inferior;

17. All (ápice do incisivo inferior): ponto mais inferior do ápice radicular do incisivo central inferior;

18.SMPMS (superfície mesial do primeiro molar superior): ponto mais anterior da coroa do primeiro molar permanente superior;

19.CMPMS (cúspide mésio-vestibular do primeiro molar superior): ponto mais inferior da cúspide mésio-vestibular do primeiro molar permanente superior;

20.SMPMI (superfície mesial do primeiro molar inferior): ponto mais anterior da coroa do primeiro molar permanente inferior;

21.CMPMI (cúspide mésio-vestibular do primeiro molar inferior): ponto mais superior da cúspide mésio-vestibular do primeiro molar permanente inferior;

22. COM (contato oclusal molar): o ponto médio da superfície de intercuspidação dos primeiros molares; 
23.COPM (contato oclusal pré-molar): ponto médio da superfície de intercuspidação dos primeiros pré-molares ou dos primeiros molares decíduos;

Além desses pontos, estritamente relacionados com estruturas anatômicas, construíram-se pontos para efeitos de digitalização:

24.Pogperp (ponto pogônio perpendicular): ponto localizado arbitrariamente ao nível dos incisivos superiores, porém perpendicular ao plano Go-Me, a partir do ponto Pog.

25.ENAperp (ponto espinha nasal anterior perpendicular): ponto localizado arbitrariamente ao nível dos incisivos inferiores, porém perpendicular ao plano palatino, a partir do ponto ENA;

26.Ba (básio): ponto localizado na região posteroinferior do osso occipital na margem anterior do forame magno;

27.Pt (pterigóideo): o ponto localizado na interseção das paredes posterior e superior da fissura pterigomaxilar;

28.CC (centro do crânio): ponto localizado na interseção da linha Ba-N e Pt-Gn.

\subsubsection{Linhas e planos de referência}

\subsubsection{Horizontais}

A. Linha SN: do ponto sela ao násio;

B. FH (plano horizontal de Francfort): do ponto pório ao orbitário;

C. PP (plano palatino): do ponto ENA ao ENP;

D. POF (plano oclusal funcional): do contato oclusal pré-molar ao contato oclusal molar; 
E. GoGn (plano mandibular): do ponto gônio ao gnátio;

F. GoMe (plano mandibular): do ponto gônio ao mentoniano.

\subsubsection{Verticais}

G. Linha NA: une o ponto násio ao ponto A;

H. Linha NB: une o ponto násio ao ponto B;

I. Linha BIS-AIS (longo eixo do incisivo superior): une os pontos correspondentes da borda incisal ao ápice dos incisivos centrais superiores;

J. Linha Bll-All (longo eixo do incisivo inferior): une os pontos correspondentes da borda incisal ao ápice dos incisivos centrais inferiores;

K. Linha Nperp: linha perpendicular ao plano de Francfort, passando pelo ponto násio;

L. Linha Pogperp: linha perpendicular ao plano mandibular Go-Me, passando pelo ponto pogônio;

M. Linha ENAperp: linha perpendicular ao plano palatino, passando pela espinha nasal anterior;

N. Linha Aperp - linha perpendicular ao plano de Francfort, passando pelo ponto A;

O. Linha AP - linha que passa pelos pontos A e P;

P. Plano CoGo: do ponto condílio ao ponto gônio. 


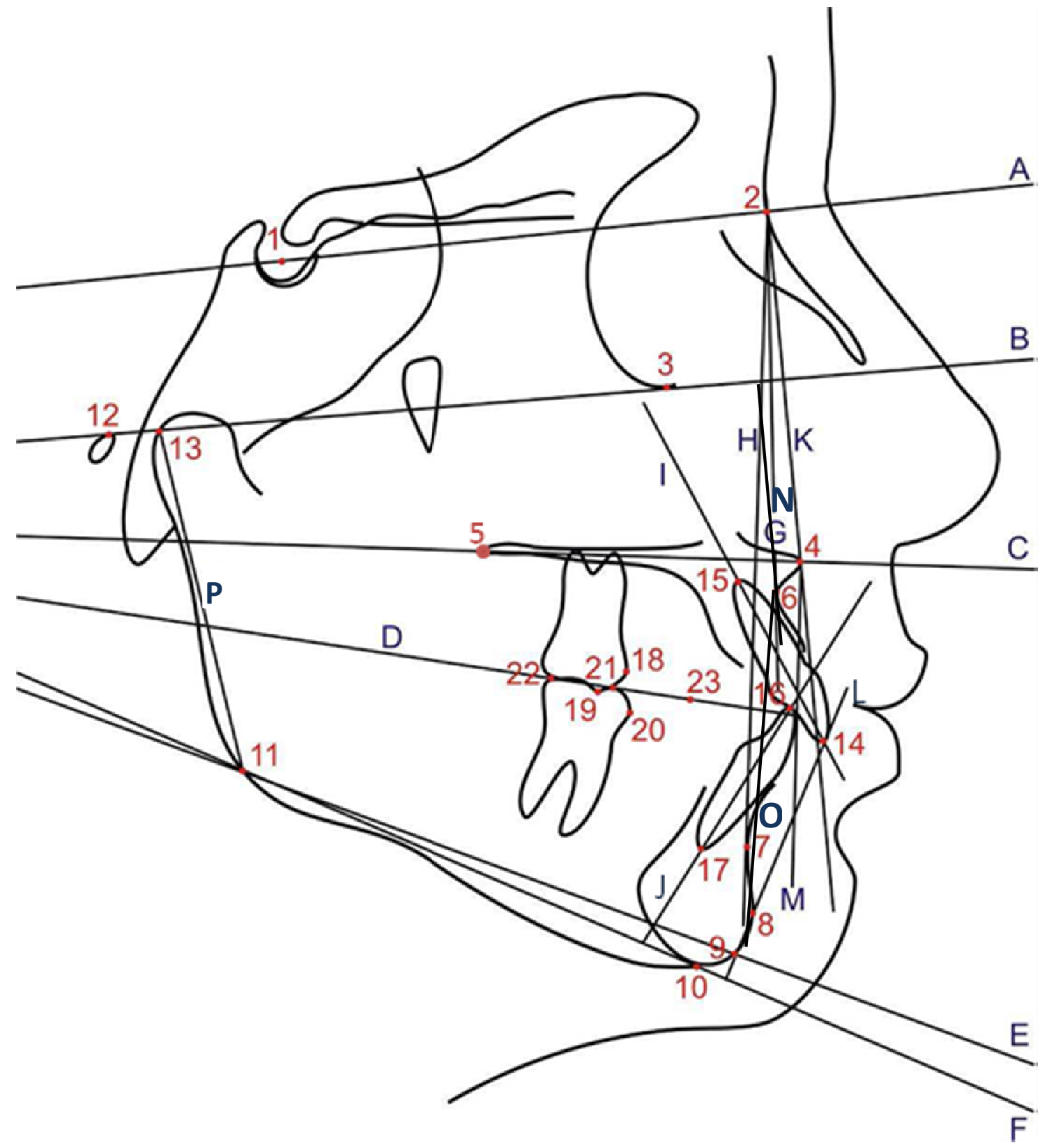

FIGURA 4: Pontos de referência, linhas e planos utilizados 


\subsubsection{Grandezas cefalométricas esqueléticas (FIGURA 5)}

\subsubsection{Maxilares}

1. SNA (ํ): ângulo formado pelas linhas $S N$ e NA. Indica a relação sagital da maxila em relação à base do crânio, e seu aumento indica um aumento da protrusão maxilar;

2. Co-A (mm): distância entre os pontos condílio e A. Representa o comprimento efetivo da maxila;

3. A-Nperp ( $\mathrm{mm})$ : distância entre o ponto A e a linha násio perpendicular. Define a posição sagital da maxila e seu aumento também indica um aumento da protrusão maxilar.

\subsubsection{Mandibulares}

4. SNB (ํ): ângulo formado pelas linhas SN e NB. Indica a relação sagital da mandíbula, em relação à base do crânio, e seu aumento indica um aumento da protrusão mandibular;

5. Co-Gn (mm): distância entre os pontos condílio e gnátio. Define o comprimento efetivo mandibular;

6. P-Nperp ( $\mathrm{mm})$ : distância entre o ponto pogônio e a linha násio perpendicular. Representa a posição sagital da mandíbula, e seu aumento indica um aumento da protrusão mandibular;

\subsubsection{Maxilomandibulares}

7. ANB (ํ): ângulo entre as linhas NA e NB. Representa o grau de discrepância sagital entre a maxila e a mandíbula; sua diminuição indica um melhor relacionamento intermaxilar; 
8. Wits $(\mathrm{mm})$ : distância entre as projeções perpendiculares dos pontos $A$ e $B$ sobre o plano oclusal funcional. Define 0 relacionamento sagital entre a maxila e a mandíbula e sua diminuição indica um melhor relacionamento intermaxilar;

9. Co-A/Co-Gn (mm): proporção entre os comprimentos maxilar e mandibular. Avalia o crescimento diferencial da mandíbula em relação à maxila.

\subsubsection{Padrão de crescimento}

10.FMA (ํ): ângulo formado pelos planos horizontal de Francfort e mandibular (GoMe). Define basicamente a orientação do padrão de crescimento facial;

11.SN.GoGn (o): ângulo formado pela linha SN e o plano mandibular GoGn. Utilizando-se de pontos cefalométricos diferentes, também define a orientação do padrão de crescimento facial;

12.SN.PP (ํ): ângulo formado pela linha $S N$ e o plano palatino. Indica 0 posicionamento da porção basal maxilar;

13.SN.Gn (o): ângulo formado entre a linha $\mathrm{SN}$ e a linha NGn. Indicador da tendência do padrão de crescimento;

14.AFAI (mm): distância entre os pontos espinha nasal anterior e mentoniano. Indica a altura do terço inferior da face.

15.S-Go (mm): Distância entre os pontos sela e gônio. Indica a altura posterior da face. 


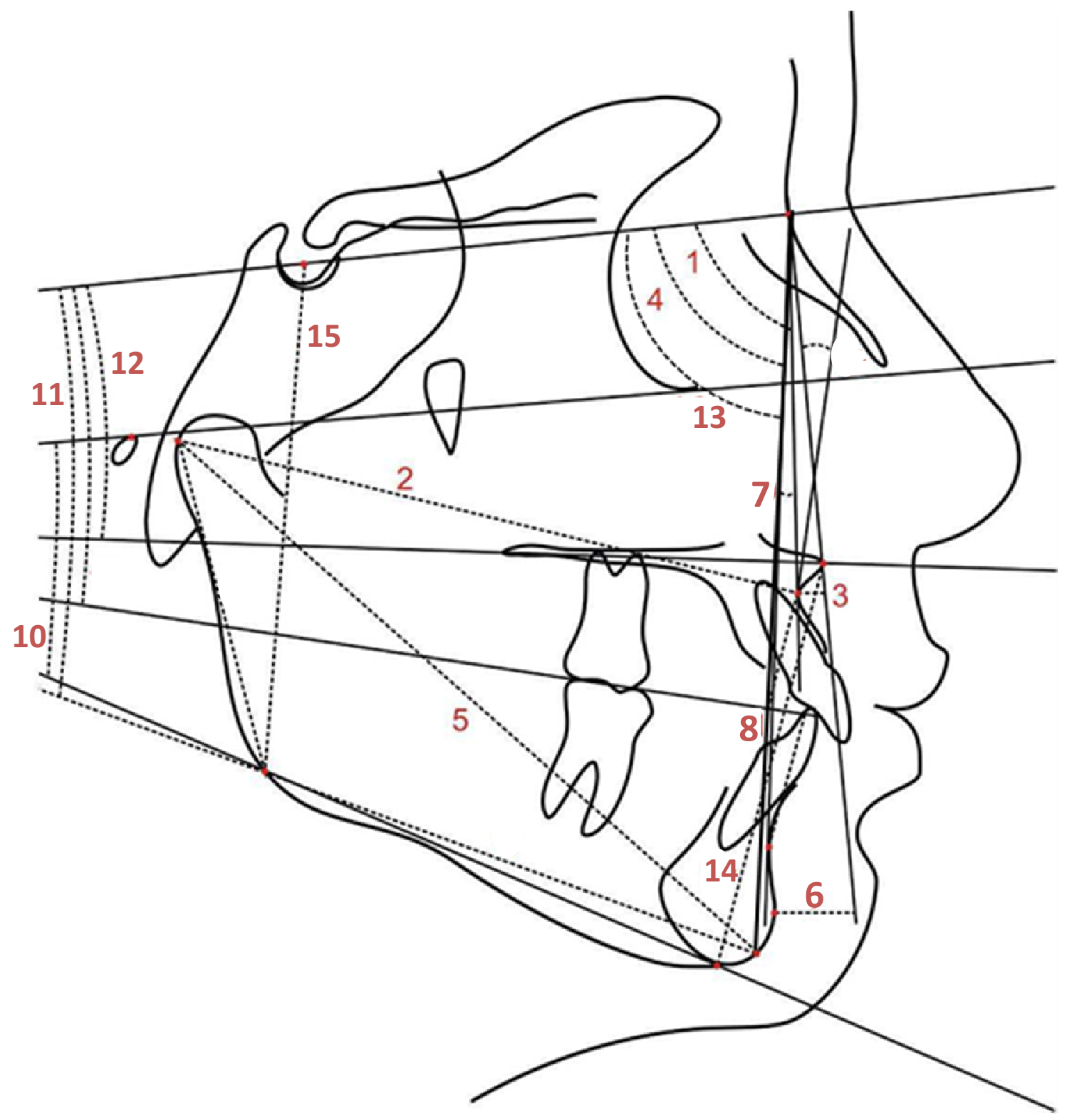

FIGURA 5: Grandezas cefalométricas esqueléticas 


\subsubsection{Grandezas cefalométricas dentárias (FIGURA 6)}

\subsubsection{Superiores}

1. 1.NA (ํ): ângulo entre o longo eixo do incisivo central superior e a linha NA. Define o grau de inclinação do incisivo central em relação à maxila e ao násio;

2. 1-NA (mm): distância entre o ponto mais anterior da coroa do incisivo central superior e a linha NA. Relaciona a posição sagital do incisivo superior em relação à maxila e ao násio e seu aumento indica uma protrusão do incisivo;

3. 1-PP $(\mathrm{mm})$ : distância entre a borda incisal do incisivo central superior e o plano palatino. Determina a altura do processo alveolar superior em sua região anterior;

4. 6-PP $(\mathrm{mm})$ : distância entre a cúspide mésio-vestibular do primeiro molar superior e o plano palatino. Avalia a altura do processo alveolar em sua região posterior;

\subsubsection{Inferiores}

5. IMPA (ํ): ângulo entre o longo eixo do incisivo central inferior e o plano mandibular GoMe. Indica a inclinação desse dente em relação à mandíbula;

6. 1.NB (ํ): ângulo entre o longo eixo do incisivo inferior e a linha NB. Relaciona a inclinação desse dente com a mandíbula e o násio;

7. 1-NB (mm): distância entre o ponto mais anterior da coroa do incisivo central inferior e a linha NB. Relaciona a posição sagital do incisivo inferior em relação à mandíbula e ao násio; 
8. 1-GoMe $(\mathrm{mm})$ : distância entre a borda incisal do incisivo central inferior e o plano mandibular. Determina a altura do processo alveolar inferior em sua região anterior;

9. 6-GoMe $(\mathrm{mm})$ : distância entre a cúspide mésio-vestibular do primeiro molar inferior e o plano mandibular. Determina a altura do processo alveolar inferior em sua região posterior.

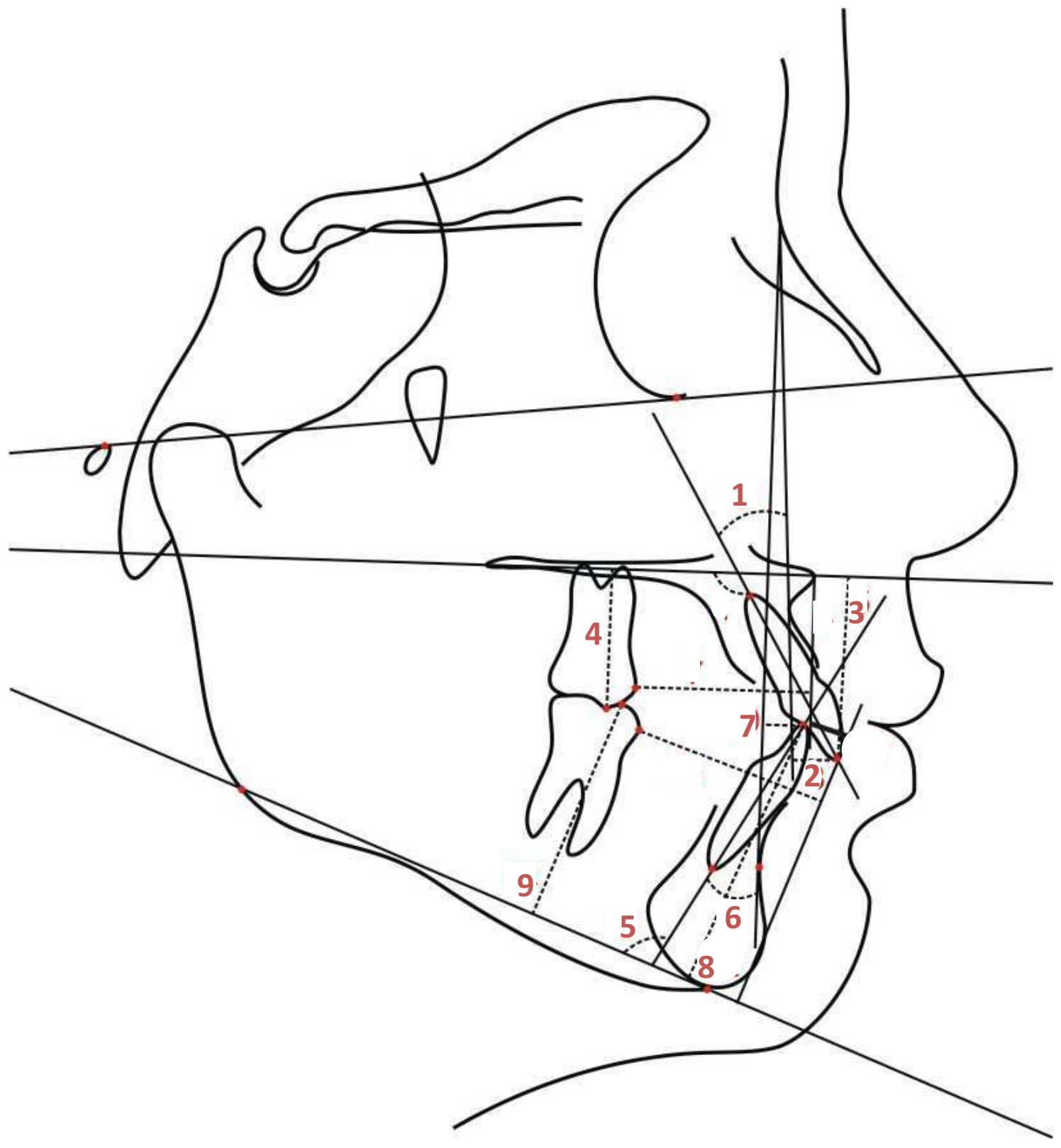

FIGURA 6: Grandezas cefalométricas dentárias superiores e inferiores 


\subsubsection{Relacionando-os entre si (FIGURA 7)}

1. TRESPASSE HORIZONTAL - TH (mm): distância da borda incisal do incisivo inferior à borda incisal do incisivo superior, medida paralelamente ao plano oclusal funcional.

2. TRESPASSE VERTICAL - TV (mm): distância da borda incisal do incisivo inferior à borda incisal do incisivo superior, medida perpendicularmente ao plano oclusal funcional.

3. RELAÇÃO MOLAR - Rel. molar $(\mathrm{mm})$ : distância da superfície mesial do primeiro molar superior à superfície mesial do primeiro molar inferior, medida paralelamente ao plano oclusal funcional. Seu aumento indica uma maior mesialização do molar inferior em relação ao superior. 


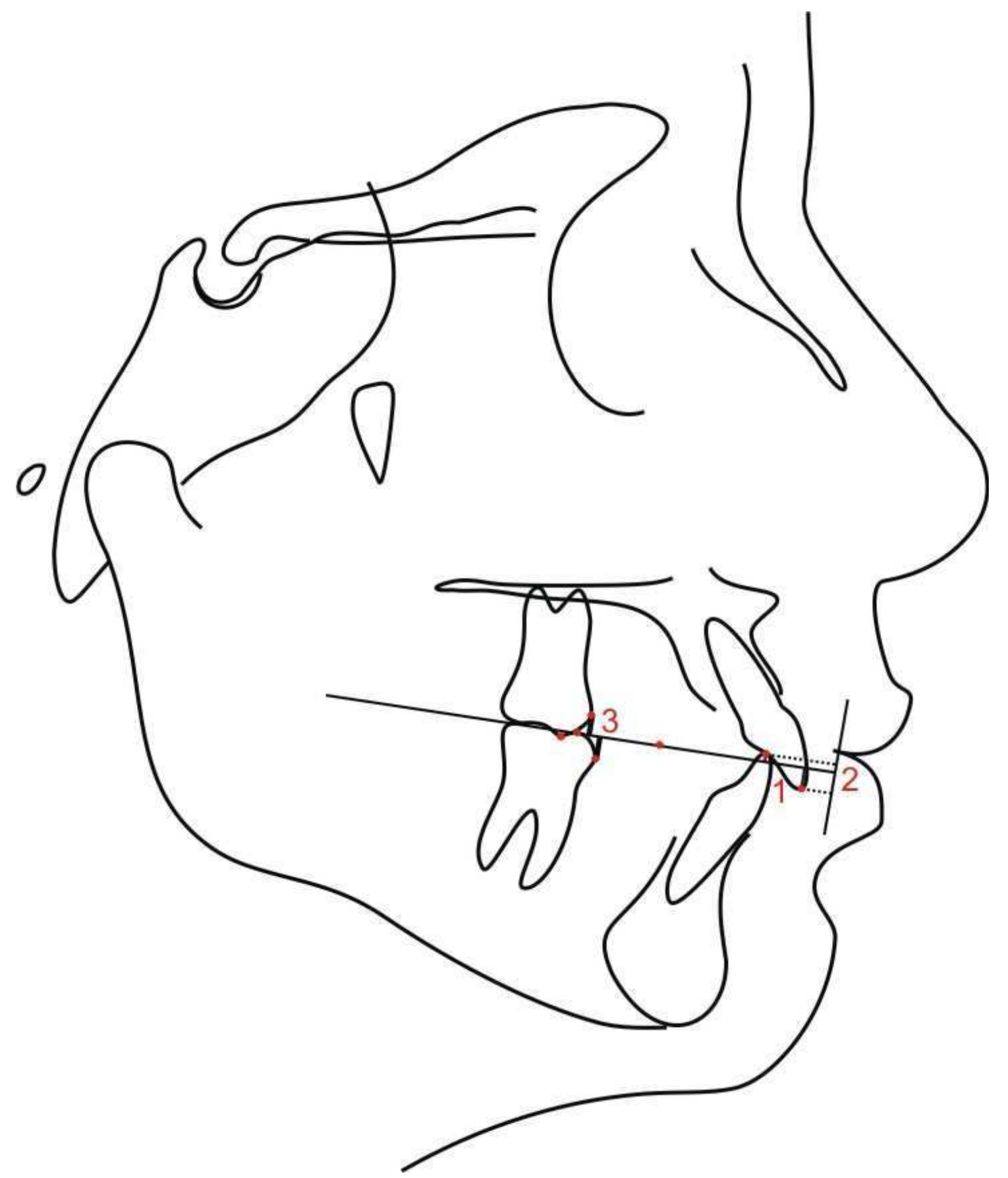

FIGURA 7: Grandezas cefalométricas referentes às relações dentárias 


\subsubsection{Grandezas cefalométricas referentes ao perfil tegumentar (FIGURA 8)}

1. ANL (ângulo nasolabial): ângulo formado por duas semirretas que passam pelos pontos derivados do pronasal (Prn') e lábio superior (Ls), respectivamente, apresentando como ponto comum o subnasal (Sn).

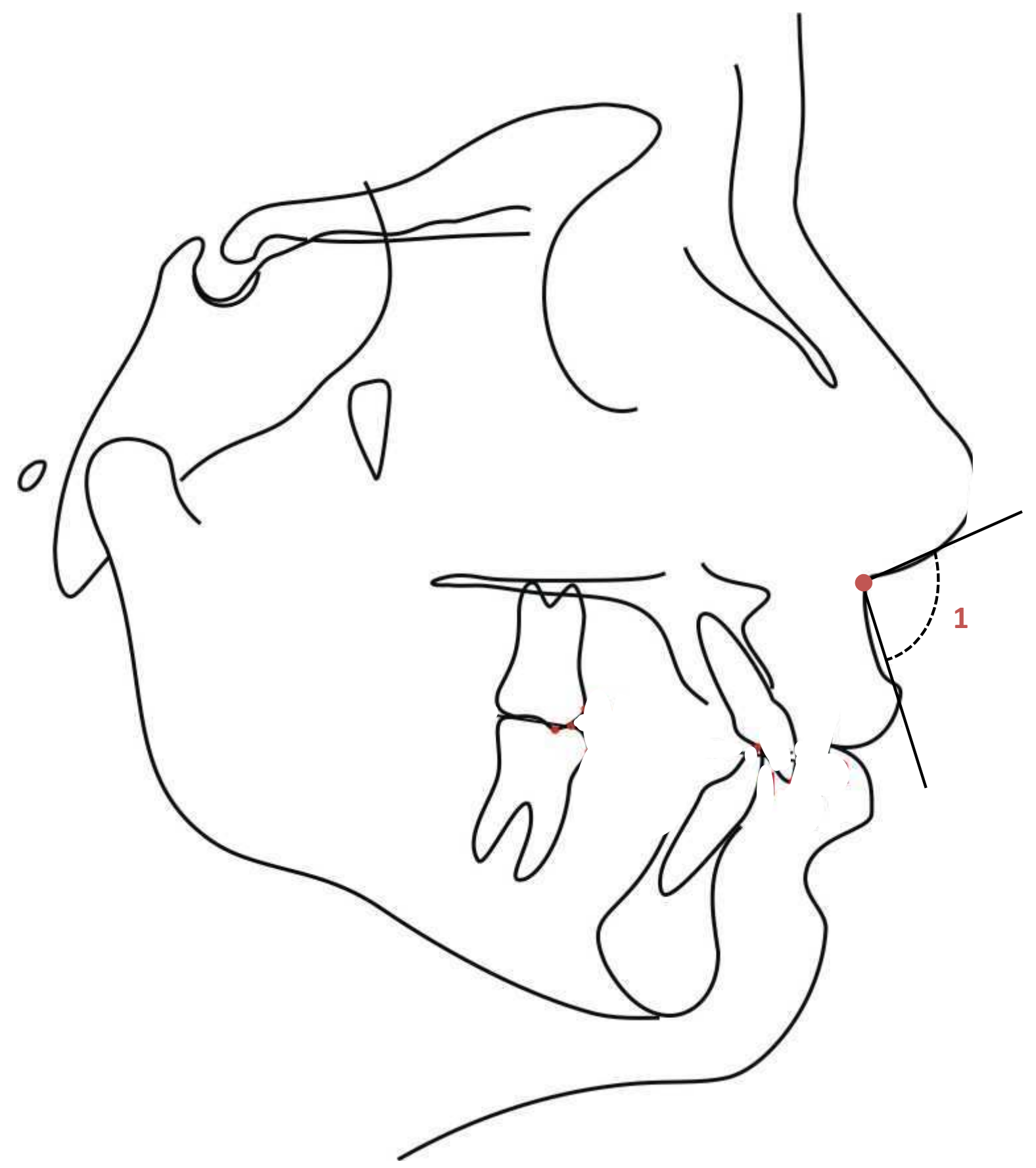

FIGURA 8: Grandezas cefalométricas referentes ao perfil tegumentar 


\subsection{Modelo de estudo}

Os modelos haviam sido previamente recortados e polidos segundo a técnica preconizada por Almeida et al. (1993). Todas as medidas realizadas foram obtidas a partir da utilização de um paquímetro digital da marca Mitutoyo (AL YAMI; KUIJPERS-JAGTMAN; VAN 'T HOF, 1999). A avaliação quantitativa das relações oclusais intra e interarcos, observadas nos modelos de gesso, realizou-se por meio do índice PAR nas fases: inicial (T1), final (T2) e longo tempo pós-tratamento (T3).

\section{Cálculo do índice PAR}

O índice PAR é calculado a partir de 11 componentes. São eles: segmento superior direito, segmento anterosuperior, segmento superior esquerdo, segmento inferior direito, segmento anteroinferior, segmento inferior esquerdo, oclusão posterior direita, oclusão posterior esquerda, trespasse horizontal, trespasse vertical e linha média.

\section{Segmentos Posteriores e Anterior}

Os arcos dentários são divididos em 3 segmentos: posterior esquerdo, posterior direito e anterior. Os escores são computados para o arco superior e inferior. A área de abrangência dos segmentos posteriores vai do ponto de contato anatômico mesial dos primeiros molares permanentes até o ponto de contato anatômico distal dos caninos; e, o segmento anterior, do ponto de contato anatômico mesial do canino de um lado até o ponto de contato anatômico mesial do lado oposto (FIGURA 9). 


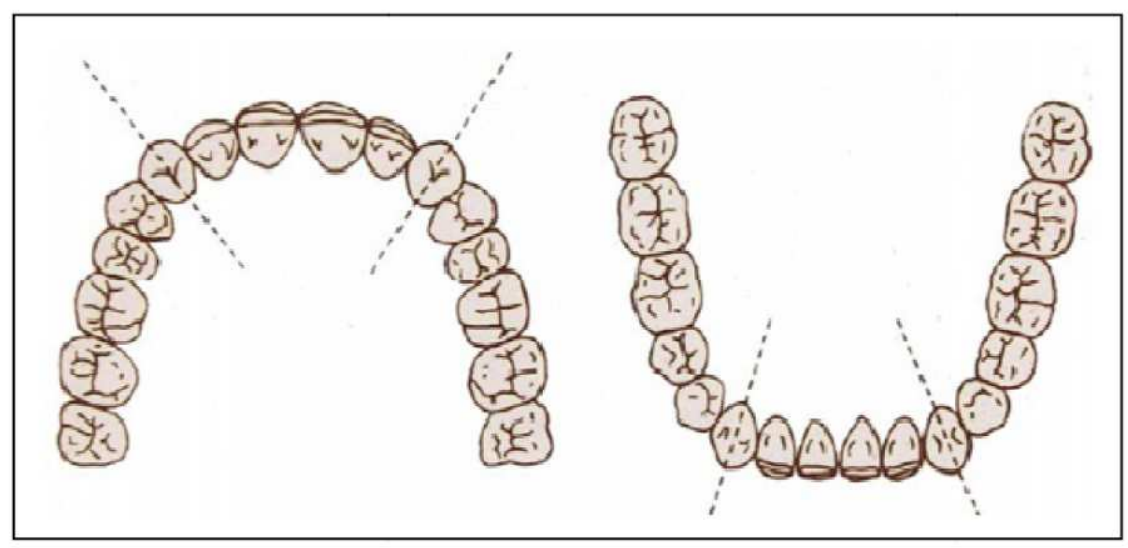

FIGURA 9: Divisão dos segmentos posteriores e anterior

As características oclusais avaliadas são: apinhamento, espaçamento e dentes impactados. As medidas são tomadas pela menor distância entre os pontos de contato de dentes adjacentes, paralela ao plano oclusal e os deslocamentos entre os primeiros, segundos e terceiros molares não são computados, por serem extremamente variáveis. Considera-se um dente impactado quando o espaço para este dente é menor ou igual a $4 \mathrm{~mm}$. Caninos impactados são computados no segmento anterior. Os escores dados para os deslocamentos encontram-se na TABELA 2.

\section{Oclusão Posterior}

Analisam-se separadamente os lados direito e esquerdo, nos 3 planos do espaço, e escores são dados às discrepâncias anteroposterior, vertical e transversa, de acordo com a TABELA 2. Em seguida, estes escores são somados e o valor final multiplicado por 2. Este componente se estende do canino até o último molar irrompido, seja ele o primeiro, o segundo ou o terceiro.

\section{Trespasse Horizontal}

São registrados os trespasses horizontais positivos e negativos, tomando-se como referência a face mais proeminente de qualquer incisivo. Este componente se estende do incisivo lateral esquerdo ao incisivo lateral direito. $O$ valor medido é transformado em escore e multiplicado por 5, de acordo com a TABELA 2. Durante 
essa medição, a régua ou instrumento utilizado, no caso, o paquímetro digital, deve manter-se paralelo ao plano oclusal e radial à linha do arco dentário.

\section{Trespasse Vertical}

O trespasse vertical é registrado em relação à proporção da coroa dos incisivos inferiores o que se encontra recoberto pelos incisivos superiores, tomandose como referência o dente com maior sobreposição. Em casos de mordida aberta avalia-se em milímetros o grau de sua severidade. O escore é fornecido pela TABELA 2 e multiplicado por 3.

\section{Linha Média}

Registra-se a discrepância da linha média superior em relação aos incisivos centrais inferiores, sendo que o grau de desvio determina o escore multiplicado por 3 (TABELA 2). 
TABELA 2: Critérios de aplicação dos escores para os componentes do índice PAR (RICHMOND et al., 1992a).

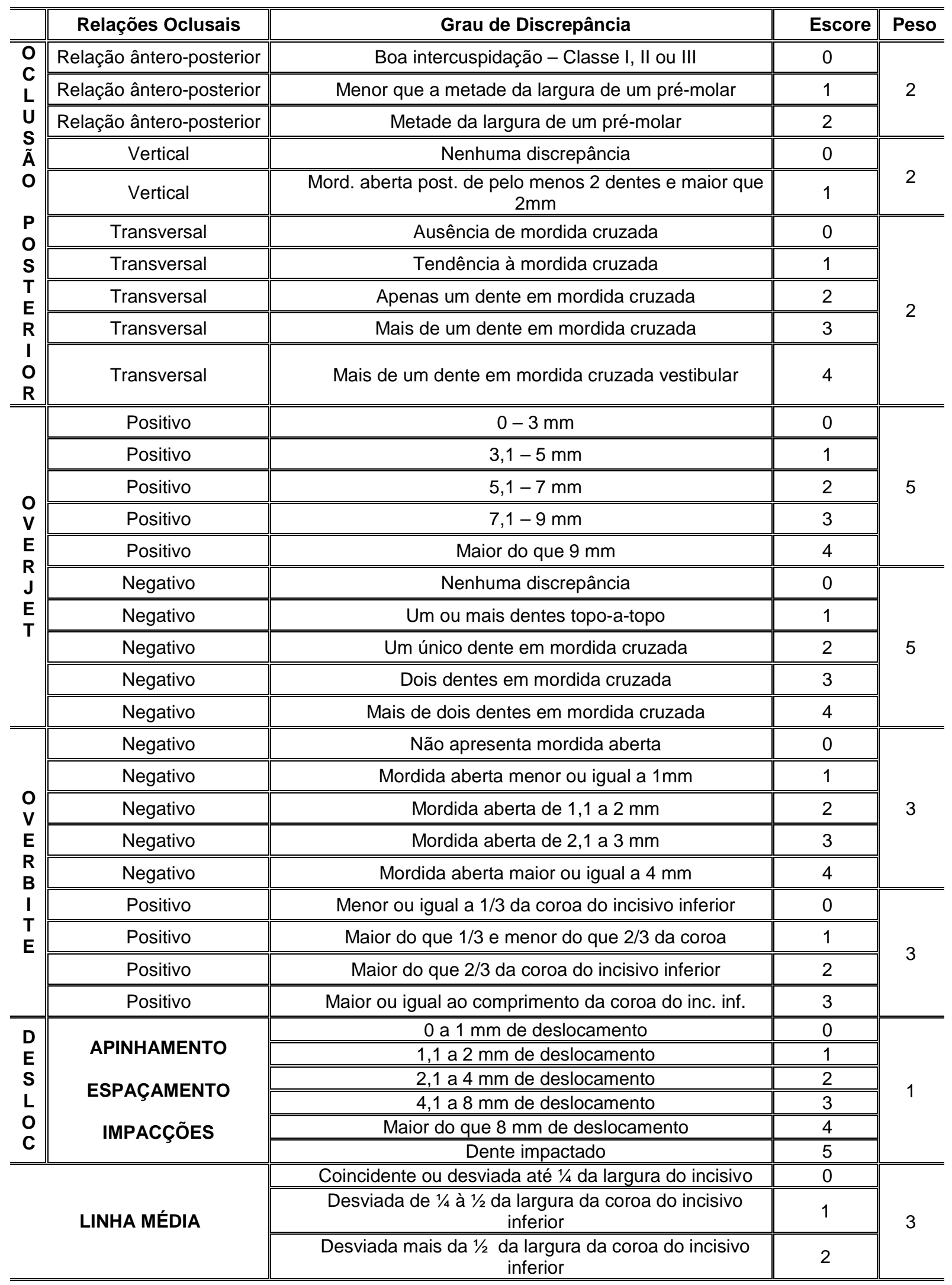


Antes de se realizar o somatório dos escores dos onze componentes deste índice, foram atribuídos pesos a cada um destes componentes conforme a proposta norte-americana vigente (DEGUZMAN et al., 1995) (TABELA 3). Um valor de índice PAR igual a 0 (zero) significa oclusão e alinhamento perfeitos, ao passo que valores elevados deste índice indicam a presença de severas discrepâncias em uma má oclusão. Quanto maior o valor numérico deste índice, maior o desvio da oclusão analisada em relação à normalidade.

TABELA 3: Pesos atribuídos aos diversos componentes do índice PAR segundo o sistema norte-amaricano (DEGUZMAN et al., 1995).

\begin{tabular}{l|c}
\multicolumn{1}{c|}{ Componentes do índice PAR } & Pesos \\
\hline Trespasse horizontal & $\times 5,0$ \\
\hline Trespasse vertical & $\times 3,0$ \\
\hline Linha média dentária & $\times 3,0$ \\
\hline Oclusão na região posterior & $\times 2,0$ \\
\hline Segmento ântero-superior & $\times 1,0$ \\
\hline Segmento ântero-inferior & $\times 0,0$ \\
\hline
\end{tabular}

Utilizando-se os critérios descritos no texto e os valores de escores especificados, calculou-se o índice PAR inicial (PAR1), PAR final (PAR2) e PAR longo tempo pós-tratamento (PAR3) a partir do somatório total dos resultados parciais de seus componentes para cada um dos 69 modelos.

A fim de avaliar a melhora decorrente do tratamento ortodôntico, calculou-se a diferença entre os valores inicial e final do PAR. A partir desta medida obteve-se, também, o porcentual de melhora expresso pelo índice PAR (BIRKELAND et al., 1997; RICHMOND et al., 1992a; RICHMOND et al., 1992b). Esse porcentual é um valor representativo da quantidade de melhora em relação à severidade inicial da má oclusão (\% melhora PAR = (PAR1-PAR2)/PAR1 X 100.

Para avaliar a recidiva decorrente do período de longo tempo pós-tratamento, calculou-se a diferença entre a melhora decorrente do tratamento ortodôntico e a estabilidade mantida até o respectivo período. Esse porcentual é um valor representativo da quantidade de recidiva em relação à melhora decorrente do tratamento ortodôntico (\% recidiva PAR $=($ PAR3-PAR2) / (PAR1-PAR2) X 100. 


\subsection{Análise Estatística}

\subsubsection{Erro do método}

Para a determinação da confiabilidade dos resultados, vinte e quatro radiografias foram selecionadas ao acaso, traçadas e digitalizadas novamente, pela mesma pesquisadora, após um intervalo de 30 dias. Desse modo, foi determinada a diferença entre a primeira e a segunda medição de cada telerradiografia. Depois disso, aplicou-se o teste t pareado, com o objetivo de avaliar a significância das diferenças apresentadas entre os dois traçados demonstrando, assim, o erro sistemático. Para a avaliação do erro casual, foi empregado o teste de Dahlberg, o qual demonstra a variação média entre a primeira e a segunda medição, com a seguinte fórmula:

$$
\mathrm{Se}^{2}=\Sigma \mathrm{d}^{2} / 2 \mathrm{n}
$$

No qual Se é a variação do erro, d representa a diferença entre a primeira e a segunda medição e n é o número de medições duplas.

\subsubsection{Estatística}

Os valores obtidos para as variáveis estudadas foram dispostos em quadros do programa Excel e encaminhados para a análise estatística, para se avaliarem as alterações decorrentes das fases: inicial (T1), final (T2) e longo tempo póstratamento (T3).

O cálculo do tamanho da amostra para a diferença de duas médias foi realizado considerando como poder de teste o valor de $80 \%$ e como coeficiente de confiança o valor de 95\%. Devido à ausência de relatos na literatura acerca de valores médios e desvios-padrão para as variáveis: relação molar e ANB, em pacientes que foram submetidos ao tratamento com o Bionator de Balters, associado ao aparelho ortodôntico fixo, após um período médio de 10 anos, utilizou-se os dados obtidos neste estudo para o respectivo cálculo, obtendo como resultados: 5, o número de pacientes necessários em cada fase avaliada, quando a relação molar foi a variável utilizada e 15 quando a variável ANB foi utilizada. Existe um trabalho, na 
literatura, com metodologia semelhante (JANSON, G. et al., 2004); entretanto, a terapia utilizada foi o aparelho extrabucal conjugado ao Ativador seguido da mecânica "Edgewise", após um período médio de 5 anos. Baseando-se nesse estudo e utilizando-se os valores médios e desvios-padrão para as mesmas variáveis anteriormente citadas, foram obtidos os seguintes valores: 16 e 9 pacientes, necessários em cada fase, respectivamente. Dessa maneira, o cálculo amostral foi realizado tendo sido baseado nesses dois trabalhos.

Empregou-se a estatística descritiva (média, desvio-padrão, e número) para a idade inicial, final, período de tratamento (T1-T2), período de longo tempo póstratamento (T2-T3), PAR inicial, PAR final e PAR longo tempo pós-tratamento. Para comparar as variáveis inicial (T1), final (T2) e longo tempo pós-tratamento (T3), utilizou-se a análise de variância para medidas repetidas - ANOVA, e, na obtenção de um resultado, estatisticamente significante, foi realizado o teste de Tukey.

Todos os testes foram realizados com o programa Statistica for Windows, adotando-se um nível de significância de 5\%. 

5 Resultados 



\section{RESULTADOS}

Os resultados deste trabalho estão apresentados sob a forma de tabelas. As variáveis foram estatisticamente significantes para $p<0,05$.

\subsection{Análise da normalidade das variáveis}

De acordo com o teste Kolmogorov-Smirnov (utilizado para verificar se todas as variáveis, das fases: inicial (T1), final (T2) e longo tempo pós-tratamento (T3), seguiam uma distribuição normal), verificou-se que nenhuma variável apresentou resultado estatisticamente significante, indicando que os testes estatísticos paramétricos podiam ser aplicados a essas variáveis.

\subsection{Resultados do erro intra-examinador}

Os valores referentes aos erros casuais e sistemáticos das variáveis iniciais (T1), finais (T2) e longo tempo pós-tratamento (T3) intraexaminador foram descritos na TABELA 4 e calculados por meio da aplicação do teste t pareado e da fórmula de Dahlberg. 
TABELA 4: Médias, desvios-padrão e resultados do teste $t$ pareado (erro sistemático) e do erro casual (Dahlberg) para a avaliação do erro intraexaminador nas variáveis iniciais, finais e longo tempo pós-tratamento.

\begin{tabular}{|c|c|c|c|c|c|c|}
\hline \multirow{2}{*}{ Variáveis } & \multicolumn{2}{|c|}{$1^{\text {a }}$ medição } & \multicolumn{2}{|c|}{$2^{a}$ medição } & \multirow{2}{*}{ Dahlberg } & \multirow{2}{*}{$\mathbf{P}$} \\
\hline & Média & D.P & Média & D.P & & \\
\hline SNA $(9)$ & 82,17 & 2,84 & 82,23 & 2,97 & 0,41 & 0,609 \\
\hline Co-A (mm) & 84,05 & 4,71 & 84,42 & 4,80 & 0,77 & 0,107 \\
\hline A-Nperp (mm) & $-1,45$ & 4,01 & $-1,19$ & 3,89 & 0,84 & 0,309 \\
\hline SNB $(9$ & 77,19 & 3,45 & 77,25 & 3,38 & 0,27 & 0,420 \\
\hline Co-Gn (mm) & 106,38 & 7,24 & 106,59 & 7,30 & 0,55 & 0,200 \\
\hline P-Nperp (mm) & $-9,64$ & 6,18 & $-9,32$ & 6,45 & 1,41 & 0,451 \\
\hline ANB $(9$ & 4,98 & 2,96 & 4,99 & 2,89 & 0,32 & 0,931 \\
\hline Wits (mm) & 3,60 & 2,45 & 3,68 & 2,44 & 0,59 & 0,688 \\
\hline Co-A/Co-Gn (mm) & 22,35 & 4,92 & 22,11 & 5,22 & 0,53 & 0,125 \\
\hline SN.GoGn ( 9 & 31,53 & 7,10 & 30,97 & 7,07 & 0,68 & $0,002^{*}$ \\
\hline NSGn $(9$ & 68,21 & 3,92 & 68,28 & 3,74 & 0,40 & 0,606 \\
\hline SN.PP ( $)$ & 6,08 & 3,24 & 6,48 & 3,59 & 0,70 & $0,046^{\star}$ \\
\hline FMA $(9$ & 27,91 & 6,44 & 27,22 & 6,62 & 1,11 & $0,026^{*}$ \\
\hline AFAl $(\mathrm{mm})$ & 64,87 & 5,49 & 64,90 & 5,63 & 0,55 & 0,860 \\
\hline S-GO (mm)(AFP) & 74,31 & 8,41 & 74,82 & 8,40 & 0,75 & $0,016^{*}$ \\
\hline 1-NA (mm) & 4,75 & 2,33 & 4,70 & 2,49 & 0,51 & 0,785 \\
\hline 1.NA $(9$ & 27,40 & 6,85 & 28,29 & 6,95 & 1,86 & 0,100 \\
\hline 1-APerp (mm) & 4,21 & 2,21 & 4,24 & 2,23 & 0,49 & 0,865 \\
\hline 1-PP (mm) & 27,41 & 3,11 & 27,46 & 3,18 & 0,31 & 0,597 \\
\hline 6-PP (mm) & 21,78 & 3,22 & 22,08 & 3,02 & 0,51 & $0,044^{*}$ \\
\hline 1-NB (mm) & 5,63 & 2,61 & 5,54 & 2,57 & 0,20 & 0,107 \\
\hline 1.NB $(9$ & 30,36 & 6,23 & 30,49 & 5,46 & 1,99 & 0,828 \\
\hline IMPA (9) & 98,81 & 5,37 & 99,40 & 5,47 & 2,05 & 0,337 \\
\hline 1-AP (mm) & 14,90 & 3,16 & 1,85 & 3,21 & 0,12 & 0,185 \\
\hline 1-GoMe (mm) & 40,09 & 3,30 & 40,05 & 3,49 & 0,56 & 0,786 \\
\hline 6-GoMe (mm) & 30,54 & 3,35 & 30,51 & 3,63 & 0,41 & 0,812 \\
\hline Rel. molar (mm) & $-1,68$ & 2,26 & $-1,77$ & 2,18 & 0,37 & 0,412 \\
\hline T.H. (mm) & 5,36 & 2,74 & 5,44 & 2,80 & 0,29 & 0,367 \\
\hline T.V. (mm) & 2,77 & 1,26 & 2,78 & 1,30 & 0,38 & 0,884 \\
\hline ANL $(9$ & 114,55 & 10,19 & 114,86 & 9,42 & 1,66 & 0,522 \\
\hline PAR & 12,96 & 13,22 & 13,04 & 12,90 & 1,04 & 0,788 \\
\hline
\end{tabular}

* Diferença estatisticamente significante para $\mathrm{P}<0,05$. 


\subsection{Resultados das variáveis cefalométricas}

A TABELA 5 representa as médias e os desvios-padrão das variáveis cefalométricas avaliadas nas fases: T1, T2 e T3, juntamente com os resultados do teste ANOVA para medidas repetidas e o teste de Tukey, quando necessário.

TABELA 5: Avaliação das alterações promovidas pelo tratamento e sua estabilidade Análise de Variância e teste de Tukey, considerando as variáveis cefalométricas.

\begin{tabular}{|c|c|c|c|c|}
\hline \multirow{2}{*}{ Variáveis } & Inicial (T1) & Final (T2) & Longo tempo PT (T3) & \multirow{2}{*}{$\mathbf{P}$} \\
\hline & Média (DP) & Média (DP) & Média (DP) & \\
\hline \multicolumn{5}{|c|}{ Componente maxilar } \\
\hline SNA ( $)$ & $82,59(2,75)^{A}$ & $81,63(2,74)^{\mathrm{A}}$ & $82,10(3,43)^{A}$ & 0,180 \\
\hline Co-A (mm) & $81,51(4,26)^{\mathrm{A}}$ & $82,83(5,40)^{\mathrm{A}}$ & $86,05(4,10)^{\mathrm{B}}$ & $0,000^{*}$ \\
\hline A-Nperp (mm) & $-0,20(2,62)^{A}$ & $-1,43(4,19)^{\mathrm{A}}$ & $-1,14(3,72)^{A}$ & 0,164 \\
\hline \multicolumn{5}{|c|}{ Componente mandibular } \\
\hline SNB (9) & $76,85(3,24)^{A}$ & $78,63(3,20)^{\mathrm{B}}$ & $79,16(3,88)^{\mathrm{B}}$ & $0,000^{*}$ \\
\hline Co-Gn (mm) & $99,64(4,79)^{\mathrm{A}}$ & $107,81(6,75)^{\mathrm{B}}$ & $112,07(6,32)^{\mathrm{C}}$ & $0,000 *$ \\
\hline P-Nperp (mm) & $-7,16(5,33)^{A}$ & $-5,11(7,88)^{A B}$ & $-4,27(7,91)^{\mathrm{B}}$ & $0,024^{*}$ \\
\hline \multicolumn{5}{|c|}{ Relação maxilomandibular } \\
\hline ANB ( 9 & $5,68(2,72)^{A}$ & $3,01(2,42)^{\mathrm{B}}$ & $2,93(2,73)^{\mathrm{B}}$ & $0,000^{*}$ \\
\hline Wits (mm) & $5,12(2,75)^{\mathrm{A}}$ & $1,20(2,03)^{\mathrm{B}}$ & $1,30(2,39)^{\mathrm{B}}$ & $0,000^{*}$ \\
\hline Co-A/Co-Gn (mm) & $18,13(4,13)^{A}$ & $24,66(4,95)^{\mathrm{B}}$ & $26,04(4,89)^{B}$ & $0,000^{*}$ \\
\hline \multicolumn{5}{|c|}{ Padrão facial } \\
\hline SN.GoGn (9) & $30,52(4,89)^{\mathrm{A}}$ & $30,47(6,47)^{A}$ & $28,43(6,96)^{\mathrm{B}}$ & $0,008^{*}$ \\
\hline NSGn ( $)$ & $66,97(3,25)^{A}$ & $67,02(3,63)^{A}$ & $66,46(4,16)^{\mathrm{A}}$ & 0,357 \\
\hline SN.PP (9) & $7,00(3,79)^{\mathrm{A}}$ & $6,36(3,71)^{\mathrm{A}}$ & $6,35(3,32)^{\mathrm{A}}$ & 0,571 \\
\hline FMA ( 9 & $26,18(4,49)^{\mathrm{AB}}$ & $26,58(6,35)^{\mathrm{A}}$ & $24,61(6,79)^{\mathrm{B}}$ & $0,032^{*}$ \\
\hline \multicolumn{5}{|c|}{ Componente vertical } \\
\hline AFAI (mm) & $58,32(4,72)^{\mathrm{A}}$ & $62,92(5,09)^{\mathrm{B}}$ & $64,70(6,28)^{\mathrm{C}}$ & $0,000^{*}$ \\
\hline S-Go (AFP) & $66,55(4,94)^{\mathrm{A}}$ & $73,27(6,58)^{\mathrm{B}}$ & $77,20(7,77)^{\mathrm{C}}$ & $0,000^{*}$ \\
\hline \multicolumn{5}{|c|}{ Componente dentoalveolar superior } \\
\hline 1-NA (mm) & $5,41(2,76)^{\mathrm{A}}$ & $4,96(2,74)^{\mathrm{A}}$ & $5,04(2,95)^{\mathrm{A}}$ & 0,706 \\
\hline 1.NA ( $)$ & $31,94(6,04)^{\mathrm{A}}$ & $27,68(6,56)^{\mathrm{B}}$ & $26,84(7,14)^{\mathrm{B}}$ & $0,000^{*}$ \\
\hline 1-APerp (mm) & $5,33(2,61)^{\mathrm{A}}$ & $4,22(2,71)^{\mathrm{A}}$ & $4,63(2,92)^{\mathrm{A}}$ & 0,092 \\
\hline 1-PP (mm) & $24,14(2,69)^{\mathrm{A}}$ & $26,15(3,02)^{\mathrm{B}}$ & $27,04(3,16)^{C}$ & $0,000^{*}$ \\
\hline 6-PP (mm) & $18,93(2,17)^{\mathrm{A}}$ & $21,16(2,65)^{\mathrm{B}}$ & $22,19(3,23)^{\mathrm{C}}$ & $0,000^{*}$ \\
\hline \multicolumn{5}{|c|}{ Componente dentoalveolar inferior } \\
\hline 1-NB (mm) & $3,37(2,40)^{\mathrm{A}}$ & $5,53(2,46)^{\mathrm{B}}$ & $5,00(2,38)^{\mathrm{B}}$ & 0,000 \\
\hline 1.NB (9) & $26,40(5,66)^{\mathrm{A}}$ & $31,06(5,71)^{\mathrm{B}}$ & $29,16(5,83)^{\mathrm{AB}}$ & $0,002^{*}$ \\
\hline IMPA (9) & $96,11(6,96)^{A}$ & $98,90(6,17)^{\mathrm{A}}$ & $98,51(7,33)^{\mathrm{A}}$ & 0,056 \\
\hline 1-AP (mm) & $-0,94(2,83)^{A}$ & $2,32(2,34)^{\mathrm{B}}$ & $2,03(2,54)^{\mathrm{B}}$ & 0,000 \\
\hline 1-GoMe (mm) & $36,59(3,00)^{\mathrm{A}}$ & $39,02(3,27)^{\mathrm{B}}$ & $40,30(3,53)^{\mathrm{C}}$ & $0,000^{*}$ \\
\hline 6-GoMe (mm) & $26,04(2,19)^{\mathrm{A}}$ & $29,85(2,74)^{\mathrm{B}}$ & $31,65(3,46)^{\mathrm{C}}$ & $0,000^{*}$ \\
\hline \multicolumn{5}{|c|}{ Relações dentárias } \\
\hline Rel. molar (mm) & $1,17(1,93)^{\mathrm{A}}$ & $-3,27(0,61)^{\mathrm{B}}$ & $-2,95(0,46)^{\mathrm{B}}$ & $0,000^{*}$ \\
\hline T.H. (mm) & $8,61(2,34)^{\mathrm{A}}$ & $3,22(0,70)^{\mathrm{B}}$ & $3,80(1,17)^{\mathrm{B}}$ & $0,000^{*}$ \\
\hline T.V. (mm) & $4,17(1,84)^{\mathrm{A}}$ & $2,27(0,97)^{\mathrm{B}}$ & $2,78(1,10)^{\mathrm{B}}$ & $0,000^{*}$ \\
\hline \multicolumn{5}{|c|}{ Tecidos moles } \\
\hline ANL ( 9 & $109,79(9,45)^{A}$ & $112,01(11,92)^{A}$ & $110,06(10,42)^{A}$ & 0,523 \\
\hline
\end{tabular}

* Diferença estatisticamente significante para $P<0,05$.

Valores com mesma letra na mesma linha não diferem estatisticamente pelo teste de Tukey $(\mathbf{P}, \mathbf{0}, 05)$. 


\subsection{Resultados das variáveis de modelo}

A TABELA 6 apresenta os resultados das médias e desvios-padrão para as variáveis: inicial (T1), final (T2) e longo tempo pós-tratamento (T3) do índice PAR, juntamente com os resultados do teste ANOVA para medidas repetidas e o teste de Tukey, quando necessário.

A TABELA 7 retrata a diferença entre os valores inicial e final do PAR, 0 porcentual de melhora expresso pelo índice PAR $(\%$ melhora PAR $=($ PAR1-PAR2) $/$ PAR1 $X 100$ e a recidiva decorrente do tratamento realizado $(\%$ recidiva PAR = (PAR3-PAR2) / (PAR1-PAR2) X 100.

TABELA 6: Avaliação das alterações promovidas pelo tratamento e sua estabilidade - Análise de Variância e teste de Tukey, considerando as variáveis de modelos.

\begin{tabular}{c|c|c|c|c}
\multirow{2}{*}{ Variáveis } & Inicial (T1) & Final (T2) & $\begin{array}{c}\text { Longo tempo Pós- } \\
\text { tratamento (T3) }\end{array}$ & \multirow{2}{*}{ P } \\
\cline { 2 - 4 } & Média (DP) & Média (DP) & Média (DP) & \\
\hline PAR & $30,13(5,90)^{A}$ & $5,39(3,39)^{B}$ & $5,60(4,55)^{B}$ & $0,000^{*}$
\end{tabular}

* Diferença estatisticamente significante para $\mathrm{P}<0,05$.

Valores com mesma letra na mesma linha não diferem estatisticamente pelo teste de Tukey $(P<0,05)$.

TABELA 7: Resultado das alterações do índice PAR durante o período de tratamento e durante o período de longo tempo pós-tratamento.

\begin{tabular}{c|c|c} 
Variáveis & Média & D.P. \\
\hline PARinicial - PARfinal & 24,73 & 6,64 \\
\hline$\%$ melhora PAR & $81,78 \%$ & 11,26 \\
\hline$\%$ recidiva PAR & $4,90 \%$ & 12,26
\end{tabular}


6 Discussão 



\section{DISCUSSÃO}

Para facilitar o entendimento dos resultados e interpretá-los, considerando as variáveis envolvidas neste estudo, torna-se de fundamental importância o esclarecimento sobre a amostra utilizada, metodologia empregada, sua precisão e os resultados obtidos.

\subsection{A amostra utilizada}

A seleção da amostra foi realizada com o intuito de avaliar a estabilidade do tratamento realizado com o aparelho Bionator de Balters seguido do aparelho fixo. Para tanto, apenas pacientes com má oclusão de Classe II submetidos a este protocolo de tratamento foram considerados. Portanto, um dos critérios básicos da seleção da amostra foi os pacientes apresentarem inicialmente má oclusão de Classe II de Angle, com relação molar de pelo menos meia Classe II (WHEELER et al., 2002). Em relação à severidade da discrepância anteroposterior, 14 pacientes apresentavam Classe II completa, 7 3/4 de Classe II e, 2 1/2 Classe II de Andrews (MOYERS et al., 1980). A relação molar foi corrigida por meio do uso do aparelho Bionator de Balters seguindo-se de instalação do aparelho ortodôntico fixo.

Uma amostra, de 23 pacientes, foi selecionada, a partir dos registros de arquivo da Disciplina de Ortodontia da Faculdade de Odontologia de Bauru, tratada, ao longo dos anos, por alunos do curso de pós-graduação strictu sensu. Além disso, ressalta-se que, a despeito dos esforços empregados para se obterem os registros completos de todos os pacientes tratados na Disciplina, alguns deles não possuíam uma documentação ortodôntica condizente com as necessidades específicas deste estudo.

Selecionaram-se apenas os casos que atenderam às exigências do trabalho, apresentando documentação ortodôntica completa, radiografias nítidas e modelos de estudo inicial, final e, pelo menos, 5 anos após o tratamento. Foram excluídos os casos em que as radiografias, com pouco contraste, dificultavam a visualização das estruturas anatômicas e os modelos de estudo danificados. 
A representatividade de uma amostra é importante para que os dados coletados sejam extrapolados para a população. Entretanto, o correto dimensionamento da amostra é uma tarefa complexa (VALLADARES-NETO; DOMINGUES; CAPELLOZZA-FILHO, 2000) e, muitas vezes, independe da boa vontade do pesquisador.

Evidentemente, amostras compostas por grandes números de pacientes são preferíveis, apesar de vários fatores influenciarem no tamanho das mesmas. Com o tempo, o número de pacientes de toda amostra tende invariavelmente a diminuir, seja por desistência do tratamento, seja por mudança de cidade, seja por falta de colaboração ou, seja, até mesmo, pela recusa do paciente em realizar a documentação necessária, especialmente, com relação aos controles póstratamento (BONDEMARK et al., 2007). Desse modo, os estudos longitudinais, apesar de grande importância no contexto científico, apresentam algumas limitações quanto ao tamanho da amostra. O número de pacientes utilizado pode ser considerado suficiente para conferir confiabilidade aos resultados, levando-se em consideração que outros trabalhos semelhantes empregaram amostras de tamanho compatível com o presente estudo (JANSON, G. et al., 2004; LEHMAN; ROMULI; BAKKER, 1988; MILLS, C.M.; MCCULLOCH, 2000; PANCHERZ, 1977). Ressalta-se que a amostra se encontra dentro dos limites preconizados por Houston, em 1983, o qual relata que, para a validade de qualquer estudo longitudinal, a amostra deve apresentar, no mínimo, 15 componentes. Portanto, a amostra utilizada neste estudo deve ser considerada satisfatória.

O período de controle de 5 anos pós-tratamento é favorável para a observação da estabilidade, segundo a metodologia utilizada, para a realização da revisão sistemática que versa sobre a estabilidade em longo prazo e satisfação do paciente. Bondemark et al., em 2007, utilizaram como principal critério para seleção dos estudos o período de observação maior que 5 anos. E Al Yami, KuijpersJagtman e Van't Hof, em 1999, afirmam que cerca de metade da recidiva total ocorre logo nos primeiros dois anos após o término do tratamento, com uma boa estabilidade da maior parte de suas características no período além de 5 anos após o tratamento.

Sabe-se que as alterações normais promovidas pelo crescimento podem ser confundidas com as do pós-tratamento em longo prazo. A comparação longitudinal entre os jovens que apresentam má oclusão de Classe II e os que apresentam 
oclusão normal tem sido o objetivo de várias pesquisas. Desse modo, nota-se que as principais diferenças são estabelecidas em estágios mais precoces do desenvolvimento, durante a pré-adolescência. Buschang et al., em 1988, observaram que a taxa de crescimento da mandíbula na má oclusão de Classe II, $1^{\text {a }}$ divisão era menor em comparação à oclusão normal (de 0,2 mm/ano menor para o gênero feminino e 0,4 mm/ano, para o masculino) dos 6 aos 10 anos. Porém, a partir dos 10 anos de idade, a velocidade de crescimento para a oclusão normal e a má oclusão de Classe II, $1^{\text {a }}$ divisão não apresentou diferença estatisticamente significante. Essas conclusões também são corroboradas por outros autores (BISHARA, S. E. et al., 1988).

A obtenção de um grupo controle de pacientes com má oclusão de Classe II, $1^{\text {a }}$ divisão, não submetido a tratamento, é extremamente difícil (DERMAUT; VAN DEN EYNDE; DE PAUW, 1992; PANCHERZ; FACKEL, 1990). Uma das razões para tal dificuldade é a necessidade de tratamento ortodôntico que a maioria desses pacientes apresenta, uma vez que esse tipo de má oclusão envolve problemas estéticos e funcionais. Além disso, as razões éticas, muito discutidas atualmente, tornam-se ainda mais difíceis a coletânea longitudinal desses dados, já que os pacientes seriam examinados apenas com o propósito de pesquisa (DERMAUT; VAN DEN EYNDE; DE PAUW, 1992). Por se tratar de um trabalho que avaliou a estabilidade de uma determinada terapia (Bionator de Balters associado ao aparelho ortodôntico fixo), após um período médio de 10 anos, a obtenção de um grupo controle compatível com a amostra avaliada seria demasiadamente dificultada.

O pico de crescimento pubescente ocorre por volta dos 12 anos para as meninas, e por volta dos 14 anos, para os meninos. A média de idade final, neste estudo, foi de 15,38 anos, e, a média de idade no período de longo tempo póstratamento foi de 24,99 anos. O principal objetivo do trabalho foi o de analisar a estabilidade após 10 anos de término do tratamento, quando os pacientes apresentavam idades entre 18,83 e 32,92 anos. Ressalta-se, portanto, que o estudo foi realizado após o surto de crescimento pubescente, e a avaliação da estabilidade ocorreu quando o mesmo já estava em fase de crescimento decrescente. Por conseguinte, a utilização de uma amostra para grupo controle não tratada nesta pesquisa não satisfaz os critérios necessários para a sua avaliação.

Os pacientes envolvidos nesta pesquisa, em sua grande maioria, utilizaram o aparelho extrabucal por, aproximadamente, $14 \mathrm{~h} / \mathrm{dia}$ durante todo o tratamento 
corretivo o que, provavelmente, contribuiu para a estabilidade encontrada. Após esse tratamento, os pacientes usaram a placa de Hawley superior por aproximadamente 1 ano e o 3X3 inferior até o momento da avaliação na fase longo tempo pós-tratamento.

\subsection{Metodologia}

O emprego de radiografias e modelos de estudo como meio de avaliação do paciente reúne a maior quantidade de informações relacionadas à estabilidade do tratamento ortodôntico (HAN et al., 1991). Segundo Ackerman e Proffit, em 1997, há uma pobre associação entre as características oclusais e a morfologia obtida nas telerradiografias.

Ao se utilizarem as telerradiografias como material de investigação científica, depara-se com vantagens e desvantagens como quando da utilização de qualquer material. Contudo, as telerradiografias são vantajosas por permitirem a avaliação: das características esqueléticas, da alteração do perfil facial, do padrão de crescimento craniofacial entre outras informações relevantes, que não são possíveis de serem obtidas pela análise de modelos ou clínica (EL-MANGOURY, 1979; PAE et al., 2001).

As telerradiografias que apresentavam qualidade inadequada, por terem sido tomadas sem supervisão, ou devido ao processamento, ou armazenamento insatisfatórios, por um longo período de tempo, foram excluídas da amostra, uma vez que este fator poderia aumentar a chance de ocorrência de erros durante os traçados (EL-MANGOURY, 1979). Desta forma, este estudo valeu-se apenas das telerradiografias que apresentavam qualidade satisfatória para serem traçadas com precisão.

O traçado cefalométrico confeccionado manualmente em sala escurecida foi conferido por um examinador antes da demarcação dos pontos a serem utilizados para a sua digitalização (ORMISTON et al., 2005; SADOWSKY et al., 1994). A medição digital das grandezas cefalométricas aperfeiçoou este trabalho, uma vez que, permitiu trabalhar-se com um maior número de dados, em um menor período de tempo, além de diminuir a probabilidade de ocorrerem erros durante a obtenção dos valores (BAUMRIND; FRANTZ, 1971). 
Para a realização deste estudo, utilizou-se o programa Dentofacial Planner, o qual é amplamente empregado e apresenta grande confiabilidade, pois realiza as medições com precisão de décimos de milímetros ou de graus, o que seria inviável de se obter com a medição manual (BISHARA, S.E. et al., 1995; PAQUETTE; BEATTIE; JOHNSTON JR., 1992). Além disso, permite que se realize a correção dos valores de magnificação das telerradiografias, possibilitando que as tomadas em diferentes aparelhos de raios $X$ possam ser precisamente comparadas (HOUSTON, 1983).

Os traçados das telerradiografias de um mesmo paciente eram realizados em sequência, para minimizar a imprecisão na determinação das estruturas anatômicas, uma vez que, a comparação de imagens, muitas vezes, era dificultada (HOUSTON, 1983).

Considerando os índices oclusais, o índice PAR foi selecionado dentre outros existentes na literatura pela comprovada validade em representar quantitativamente uma determinada condição oclusal, pela confiabilidade e reprodutibilidade dos resultados obtidos, por ter sido preconizado e largamente utilizado com o propósito de avaliar os resultados do tratamento ortodôntico e também por ser de aplicação simples e objetiva (AL YAMI; KUIJPERS-JAGTMAN; VAN 'T HOF, 1999; BIRKELAND et al., 1997; LINKLATER; FOX, 2002; ORMISTON et al., 2005). Além disso, o índice PAR possibilita uma avaliação não apenas da estabilidade do tratamento, mas também dos resultados do tratamento e severidade inicial. Essas características permitiram verificar tanto a quantidade e o porcentual de melhora obtida ao final do tratamento (BARROS, 2004), quanto o porcentual de recidiva no período de longo tempo pós-tratamento.

Para o cálculo do ganho obtido com este tipo de tratamento, considerou-se a porcentagem de melhora do tratamento, uma vez que, a possibilidade de alterações do PAR depende do seu valor inicial. Portanto, caso este possua valor baixo, a quantidade de alterações possíveis também será baixa (BARROS, 2004). A recidiva, por sua vez, está relacionada com a estabilidade das alterações obtidas durante 0 tratamento ortodôntico, sendo assim, com o cálculo da diferença entre a melhora decorrente do tratamento em relação à estabilidade mantida até o período de longo tempo pós-tratamento, obtém-se o porcentual de recidiva para a avaliação do índice de recidiva. 
O PAR possui limitações; restrições quanto ao seu uso podem ser encontradas, na literatura, e foram observadas no presente estudo. Como esse índice não avalia pequenas discrepâncias de posicionamento dentário, alterações discretas com o tratamento também não são detectadas. Por exemplo, se um caso apresenta trespasse vertical com cobertura de um a dois terços dos incisivos inferiores, e, com o tratamento ocorre melhora no seu relacionamento, mas ainda assim o trespasse vertical permanece nesta variação, nenhuma alteração é detectada pelo PAR (CLEMENTS et al., 2003). Os sistemas de pesos do PAR, para as diferentes más oclusões, preconizados por Hamdan e Rock, em 1999, não foram aplicados. Isso porque o sistema americano ou o britânico possui maior popularidade, e, assim, permite a comparação dos resultados do presente trabalho com os registrados na literatura a esse respeito.

A utilização do método radiográfico e a análise dos modelos de estudo proporcionaram uma metodologia bastante confiável para avaliação da estabilidade. Desta forma, cumpriu-se corretamente a proposta deste estudo e é, por isso, que se observa a ampla utilização destes métodos para a avaliação da estabilidade das correções ortodônticas na respectiva literatura (AL YAMI; KUIJPERS-JAGTMAN; VAN 'T HOF, 1999; DEVREESE et al., 2007; ELMS; BUSCHANG; ALEXANDER, 1996b; GLENN; SINCLAIR; ALEXANDER, 1987; WIESLANDER, 1993).

\subsection{Precisão da metodologia}

O estudo radiográfico cefalométrico, juntamente com a análise de modelos, apresenta-se como inestimáveis recursos para o diagnóstico, planejamento e acompanhamento ortodôntico. No entanto, para a utilização destas radiografias e modelos de estudo em pesquisas científicas, torna-se necessária a determinação do erro proveniente dos procedimentos envolvidos nas aferições dos modelos e dos traçados cefalométricos, bem como na demarcação e digitalização dos pontos.

Os erros metodológicos são classificados em dois tipos: erro sistemático e casual. Para determiná-los Houston (1983) sugeriu a duplicação das aferições em intervalos de tempo diferentes. Assim, de acordo com alguns autores (BAUMRIND; FRANTZ, 1971), foram selecionadas, ao acaso, 24 telerradiografias e 24 modelos provenientes das 3 fases estudadas (inicial, final e longo tempo pós-tratamento). Esses modelos foram novamente medidos e as radiografias foram retraçadas e 
redigitalizadas pela mesma pesquisadora, num intervalo de tempo de 4 semanas da mensuração inicial, segundo recomendações de Midtgard; Björk; Linder-Aronson (1974).

Os erros casuais e sistemáticos das grandezas foram testados pela fórmula de Dahlberg e teste t pareado e os resultados encontram-se dispostos na TABELA 4. Os erros casuais ocorrem, principalmente, pela dificuldade de identificar certos pontos cefalométricos ou pela falta de precisão na definição desses pontos (HOUSTON, 1983). Em geral, os erros casuais apresentaram-se reduzidos, e dentro dos valores aceitáveis recomendados por Houston e Sandler (1983), que se estende até $1 \mathrm{~mm}$ para as variáveis lineares e até $1,5^{\circ}$ para as angulares. $O$ maior significado dos erros casuais refere-se ao seu poder de aumentar o desvio-padrão das médias obtidas. Contudo, os erros casuais obtidos foram muito pequenos, não exercendo, portanto, grande influência no maior valor do desvio-padrão das médias.

O erro sistemático surge quando um parâmetro é insistentemente sub ou superestimado, como uma consequência da modificação da técnica de mensuração pelo pesquisador, após certo tempo, ou da tendenciosidade em direcionar os resultados de acordo com as próprias expectativas (HOUSTON, 1983). Contudo, apenas 5 das 30 variáveis cefalométricas avaliadas apresentaram diferença estatisticamente significante entre as duas medições: $S N$.GoGn $(p=0,002)$, SN.PP $(p=0,046), F M A(p=0,026)$, S-Go $(p=0,016)$ e 6-PP $(p=0,044)$ e as diferenças, entre a primeira e a segunda medição, foram, respectivamente, $0,56^{\circ}, 0,40^{\circ}, 0,69^{\circ}, 0,51 \mathrm{~mm}$ e $0,3 \mathrm{~mm}$. Esses valores das diferenças entre as duas medições foram de pequena magnitude e considerados clinicamente insignificantes.

Portanto, os resultados dos erros intra-examinador demonstraram que houve precisão na marcação e digitalização dos pontos cefalométricos, garantindo a reprodutibilidade e confiabilidade dos resultados obtidos nesta pesquisa.

\subsection{Resultados cefalométricos (TABELA 5)}

As medidas cefalométricas foram agrupadas em oito componentes: componente maxilar, componente mandibular, relação maxilomandibular, padrão facial, componente dentoalveolar superior e, inferior, as relações dentárias, e o componente tegumentar. O comportamento de cada componente foi avaliado como 
um todo para que as grandezas desse processo se dessem dentro de um contexto e não isoladamente.

\subsubsection{Componente maxilar}

A maxila geralmente encontra-se bem posicionada na má oclusão de Classe II, $1^{\text {a }}$ divisão não sendo, portanto, o principal fator responsável pelo desenvolvimento dessa entidade (CARTER, 1987; HENRIQUES et al., 1998; MAIA, 1998; MCNAMARA, J.A., JR., 1981; NGAN; BYCZEC; SCHEIK, 1997; PFEIFFER; GROBETY, 1975; RIEDEL, 1952). Contudo, diversos autores encontraram-na protruída em relação à base do crânio (ANDERSON, G.M., 1946; HENRIQUES et al., 1998; HENRY, 1957; MAIA, 1998; MAJ; LUZI; LUCCHESE, 1960; MARTIN, 1958; PROFFIT, 1993; ROSENBLUM, 1995; SERVOSS, 1975) e outros até retroposicionada (HENRIQUES et al., 1998; MCNAMARA, J.A., JR., 1981; SARHAN; HASHIM, 1994).

A maxila pode apresentar-se com tamanho aumentado e com uma forma atrésica, com os incisivos superiores inclinados para vestibular e os incisivos inferiores para lingual (ANGLE, E.H., 1899). Sabe-se que o comprimento maxilar aumenta gradativamente com a idade, dos 6 aos 18 anos, cerca de um grau ou um milímetro, fator observado, em ambos os sexos, por McNamara Jr (1984). Não obstante o padrão de crescimento normal da face se estabeleça quando a dentadura decídua se completa, este se mantém estável até os 18 anos de idade (BROADBENT, 1937; BRODIE, 1941, 1946). Janson (1990) ressaltou que o crescimento anteroposterior da maxila (Co-A) se estende após o final da puberdade nos jovens do sexo masculino e, no início, nos jovens do sexo feminino. Enfatizando o crescimento longitudinal da maxila, determinados autores (LINDER-ARONSON; WOODSIDE; DAIGLE, 1975) notaram que a taxa anual se encontrou entre 0,4 a 1,2 mm, com picos de aceleração ocorrendo por volta dos 10,5, 13,5 e 17,5 anos, e que o crescimento maxilar anteroposterior ocorreu ao longo do período da avaliação (dos 9 aos 33 anos), condizentes com os tipos sutural e aposicional de crescimento.

O aparelho utilizado para o tratamento da Classe II, $1^{\text {a }}$ divisão, especificamente nesta pesquisa, pode promover efeitos sobre a posição espacial da maxila, evidenciados por meio do ponto A (MCNAMARA, J.A., JR., 1984; MCNAMARA, J. A., JR.; BOOKSTEIN; SHAUGHNESSY, 1985; MILLS, J.R., 1991; 
URSI, W.J.S, 1993). Em função da utilização deste ponto, os autores supramencionados destacaram que o mesmo se apresenta sujeito às alterações na posição dos incisivos superiores, promovendo uma interpretação incorreta quanto à leitura da posição sagital maxilar.

Para a avaliação da posição da maxila, utilizou-se as grandezas cefalométricas SNA, Co-A e A-Nperp (FIGURA 10). Os resultados obtidos refletem que não houve diferença estatisticamente significante durante 0 tratamento, entretanto, no período de longo tempo pós-tratamento foi observado um aumento da variável Co-A, provavelmente, decorrente do crescimento longitudinal normal da maxila (FIGURA 10).

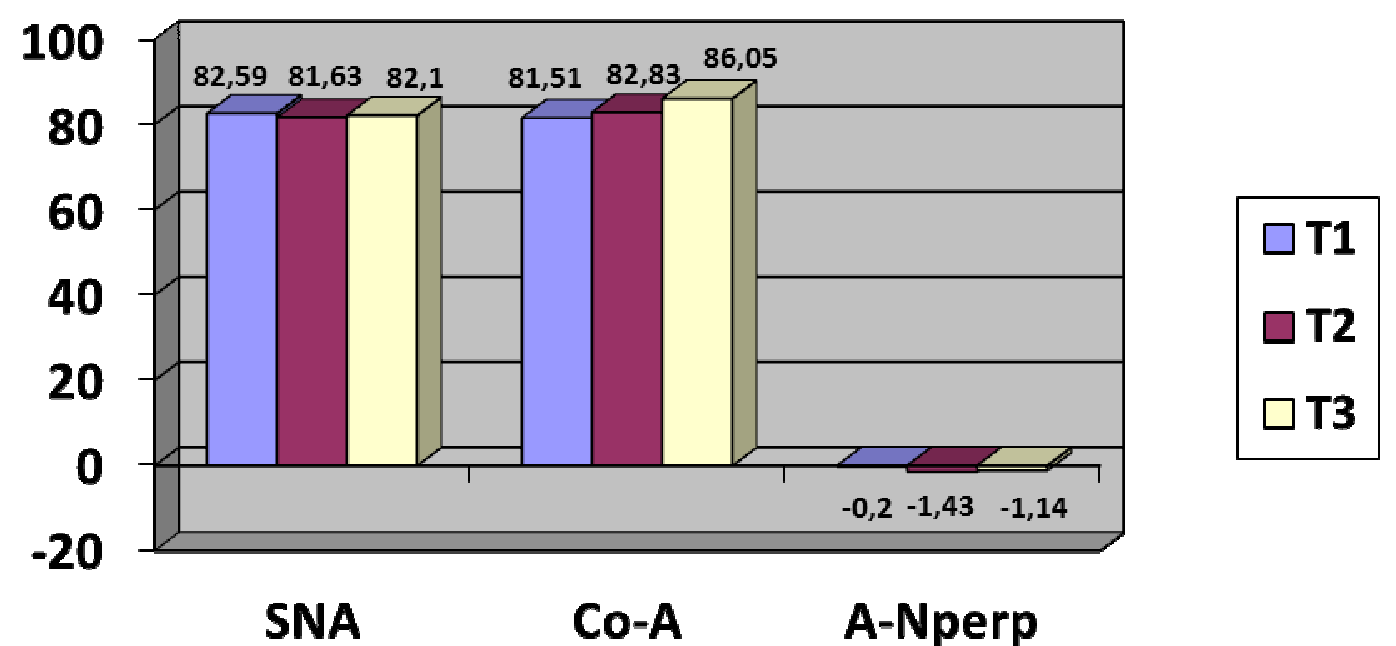

FIGURA 10: Variáveis do componente maxilar nas fases inicial (T1), final (T2) e longo tempo pós-tratamento (T3)

Resultados similares foram relatados pela maioria dos autores pesquisados (BOLMGREN; MOSHIRI, 1986; CHANG et al., 1989; COURTNEY; HARKNESS; HERBISON, 1996; GHAFARI; KING; TULLOCH, 1998; HASHIM, 1991; HENRIQUES, 1997; JANSON, I., 1977, 1978; JANSON, M.; HASUND, 1983; KEELING, 1998; MARTIN, 1958; MARTINS, J.C.R., 1997; TULLOCH; PHILLIPS; PROFFIT, 1998; TULLOCH; PROFFIT; PHILLIPS, 1997; WIESLANDER; LAGERSTROM, 1979), que não encontraram influência do Bionator sobre o desenvolvimento maxilar. Por outro lado, na literatura, alguns autores (VARGERVIK; HARVOLD, 1985) demonstraram que o Bionator promoveu uma restrição do crescimento para anterior da maxila, apontada pela diminuição do ângulo SNA. Esta redução, além de expressar mínima significância clínica, tem sido apontada como 
consequência não de uma retrusão da maxila, mas da inclinação para lingual dos incisivos superiores durante o tratamento (MILLS, J.R., 1991).

Conclui-se, frente à avaliação dos resultados, que a interceptação da má oclusão de Classe II, $1^{\text {a }}$ divisão por meio do aparelho Bionator de Balters, seguido do aparelho fixo, não promoveu um efeito de restrição sobre o desenvolvimento maxilar, observado através das variáveis SNA e A-Nperp no período de tratamento (T1-T2) e, por conseguinte, essas medidas permaneceram estáveis no período de longo tempo pós-tratamento (T2-T3) (FIGURA 10). Este resultado contraria o que ocorre com alguns aparelhos ortopédicos (ALMEIDA, M.R., 1997), que atuam de modo tão significante na maxila que recebem o rótulo de "Efeito AEB". No entanto, a variável Co-A, embora não tivesse apresentado um aumento no período de tratamento (T1-T2), o apresentou no período de longo tempo pós-tratamento (T2-T3) (FIGURA 10) em decorrência do crescimento longitudinal normal da maxila para a posterior acomodação dos $2^{\circ}$ e $3^{\circ}$ molares permanentes.

\subsubsection{Componente mandibular}

Embora exista uma extensa variabilidade dos componentes envolvidos na má oclusão de Classe II, $1^{\text {a }}$ divisão, o componente mandibular é considerado como um dos maiores responsáveis por esta má oclusão. A maioria dos trabalhos revisados demonstrou uma deficiência no desenvolvimento da mandíbula para anterior (ANGLE, E.H., 1907; BACCETTI et al., 1997; BISHARA, S.E. et al., 1997; BUSCHANG et al., 1988; CRAIG, 1951; DRELICH, 1948; FISK et al., 1953; GILMORE, 1950; HENRY, 1957; KARLSEN, 1994; KEAN, 1958; KLOCKE; NANDA; KAHL-NIEKE, 2002; LANGE et al., 1995; MARCONDES, 1963; MARTIN, 1958; NELSON, W.E.; HIGLEY, 1948; NGAN; BYCZEC; SCHEIK, 1997; PROFFIT, 1993; SANTOS, 2003), ou uma retrusão mandibular em relação à maxila e estruturas cranianas (ANDERSON, D.L.; POPOVICH, 1983; BACCETTI et al., 1997; BASS, 1982; BERTOZ et al., 2003; BISHARA, S.E., 1998; BRANDÃO; G.C.; L., 2001; CARTER, 1987; DE CASTRO, 1960; HENRIQUES et al., 1998; HENRY, 1957; KARLSEN, 1994; KING, 1962; MAIA, 1998; MARTIN, 1958; MCNAMARA, J.A., JR., 1981; NGAN; BYCZEC; SCHEIK, 1997; PFEIFFER; GROBETY, 1975; RENFROE, 1948; RIEDEL, 1952; SALZMANN, 1949; SANTOS, 2003; SERVOSS, 1975; URSI, W.; MCNAMARA, 1997). No entanto, outros pesquisadores (ANDERSON, G.M., 
1946; GILMORE, 1950; MAJ; LUZI; LUCCHESE, 1960; ROSENBLUM, 1995; ROTHSTEIN, T.; YOON-TARLIE, 2000; ROTHSTEIN, T.L., 1971) observaram que na Classe II, $1^{\text {a }}$ divisão, a mandíbula apresenta-se bem posicionada, divergindo da maioria dos estudos.

Neste estudo, avaliou-se o posicionamento mandibular em relação à base do crânio através das grandezas cefalométricas SNB e P-Nperp. O comprimento efetivo da mandíbula (Co-Gn) também foi analisado (FIGURA 11).

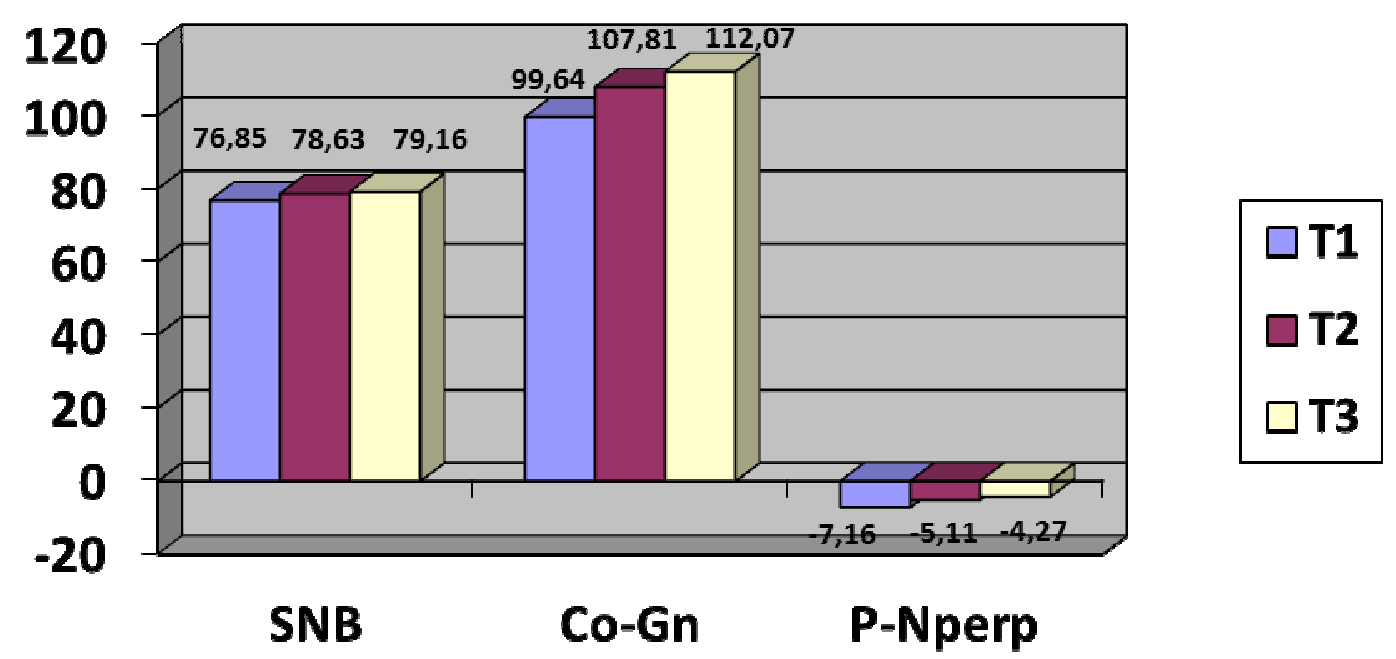

FIGURA 11: Variáveis do componente mandibular nas fases inicial (T1), final (T2) e longo tempo pós-tratamento (T3)

O crescimento mandibular normalmente ocorre no sentido posterosuperior deslocando a mandíbula para anterior e para baixo. No entanto, na má oclusão de Classe II, $1^{\text {a }}$ divisão, a mandíbula pode não crescer ou não se deslocar adequadamente. Interceptando a má oclusão por meio de aparelhos funcionais, objetiva-se estimular ou direcionar o crescimento mandibular. Assim, esperava-se um aumento de todas as grandezas correspondentes ao componente mandibular. Os resultados mostraram que as medidas SNB e P-Nperp (FIGURA 11) aumentaram, apresentando diferença estatisticamente significante no período de tratamento (T1-T2) e, permaneceram estáveis no período de longo tempo póstratamento (T2-T3).

Corroborando com os resultados obtidos, muitos autores, pesquisados na literatura (BASS, 1983b, 1983a; BISHARA, S.E.; ZIAJA, 1989; BOLMGREN; MOSHIRI, 1986; CHANG et al., 1989; CURA et al., 1996; DERRINGER, 1990; DEVINCENZO, 1991; FREITAS, B.V., 1996; FREUNTHALLER, 1967; GHAFARI; 
KING; TULLOCH, 1998; HENRIQUES, 1997; JAKOBSSON; PAULIN, 1990; JANSON, I., 1977, 1978; KEELING, 1998; LANGE et al., 1995; MAMANDRAS; ALLEN, 1990; MARTINS, J.C.R., 1997; MEACH, 1966; MILLS, J.R., 1991; OP HEIJ; CALLAERT; OPDEBEECK, 1989; SCHULHOF; ENGEL, 1982; THUER; INGERVALL; BURGIN, 1989; TSAMTSOURIS; VEDRENNE, 1983; TULLOCH; PHILLIPS; PROFFIT, 1998; TULLOCH; PROFFIT; PHILLIPS, 1997), demonstraram que o ângulo SNB aumentou com a utilização do Bionator.

Discordando dos resultados da presente pesquisa, outros autores (HARVOLD; VARGERVIK, 1971; HASHIM, 1991; NELSON, C.; HARKNESS; HERBISON, 1993; PANCHERZ, 1984; VARGERVIK; HARVOLD, 1985) não evidenciaram um incremento mandibular resultante do tratamento com o Bionator de Balters.

A dimensão mandibular, representada pela medida linear Co-Gn (FIGURA 11), aumentou tanto no período de tratamento (T1-T2) quanto no período de longo tempo pós-tratamento (T2-T3). Esse aumento pode ser justificado pelo crescimento longitudinal normal da mandíbula para a posterior acomodação dos $2^{\circ}$ e $3^{\circ}$ molares permanentes.

Concordando com os resultados deste estudo, diversos pesquisadores (ALMEIDA, M.R., 1998, 2000a, 2000b, 2003; ALMEIDA, M.R.; HENRIQUES; URSI, 2002; DERRINGER, 1990; FALTIN, K.J. et al., 2003; SCHULHOF; ENGEL, 1982) também observaram diferença significante no aumento do comprimento do corpo mandibular, avaliando pacientes com Classe II, tratados com o Bionator comparados a um grupo controle.

Para McNamara Jr.; Bookstein; Shaughnessy (1985) e Meach (1966), os aparelhos funcionais, além de exercerem influência na base apical, atuam também na musculatura, estimulando o crescimento condilar, aumentando, deste modo, o comprimento da mandíbula. Portanto, o aumento do comprimento efetivo da mandíbula (Co-Gn) parece ser uma unanimidade entre os autores pesquisados (ALMEIDA, M.R., 2000a; ALMEIDA, M.R.; HENRIQUES; URSI, 2002; BASS, 1983b, 1983a; BOLMGREN; MOSHIRI, 1986; CHANG et al., 1989; DERRINGER, 1990; DEVINCENZO, 1991; FREITAS, B.V., 1996; FREUNTHALLER, 1967; GHAFARI; KING; TULLOCH, 1998; HENRIQUES, 1997; JAKOBSSON; PAULIN, 1990; JANSON, I., 1977, 1978; KEELING, 1998; LANGE et al., 1995; MAMANDRAS; ALLEN, 1990; MILLS, J.R., 1991; SCHULHOF; ENGEL, 1982; TULLOCH; PHILLIPS; 
PROFFIT, 1998; TULLOCH; PROFFIT; PHILLIPS, 1997; WEBSTER; HARKNESS; HERBISON, 1996; WHEELER et al., 2002).

Concluindo este tópico, deve-se ressaltar que o Bionator, associado ao aparelho fixo, influenciou expressivamente o crescimento mandibular, promovendo uma protrusão e um aumento das dimensões mandibulares tanto no período de tratamento (T1-T2), verificado através das variáveis: SNB, Co-Gn e P-Nperp, quanto no período de longo tempo pós-tratamento (T2-T3), verificado pela variável Co-Gn (FIGURA 11).

\subsubsection{Relação maxilomandibular}

Em consequência às alterações ocorridas nos componentes maxilar e mandibular, a relação sagital entre as bases ósseas e a convexidade facial melhoraram significantemente.

O ajuste sagital entre as bases ósseas ocorre normalmente pelo crescimento diferencial entre a maxila e a mandíbula. Neste período, observa-se uma diminuição do ângulo ANB e uma tendência de melhora da convexidade facial, desde que os vetores de crescimento se processem em equilíbrio na direção anteroinferior.

Como era de se esperar, o ângulo ANB diminuiu, significantemente, possibilitando uma melhora no relacionamento maxilomandibular e na convexidade facial, e, foi observado, que esse valor permaneceu estável no período de longo tempo pós-tratamento (T2-T3) (FIGURA 12).

Este resultado é substanciado, na literatura, por diversos autores (ALMEIDA, M.R., 2000a, 2003; ALMEIDA, M.R.; HENRIQUES; URSI, 2002; CHANG et al., 1989; CURA et al., 1996; DERRINGER, 1990; HENRIQUES, 1997; JAKOBSSON; PAULIN, 1990; LANGE et al., 1995; MILLS, J.R., 1991; PANCHERZ, 1984; THUER; INGERVALL; BURGIN, 1989; TULLOCH; PHILLIPS; PROFFIT, 1998; TULLOCH; PROFFIT; PHILLIPS, 1997; WIESLANDER; LAGERSTROM, 1979), que verificaram com o uso do Bionator uma melhora significante no grau de discrepância maxilomandibular e no ângulo de convexidade esquelética.

A variável Witz, que também avalia a relação entre as bases ósseas, apresentou redução no período de tratamento (T1-T2) e se manteve estável no período de longo tempo pós-tratamento (T2-T3) (FIGURA 12). A significância estatística, nos períodos estudados, foi observada na fase de utilização do Bionator 
de Balters, seguido da mecânica com aparelho fixo, (T1-T2) e manteve-se estabilizada no período de longo tempo pós-tratamento (T2-T3) (FIGURA 12).

A relação Co-A/Co-Gn também foi avaliada e, observou-se um aumento da mesma no período de tratamento (T1-T2) e esta permaneceu estável no período de longo tempo pós-tratamento (T2-T3) (FIGURA 12). Embora esta medida tenha aumentado no período de tratamento, este aumento foi menor quando comparado ao normal, que ocorre durante o crescimento facial do paciente.

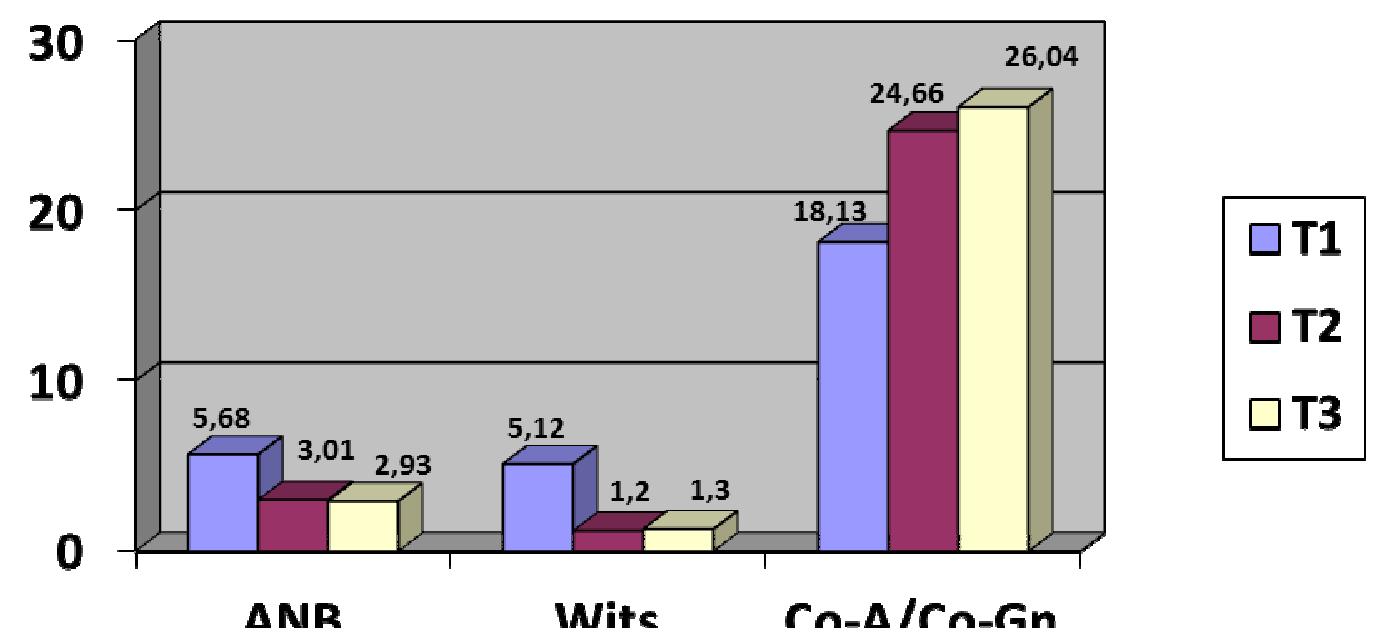

FIGURA 12: Variáveis da relação maxilomandibular nas fases inicial (T1), final (T2) e longo tempo pós-tratamento (T3)

Deve-se salientar que a alteração dessas variáveis pode resultar da combinação de vários efeitos nas estruturas dentoesqueléticas associados ao aproveitamento do crescimento normal craniofacial dos pacientes (URSI, W.J.S., 1996).

A expressiva efetividade na normalização da relação maxilomandibular, proporcionada pelo Bionator de Balters, seguido do aparelho fixo, ocorreu em função de um maior aumento na protrusão mandibular, bem como de efeitos dentoalveolares que podem ter influenciado nos resultados da pesquisa. É importante ressaltarmos também que, todas as alterações referentes à relação maxilomandibular, as quais demonstraram a normalização da mesma, permaneceram estáveis no período de longo tempo pós-tratamento (T2-T3) (FIGURA 12). 


\subsubsection{Padrão facial}

O comportamento do padrão de crescimento craniofacial influencia diretamente o aspecto no sentido horizontal da má oclusão de Classe II, interferindo indubitavelmente na sua correção. Lundström (1925), após compulsar extensamente a literatura sobre a Classe II, observou a existência de um padrão esquelético hereditário que dificulta o tratamento ortodôntico, e um padrão dentário de fácil tratamento. O estabelecimento do padrão de crescimento de cada indivíduo ocorre por volta dos 3 meses de vida, segundo Brodie (1941), mantendo-se durante toda a vida do indivíduo, enquanto que a velocidade de crescimento decresce em relação ao aumento da idade. Broadbent (1937) afirmou que o padrão de crescimento normal da face ocorre para frente e para baixo, estabelecendo-se na fase de dentadura decídua completa, permanecendo estável até os 18 anos de idade.

A má oclusão de Classe II, $1^{\text {a }}$ divisão caracteriza-se principalmente por exibir um comportamento dos vetores de crescimento, com predominância do componente vertical (BACCETTI et al., 1997; BUSCHANG et al., 1988; DRELICH, 1948; HENRIQUES et al., 1998; KARLSEN, 1994; MAIA, 1998; MCNAMARA, J.A., JR., 1981; NGAN; BYCZEC; SCHEIK, 1997). Não obstante a variação no crescimento condilar possa provocar uma rotação do corpo mandibular, um crescimento vertical maior na área dos molares pode rotacionar a mandíbula no sentido horário, aumentando a altura facial anteroinferior (SCHUDY, 1965). Janson (1990) notificou um aumento do terço inferior da face nos jovens de ambos os gêneros, embora os do gênero masculino finalizem o crescimento mais tardiamente.

Assim sendo, utilizou-se as grandezas cefalométricas: SN.GoGn, NSGn, SN.PP, FMA, AFAI e S-Go com a finalidade de identificar e quantificar as alterações no padrão vertical da face (FIGURAS 13 e 14). A medida SN.GoGn não demonstrou alteração significante no período de tratamento (T1-T2), o que denota que o padrão de crescimento não se alterou significantemente durante o mesmo. Entretanto, no período de longo tempo pós-tratamento (T2-T3) verificou-se uma tendência ao fechamento do ângulo do plano mandibular (FIGURA 13). 


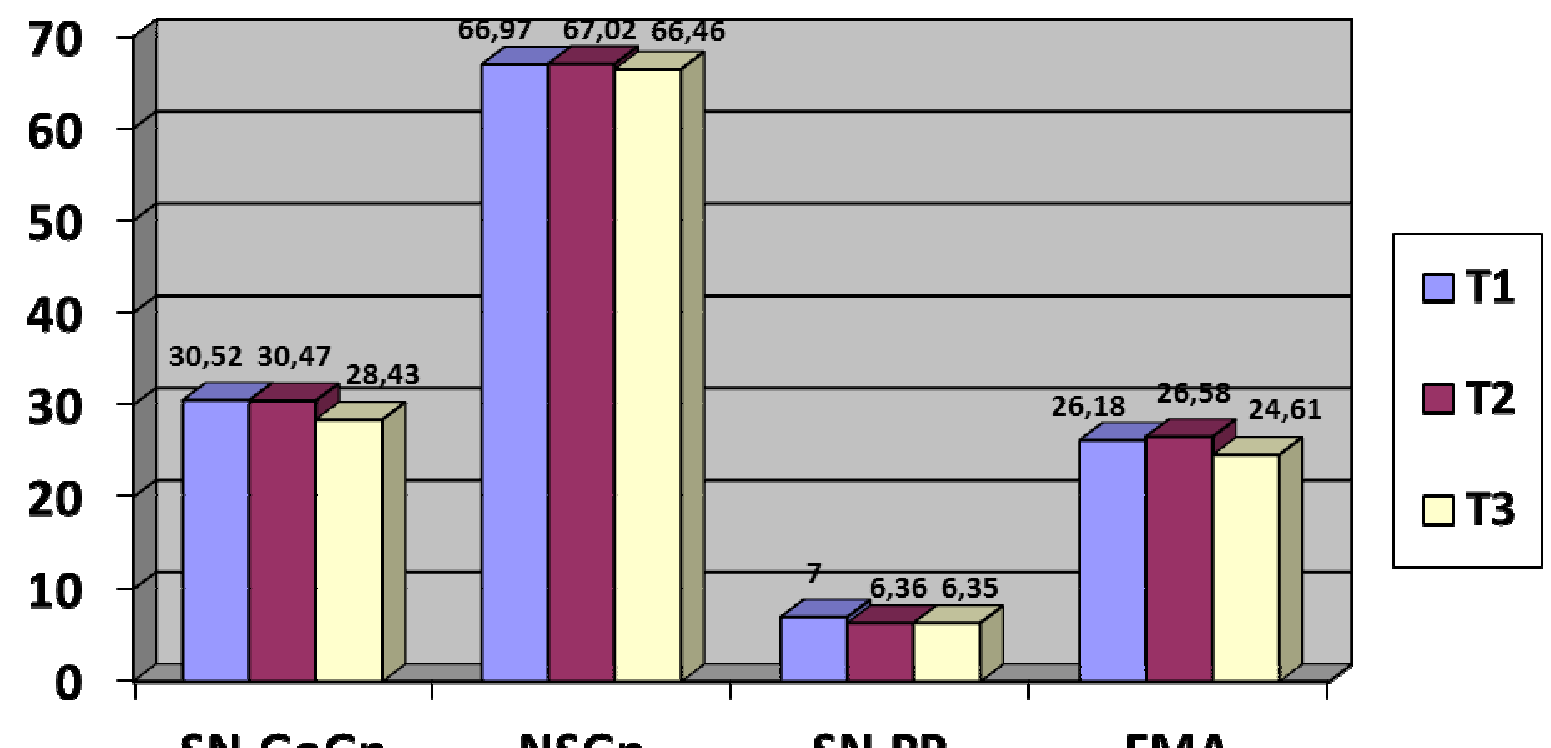

FIGURA 13: Variáveis do padrão facial nas fases inicial (T1), final (T2) e longo tempo pós-tratamento (T3)

Analisando a grandeza NSGn, observou-se que não houve alteração estatisticamente significante durante todo o período estudado (T1-T3) (FIGURA 13), fato este que comprova que o padrão do paciente tende a permanecer estável durante todo o crescimento.

Averiguando a grandeza SN.PP que mostra a inclinação do plano palatino em relação à base do crânio, evidenciou-se uma tendência de diminuição deste ângulo (FIGURA 13), embora os resultados não fossem estatisticamente significantes.

A variável FMA mostrou que não houve alteração significante no período de tratamento (T1-T2), o que demonstra que o padrão de crescimento não tende a se alterar. Entretanto, no período de longo tempo pós-tratamento (T2-T3) verificou-se o fechamento significante desse ângulo em relação à fase final do tratamento (FIGURA 13).

Os resultados de alguns pesquisadores (ALMEIDA, M.R., 1997, 1998; GIANELLY; ARENA; BERNSTEIN, 1984; JAKOBSSON; PAULIN, 1990; LANGE et al., 1995; MARTINS, D.R.E.A., 1998; MCNAMARA, J. A., JR.; BOOKSTEIN; SHAUGHNESSY, 1985; MCNAMARA, J. A., JR.; HOWE; DISCHINGER, 1990; RIGHELLIS, 1983; URSI, W.J.S, 1993) mostraram que os aparelhos funcionais não exerceram influência sobre o padrão de crescimento craniofacial. Em contraste, um 
aumento do padrão vertical decorrente dos aparelhos funcionais foi identificado nos resultados de Bolmgren; Moshiri (1986), Chang et al. (1989), Courtney; Harkness; Herbison (1996), Derringer (1990), Falck; Fränkel (1989), Meach (1966), Nelson; Harkness; Herbison (1993), Nielsen (1984), Schulhof; Engel (1982) e Wieslander; Lagerström (1979).

Concordando com a maioria dos autores, os resultados obtidos nesta pesquisa demonstraram que o aparelho estudado foi efetivo na manutenção do padrão de crescimento craniofacial. Este resultado provavelmente ocorreu devido ao curto período de tratamento em que os pacientes foram submetidos (T1-T2), de modo que não permitiu verificar alterações desfavoráveis, nestes fatores, no período de longo tempo pós-tratamento (T2-T3). Além disso, Brodie já mencionara, em 1941, que o padrão de crescimento é altamente estável durante a vida toda do indivíduo.

A altura facial anteroinferior (AFAl) também foi objeto de estudo na pesquisa (FIGURA 14), e como todos os jovens alojados na amostra apresentavam uma má oclusão de Classe II, esperava-se que o comportamento do crescimento craniofacial para frente e para baixo nesta má oclusão, denotasse um aumento desta mensuração. O presente estudo confirmou esse aumento, bem como a maioria das pesquisas que examinaram esta medida (ALMEIDA, M.R., 1997, 1998; CHANG et al., 1989; COURTNEY; HARKNESS; HERBISON, 1996; CREEKMORE; RADNEY, 1983; DERRINGER, 1990; GHAFARI; KING; TULLOCH, 1998; HENRIQUES, 1997; JAKOBSSON; PAULIN, 1990; KERR; HIRST, 1987; LANGE et al., 1995; MARTINS, J.C.R., 1997; MCNAMARA, J. A., JR.; HOWE; DISCHINGER, 1990; MILLS, J.R., 1991; NELSON, C.; HARKNESS; HERBISON, 1993; OP HEIJ; CALLAERT; OPDEBEECK, 1989; TSAMTSOURIS; VEDRENNE, 1983; URSI, W.J.S, 1993; VARGERVIK; HARVOLD, 1985; WEBSTER; HARKNESS; HERBISON, 1996; WIESLANDER; LAGERSTROM, 1979). 


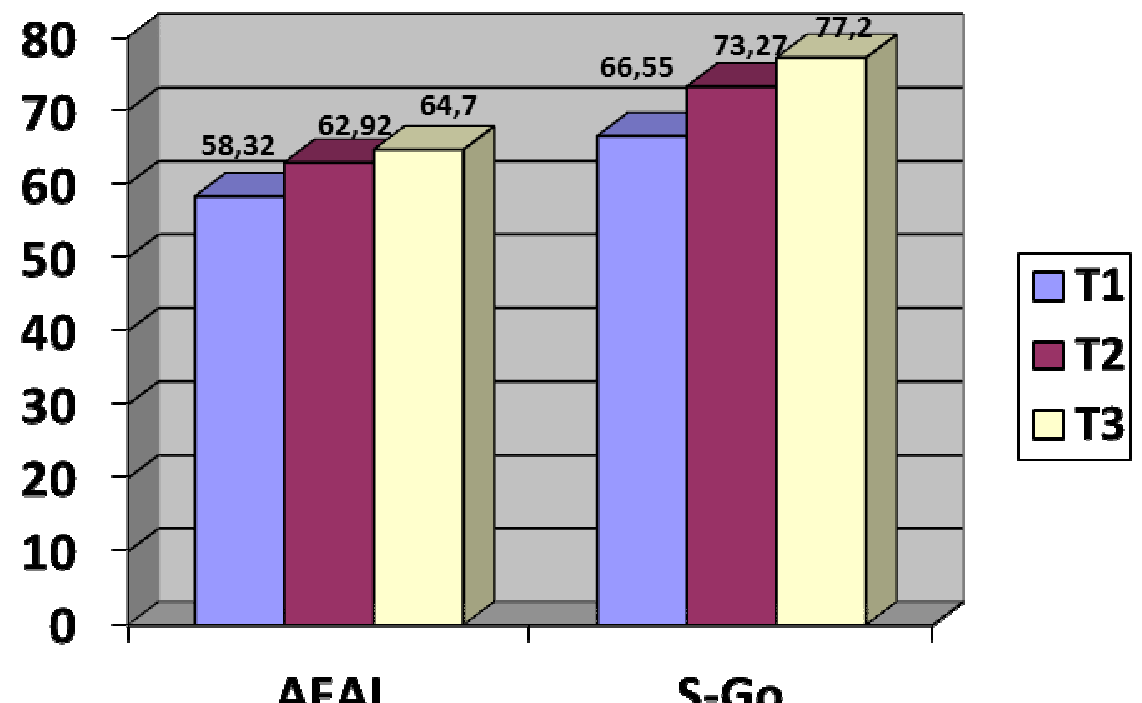

FIGURA 14: Variáveis do componente vertical nas fases inicial (T1), final (T2) e longo tempo pós-tratamento (T3)

Este maior aumento da AFAI, durante o tratamento (T1-T2) e no período de longo tempo pós-tratamento (T2-T3) (FIGURA 14), pode ser atribuído à abertura da mordida posterior que ocorre durante o avanço mandibular na elaboração da mordida construtiva, sendo mantida pela extrusão dos dentes posteroinferiores (TORUÑO, 1999).

A grandeza que avalia a altura facial posterior (S-Go) aumentou nos períodos estudados (T1-T2, T2-T3), denotando uma diferença estatisticamente significante entre os mesmos (FIGURA 14).

Portanto, os resultados demonstraram que a interceptação da má oclusão de Cl II, $1^{\text {a }}$ divisão com o Bionator de Balters, seguido da mecânica com o aparelho fixo, não alterou o padrão de crescimento e não aumentou demasiadamente as alturas faciais. Assim, pode-se inferir que o aparelho mencionado apresentou bons efeitos no sentido vertical, uma vez que apresentou um controle sobre o plano mandibular. 


\subsubsection{Componente dentoalveolar superior}

Segundo alguns autores (ALTEMUS, 1955; KEELING, 1998; MAJ; LUZI; LUCCHESE, 1960; MAMANDRAS; ALLEN, 1990; RIEDEL, 1952; SASSOUNI, 1970; WIESLANDER; LAGERSTROM, 1979), nas más oclusões de Classe II, $1^{\text {a }}$ divisão, os incisivos superiores normalmente apresentam-se vestibularizados e protruídos na base óssea, características que podem ser consideradas favoráveis para a aplicação dos aparelhos ortopédicos.

Os resultados desta pesquisa evidenciaram que o aparelho Bionator de Balters, associado ao aparelho ortodôntico fixo, promoveu alterações no posicionamento dos incisivos superiores (1.NA, 1-NA e 1-Aperp), e estas permaneceram estáveis no período de longo tempo pós-tratamento (T2-T3) (FIGURA 15). Os resultados obtidos mostraram a efetividade do tratamento, com os incisivos inclinados para lingual e retruídos, na base óssea, após a intervenção e a manutenção dessas características à longo tempo pós-tratamento (T3). Embora só tenha alcançado significância estatística a variável 1.NA, também observou-se uma redução das variáveis 1-NA e 1-Aperp clinicamente significante (FIGURA 15).

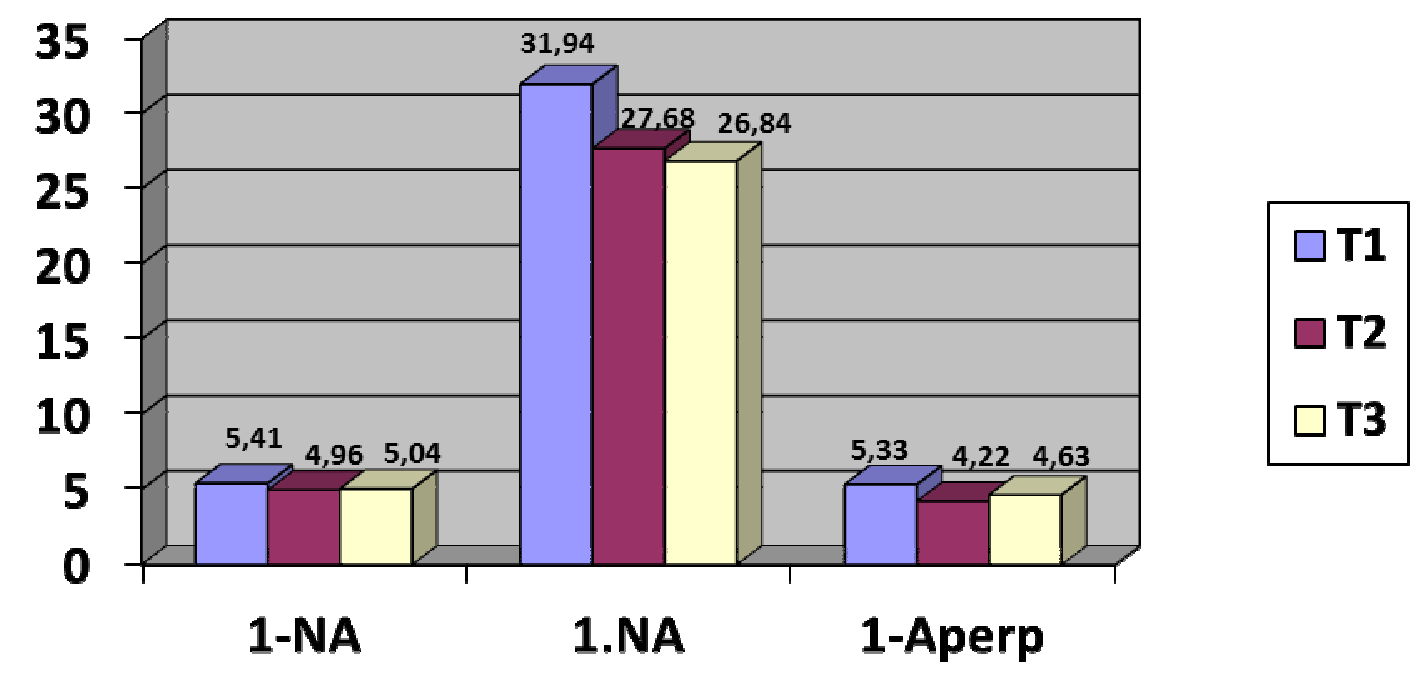

FIGURA 15: Variáveis do componente dentoalveolar superior nas fases inicial (T1), final (T2) e longo tempo pós-tratamento (T3) 
De acordo com os resultados desta investigação, outros estudos (ALMEIDA, M.R., 1998, 2003, BASS, 1983b, 1983a; BISHARA, S.E.; ZIAJA, 1989; BOLMGREN; MOSHIRI, 1986; CHANG et al., 1989; COURTNEY; HARKNESS; HERBISON, 1996; CURA et al., 1996; DRAGE; HUNT, 1990; FREITAS, B.V., 1996; HENRIQUES, 1997, JANSON, I., 1977, 1978, JANSON, M.; HASUND, 1981, MILLS, J.R., 1991, PANCHERZ, 1984, REMMER et al., 1985, THUER; INGERVALL; BURGIN, 1989, TSAMTSOURIS; VEDRENNE, 1983, VARGERVIK; HARVOLD, 1985, WIESLANDER; LAGERSTROM, 1979), também concluíram que o Bionator, atua efetivamente na correção da má oclusão de Classe II, $1^{\text {a }}$ divisão retruindo e inclinando os incisivos superiores para lingual. E, de acordo com o presente estudo, verificamos que essas alterações permanecem estáveis no período de longo tempo pós-tratamento (T2-T3).

A divergência dos resultados, em relação à intensidade da inclinação para lingual e retrusão dos incisivos superiores, observada com esta terapia (Bionator de Balter seguido do aparelho fixo) pode ser justificada pelo arco vestibular do Bionator tocar suavemente a superfície vestibular desses dentes. Uma outra justificativa encontra-se no fato dos incisivos superiores se encontrarem mais inclinados para vestibular, no início do tratamento (T1), do que protruídos. No entanto, a verticalização dos incisivos superiores pode ser altamente favorável nos casos de um trespasse horizontal acentuado com os incisivos inclinados para vestibular, características estas, frequentemente observadas na má oclusão de Classe II, $1^{\text {a }}$ divisão (BISHARA, S.E.; ZIAJA, 1989). Por outro lado, uma lingualização excessiva destes dentes pode limitar o deslocamento anterior da mandíbula.

O posicionamento dos incisivos superiores, no sentido vertical, aferido pela medida 1-PP demonstrou um pequeno, semelhante ao fisiológico, porém significativo, aumento nos períodos estudados (T1-T2 e T2-T3) (FIGURA 16). Este efeito é de extrema importância, uma vez que a extrusão excessiva desses dentes é indesejada na correção da má oclusão de Classe II, $1^{\text {a }}$ divisão. 


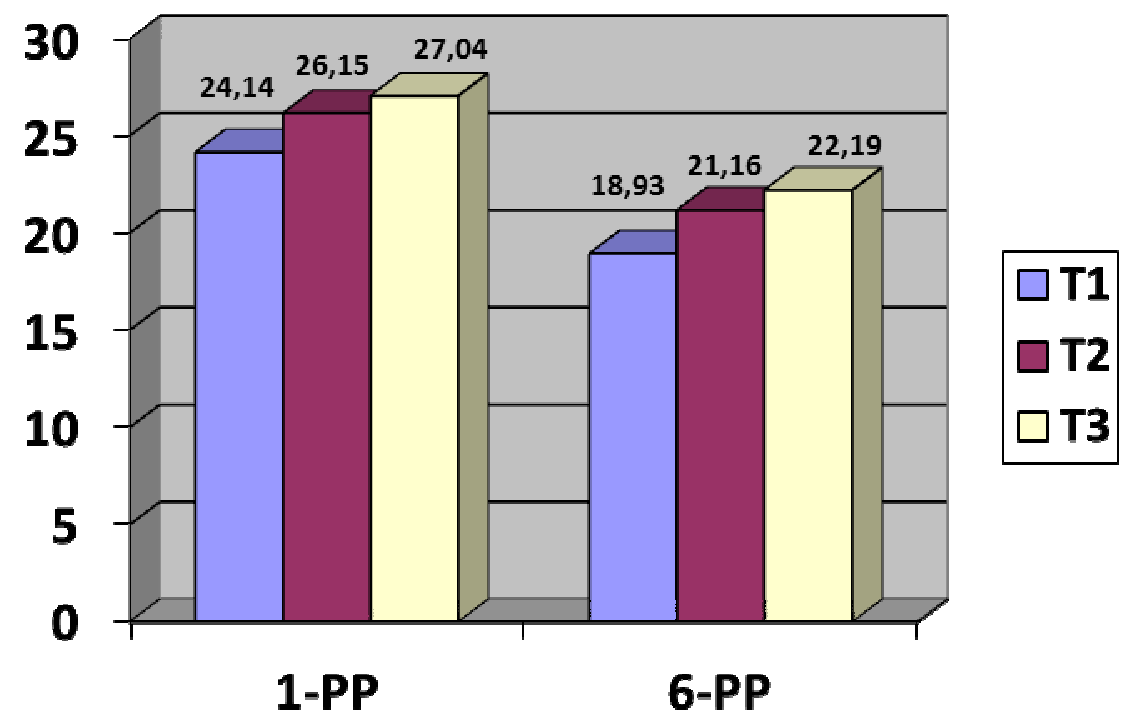

FIGURA 16: Variáveis verticais do componente dentoalveolar superior nas fases inicial (T1), final (T2) e longo tempo pós-tratamento (T3)

As posições, no sentido vertical, dos primeiros molares superiores e inferiores apresentam fundamental importância, em função da relação destes dentes com o padrão de crescimento e com a correção da Classe II. O posicionamento vertical dos molares superiores, verificado pela medida 6-PP, demonstrou um pequeno aumento, nos períodos estudados (T1-T2 e T2-T3), semelhante ao fisiológico que ocorre pelo processo de flutuação normal (FIGURA 16). Estes resultados concordam com o reportado por outros autores (HAMILTON; SINCLAIR; HAMILTON, 1987; MCNAMARA, J. A., JR.; BOOKSTEIN; SHAUGHNESSY, 1985; URSI, W.J.S, 1993), que não observaram restrição no desenvolvimento vertical dos molares superiores.

\subsubsection{Componente dentoalveolar inferior}

As medidas cefalométricas que averiguaram a posição dos incisivos $e$ primeiros molares inferiores foram: 1-NB, 1.NB, IMPA, 1-AP, 1-GoMe e 6-GoMe (FIGURAS 17 e 18). A comparação entre as variáveis iniciais e finais do tratamento (T1-T2) apresentou diferença estatisticamente significante para todas as grandezas, com exceção da medida IMPA que não diferiu. 


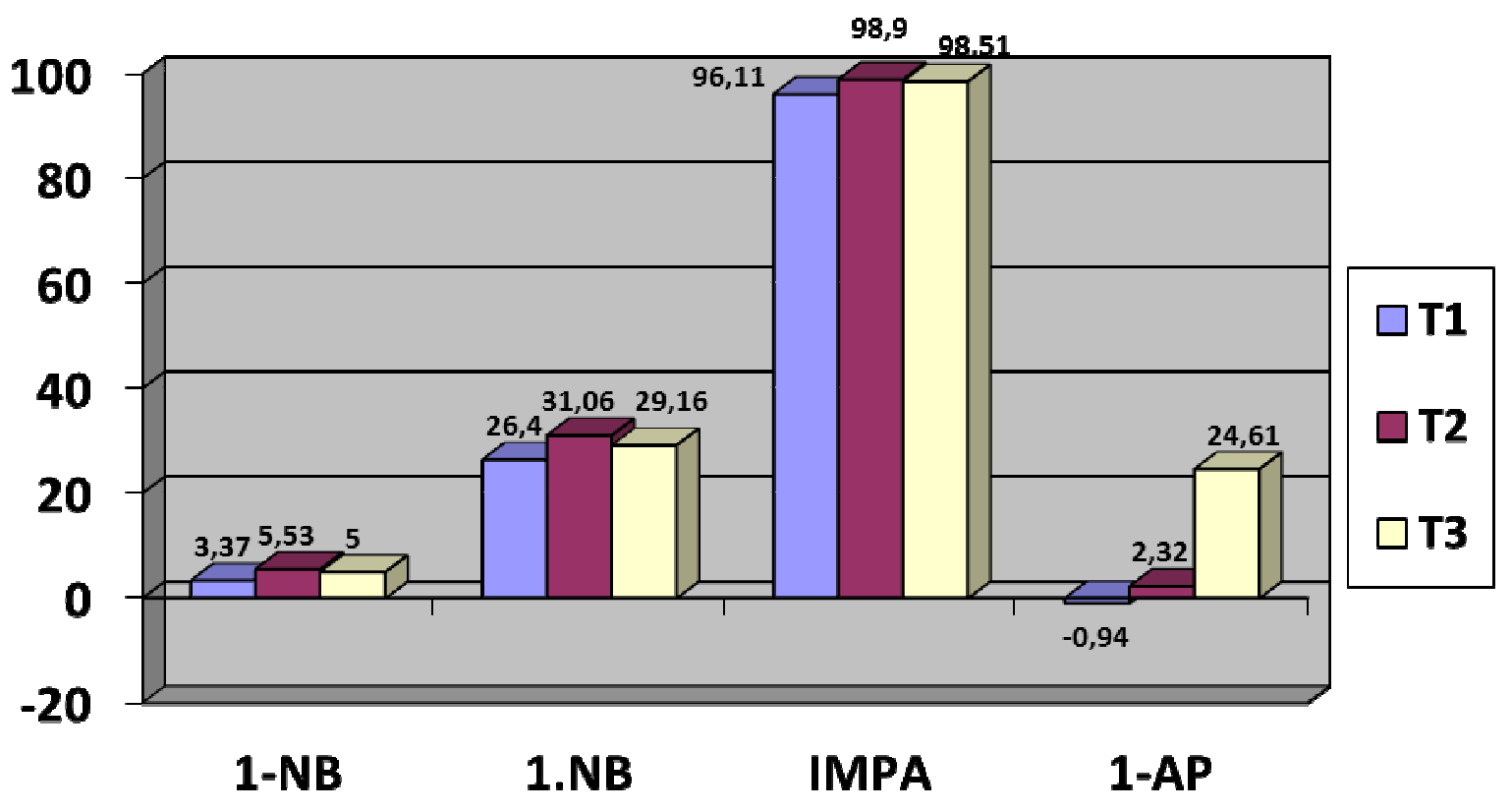

FIGURA 17: Variáveis do componente dentoalveolar inferior nas fases inicial (T1), final (T2) e longo tempo pós-tratamento (T3)

Concordando com esses resultados, outros pesquisadores (ALMEIDA, M.R., 2000a, 2003; ALMEIDA, M.R.; HENRIQUES; URSI, 2002; BISHARA, S.E.; ZIAJA, 1989; CHANG et al., 1989; DRAGE; HUNT, 1990; HENRIQUES, 1997; JANSON, I., 1977, 1978; JANSON, M.; HASUND, 1981; NELSON, C.; HARKNESS; HERBISON, 1993; PANCHERZ, 1984; THUER; INGERVALL; BURGIN, 1989; TSAMTSOURIS; VEDRENNE, 1983) verificaram uma inclinação para vestibular e maior protrusão dos incisivos inferiores em pacientes tratados com o Bionator.

Todas as alterações permaneceram estáveis no período de longo tempo póstratamento (T2-T3) (FIGURAS 17 e 18), apenas as variáveis 1-GoMe e 6-GoMe tiveram seus valores estatisticamente aumentados, provavelmente devido ao processo natural de flutuação dentária (FIGURA 18). 


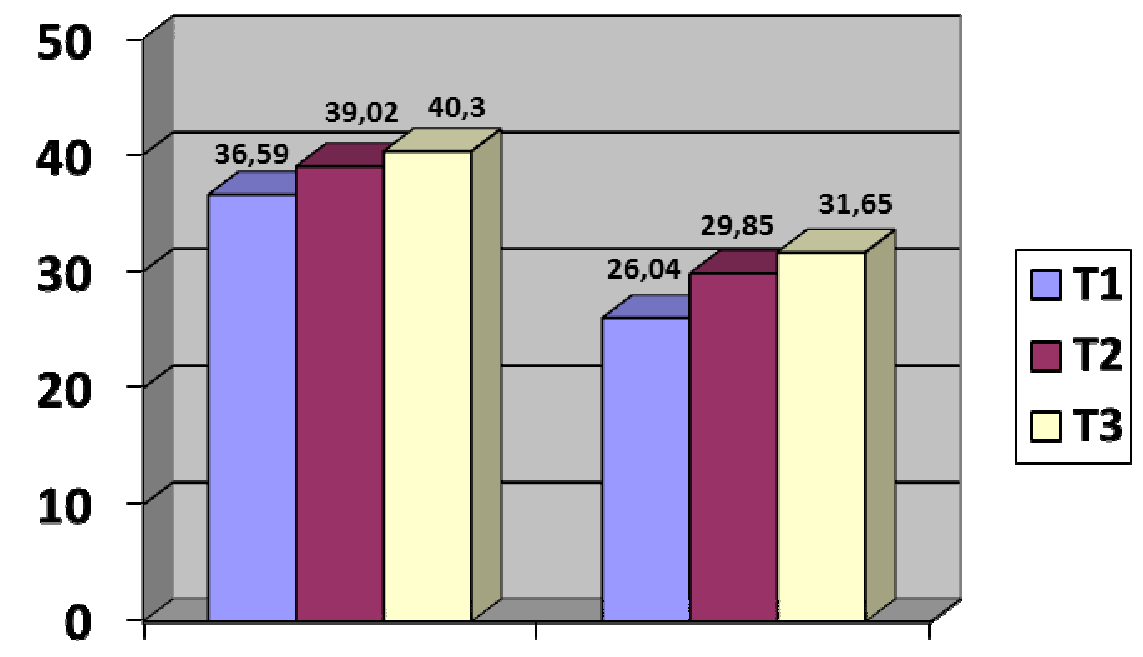

1-GoMe 6-GoMe

FIGURA 18: Variáveis verticais do componente dentoalveolar inferior nas fases inicial (T1), final (T2) e longo tempo pós-tratamento (T3)

Um fator importante que deve ser destacado é que se esperava um maior controle na inclinação dos incisivos, quando do uso do Bionator, em função do recobrimento destes dentes com resina acrílica, que tem por função evitar ou diminuir a tendência de inclinação e protrusão, bem como de restringir o desenvolvimento no sentido vertical (ALTUNA; NIEGEL, 1985; BOLMGREN; MOSHIRI, 1986; MAMANDRAS; ALLEN, 1990). Entretanto, essa restrição não foi observada no presente estudo.

Quanto ao posicionamento vertical dos primeiros molares inferiores, observou-se um aumento da medida 6-GoMe, tanto no período de tratamento (T1T2) quanto no período de longo tempo pós-tratamento (T2-T3), denotando uma extrusão desses dentes (FIGURA 18). De forma similar, outros autores (ALMEIDA, M.R., 2000a, 2000b, 2003; ALMEIDA, M.R.; HENRIQUES; URSI, 2002; BISHARA, S.E.; ZIAJA, 1989; BOLMGREN; MOSHIRI, 1986; FREITAS, B.V., 1996; HARVOLD; VARGERVIK, 1971; NELSON, C.; HARKNESS; HERBISON, 1993; TSAMTSOURIS; VEDRENNE, 1983) afirmaram que o Bionator propiciou a extrusão dos dentes posteroinferiores.

Um dos mecanismos responsáveis pela correção da má oclusão de Classe II, $1^{\mathrm{a}}$ divisão, fundamenta-se no princípio da erupção diferencial de Harvold que consiste na inibição da irrupção dos molares superiores no sentido anteroinferior e promoção da extrusão e mesialização dos dentes posteroinferiores. Esta assertiva 
refere-se a todos os aparelhos ortopédicos funcionais. Por ser o Bionator um deles, este aparelho produziu tais efeitos, principalmente no arco inferior. Portanto, os desgastes realizados no Bionator, na região dos dentes posteroinferiores, possibilitaram o restabelecimento da dimensão vertical, da sobremordida e da relação molar, porém, um maior desenvolvimento vertical dos molares inferiores pode, por sua vez, aumentar o ângulo do plano mandibular. Entretanto, essa alteração não foi observada no presente estudo.

\subsubsection{Relações dentárias}

Considera-se que a estabilidade da correção dos trespasses, horizontal e vertical, assim como da relação molar constituem fatores primordiais para se determinar o sucesso de um tratamento ortodôntico. Neste estudo, observa-se que essas variáveis foram significantemente alteradas durante o tratamento (T1-T2) e permaneceram estáveis no período de longo tempo pós-tratamento (T2-T3) (FIGURA 19). Essa correção resulta de uma somatória de alterações de natureza esquelética e dentária.

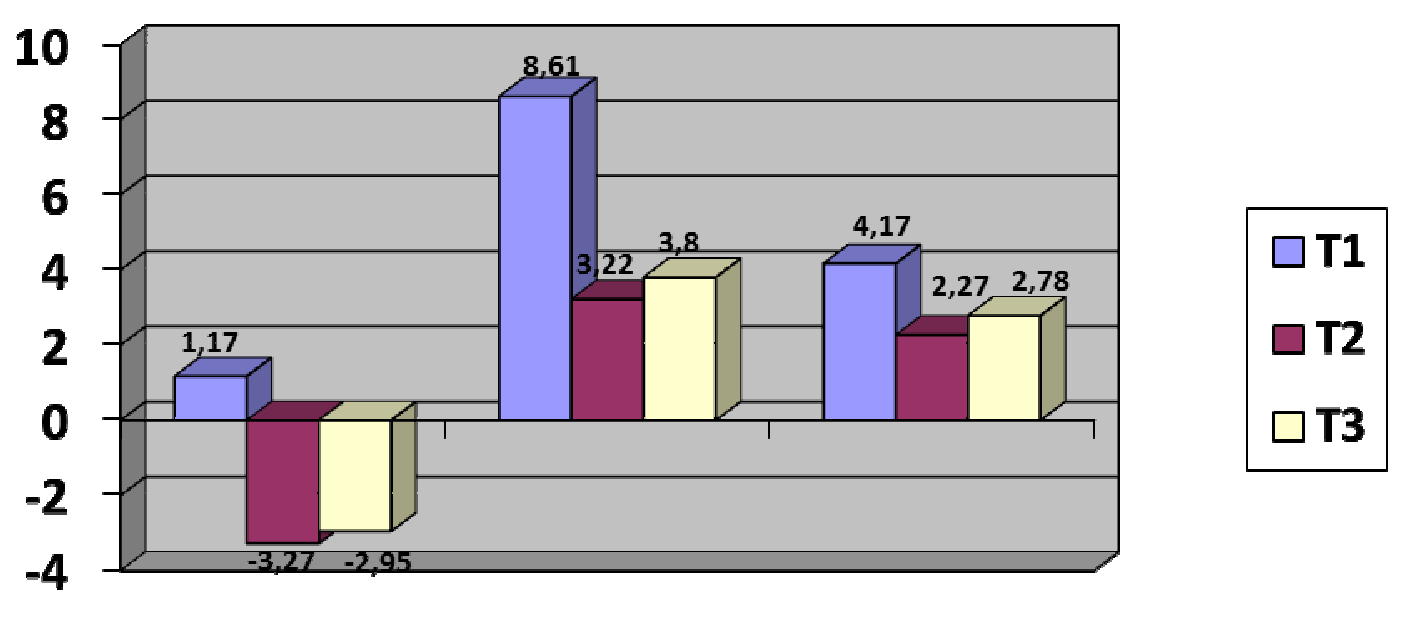

$\begin{array}{lll}\text { Rel. molar T.H. T.V. } & \text { T. }\end{array}$

FIGURA 19: Variáveis das relações dentárias nas fases inicial (T1), final (T2) e longo tempo pós-tratamento (T3)

A redução do trespasse horizontal (FIGURA 19) ocorreu em consequência da retrusão e lingualização dos incisivos superiores, vestibularização e protrusão dos incisivos inferiores em conjunto ao crescimento normal da mandíbula. Alguns autores (DRAGE; HUNT, 1990) relataram o predomínio das alterações 
dentoalveolares, na correção do trespasse horizontal por meio do Bionator, entretanto outros pesquisadores (JENA; DUGGAL; PARKASH, 2006) encontraram $57,77 \%$ de contribuição esquelética para a referida correção. Esses autores justificaram esta elevada participação das alterações esqueléticas, na redução do trespasse horizontal, em função da época em que o tratamento foi realizado, no pico de velocidade do surto de crescimento pubescente.

Assim como em alguns estudos (CHIQUETO, 2008; COPE et al., 1994; COVELL et al., 1999; KARACAY et al., 2006; KUCUKKELES; ILHAN; ORGUN, 2007; NALBANTGIL et al., 2005; RUF; PANCHERZ, 1999; STUCKI; INGERVALL, 1998), o trespasse vertical foi melhorado pela terapêutica adotada (FIGURA 19). Essa alteração segue o padrão da variável 6-GoMe, a qual justifica o comportamento do trespasse vertical nos períodos estudados (T1-T2 e T2-T3). A variável, que representa o trespasse vertical, denotou diminuição no período de tratamento (T1T2) com significância estatística (FIGURA 19). Portanto, observamos que essa variável foi corrigida com esta terapia e que permaneceu estável no período de longo tempo pós-tratamento (T2-T3) (FIGURA 19).

A correção da relação molar ocorreu, possivelmente, em consequência das alterações esqueléticas. Assim, o crescimento mandibular normal possibilitou a correção dessa relação, pois os molares acompanham o deslocamento de suas respectivas bases ósseas. Resultados semelhantes a esses, porém obtidos em decorrência do tratamento da Classe II, por meio do Ativador associado ao extrabucal, foram observados por Janson et al., em 2004. Lagerstrom et al. (1990) relataram que o crescimento mandibular normal, em direção anterior, foi importante para a correção da relação molar.

Considerando o tratamento com o Bionator, alguns autores (JENA; DUGGAL; PARKASH, 2006) revelaram que a correção da relação molar ocorre, em grande parte, devido ao crescimento diferencial da mandíbula em relação à maxila, corroborando com os resultados desta pesquisa. Os autores observaram que as alterações esqueléticas contribuíram em $73,3 \%$ na correção da relação molar com o Bionator.

Enfim, o tratamento realizado (Bionator associado ao aparelho ortodôntico fixo) foi efetivo em corrigir os trespasses, horizontal e vertical, bem como a relação molar apresentando alterações significantes e estas permaneceram estáveis no período de longo tempo pós-tratamento (FIGURA 19). 


\subsubsection{Tecidos moles}

Para verificar se 0 tratamento da Classe II, $1^{\text {a }}$ divisão com 0 aparelho ortopédico referenciado, neste estudo, associado ao aparelho fixo, contribuiu para a obtenção de um perfil tegumentar mais harmonioso, foi avaliada a seguinte grandeza cefalométrica: o ângulo nasolabial (ANL) (FIGURA 20).

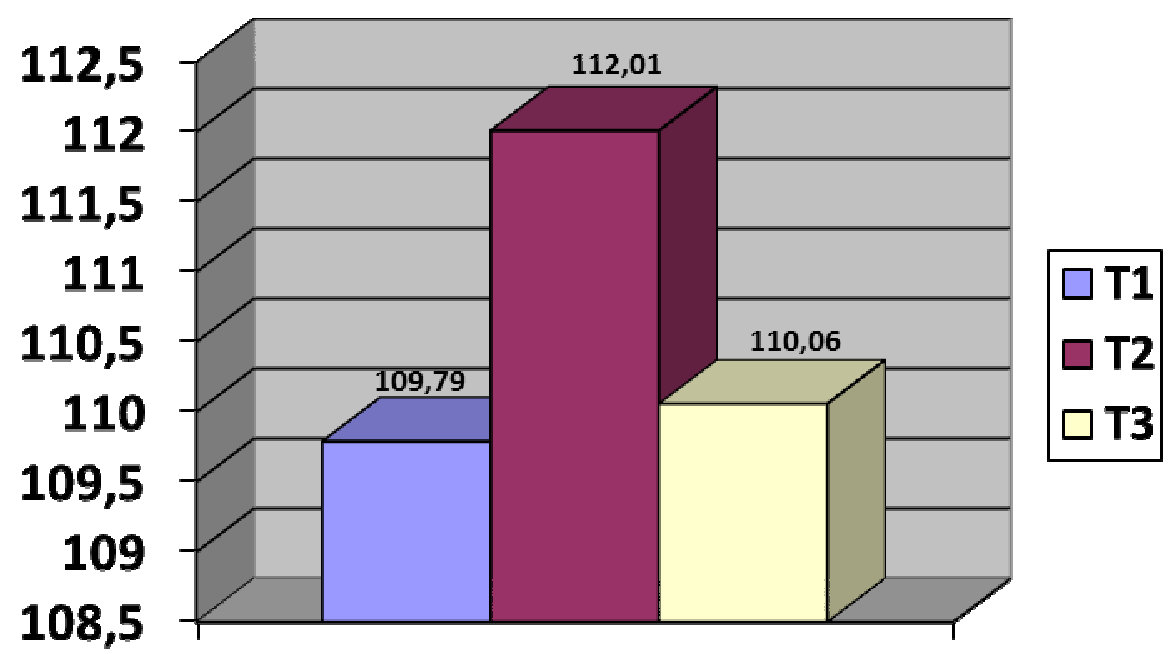

ANL

FIGURA 20: Variável dos tecidos moles nas fases inicial (T1), final (T2) e longo tempo pós-tratamento (T3)

Avaliando essa variável, não foi possível notar diferença estatisticamente significante nos períodos estudados (T1-T2 e T2-T3) (FIGURA 20). Observou-se um discreto aumento desse ângulo, no período de tratamento (T1-T2) e uma discreta diminuição desse ângulo, no período de longo tempo pós-tratamento (T2-T3), porém, ambos sem diferença estatística (FIGURA 20). Portanto, neste estudo, não houve diferença significante nos períodos analisados, mostrando que os aparelhos ortopédicos não afetam substancialmente o ângulo nasolabial, como reportado por outros autores (ALMEIDA, M.R., 2000a; LANGE et al., 1995).

\subsection{Resultados oclusais (TABELAS 6 e 7)}

Os valores do índice PAR sofreram uma redução estatisticamente significante, no período de tratamento (T1-T2), e não apresentaram diferenças, no período de longo tempo pós-tratamento (T2-T3), o que demonstra que os resultados oclusais 
obtidos foram estáveis (FIGURA 21). Poucos são os trabalhos, na literatura, que avaliaram esse tipo de terapia através do índice PAR.

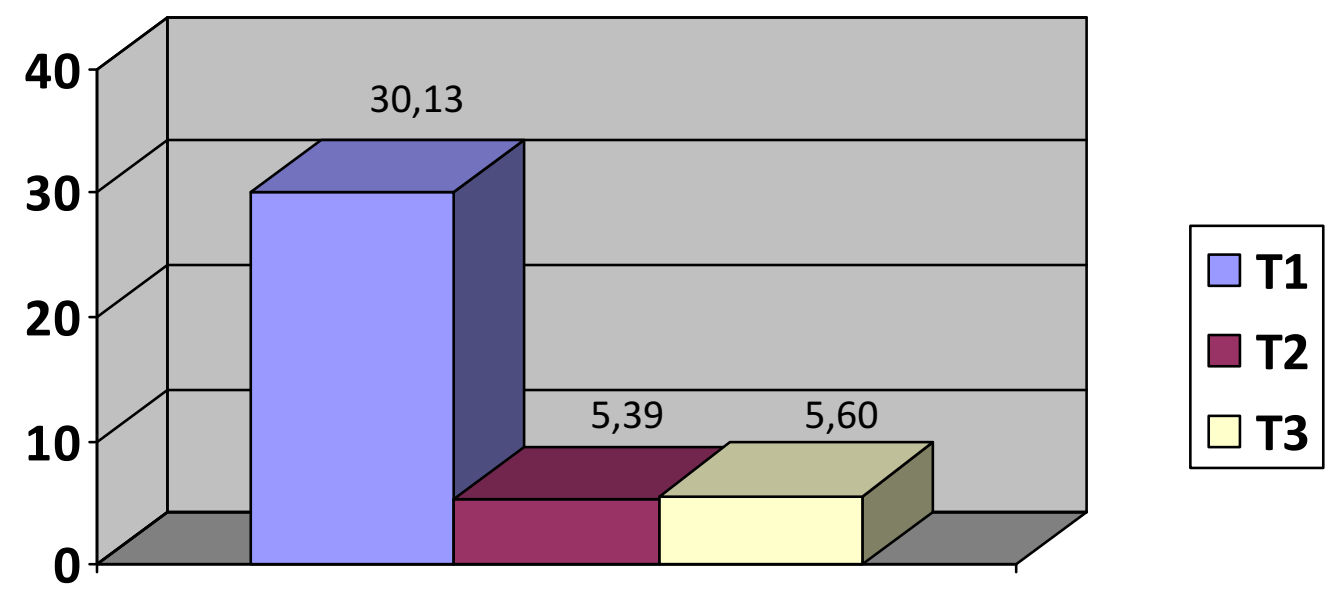

PAR

FIGURA 21: Valores do índice PAR nas fases inicial (T1), final (T2) e longo tempo pós-tratamento (T3)

Pavlow et al., em 2008, avaliaram o efeito do tratamento precoce na estabilidade da oclusão de pacientes que apresentavam má-oclusão de $\mathrm{Cl}$ II. $\mathrm{O}$ índice PAR foi usado para avaliar as mudanças na oclusão após o término do tratamento de sujeitos tratatos em 1 ou 2 fases. Para isso, modelos de estudo foram obtidos dos participantes que foram divididos em 3 grupos. Os dois primeiros foram submetidos ao tratamento precoce anteriormente à utilização do aparelho fixo convencional: grupo 1 - Bionator e grupo 2 - Splint maxilar, e o terceiro grupo não foi submetido a nenhum tratamento previamente à utilização do fixo, permanecendo, portanto, apenas em observação. O índice PAR foi calculado dos 208 pacientes que foram submetidos a essa pesquisa e 173 (83\%) pacientes foram remoldados e, novamente calculado o índice PAR num período de, aproximadamente, 5 anos após finalizado o tratamento. Como resultados obtidos, observou-se que os fatores que significantemente afetaram o índice PAR no período de longo tempo pós-tratamento foram: o índice PAR ao final do tratamento, a quantidade de anos pós-tratamento, contrariando os resultados deste trabalho, uma vez que se observou resultados estáveis, no período de longo tempo pós-tratamento (T2-T3), e o índice PAR no começo da segunda fase de tratamento. Embora o tratamento precoce, fase 1, não tenha significância estatística, os pacientes que receberam esse tipo de tratamento 
apresentaram um menor índice PAR, no início da segunda fase, quando comparados aos pacientes que não receberam esse tratamento.

Segundo as categorias do PAR final sugeridas por Richmond et al. (1992), quando o valor obtido ao final do tratamento é igual ou menor que 5 , considera-se a oclusão quase perfeita. Os pacientes terminaram o tratamento ortodôntico com resultado médio de 5,39, sugerindo oclusões próximas do ideal e, essas oclusões permaneceram estáveis (resultado médio de 5,60) no período de longo tempo póstratamento (FIGURA 21). O tratamento demonstrou também, alto padrão de melhora do índice PAR com porcentagem de $81,78 \%$. O valor está acima dos sugeridos por Richmond (1992) e Deguzman (1995), 70\% e 65\%, respectivamente. Birkeland et al., em 1997, observaram que a idade e os valores PAR, ao início e ao final do tratamento foram fatores significativos nas mudanças em longo prazo (PAVLOW et al., 2008).

A porcentagem de recidiva observada com o tratamento realizado foi de $4,90 \%$. Esse dado comprova a estabilidade que pode ser alcançada com este tipo de terapia. Concordando com esses resultados, Vigorito; Rodriguez; Hirshheimer (1998), utilizando o índice PAR, avaliaram as mudanças oclusais de pacientes em crescimento com má-oclusão de $\mathrm{Cl}$ II, $1^{\text {a }}$ divisão, durante um período de 18 meses e, como resultados, obtiveram que o grupo tratado por meio do Bionator melhorou $55,4 \%$, enquanto que o grupo controle piorou $14,7 \%$. Portanto, puderam concluir que o tratamento com Bionator, em pacientes em crescimento com má-oclusão de Cl II, $1^{\text {a }}$ divisão, modifica de forma favorável a severidade da má-oclusão.

Woods, Lee e Crawford, em 2000, realizaram uma pesquisa com modelos de estudo de 65 pacientes nos estágios: pré, pós-tratamento e pelo menos 6,5 anos após a remoção de todos os aparelhos de contenção. Não especificaram o tipo de má oclusão dos pacientes. O método de avaliação da oclusão foi o índice PAR, calculado nos modelos de cada paciente, nos três estágios avaliados. Calculou-se a média do índice PAR da amostra total e para cada subgrupo, além da porcentagem média de alteração do índice PAR entre as fases estudadas. $O$ índice PAR sofreu uma redução de $85,6 \%$ com o tratamento, semelhante à observada no presente estudo, e teve um aumento de 15,2\% no período pós-contenção. Os autores afirmaram que nem todas as alterações oclusais são negativas e, em alguns casos, é mesmo possível que ocorra uma considerável melhora oclusal durante ou após o tratamento. Concluíram que nem o índice PAR ao final do tratamento, nem a 
quantidade de alterações oclusais ocorridas durante ou após o tratamento possibilitaram a previsão da quantidade ou do tipo de alteração oclusal em longo prazo.

Otuyemi e Jones, em 1995, utilizaram o índice PAR para avaliar o tratamento e os resultados pós-contenção, em longo prazo, de 50 casos de má oclusão de Classe II, $1^{\text {a }}$ divisão. Foram empregados os modelos de estudo para registro da oclusão pré, pós-tratamento, 1 ano pós-tratamento e 10 anos pós-tratamento, estando esta última avaliação sem contenções. Os resultados sugeriram um tratamento ortodôntico de alto padrão, indicado pela porcentagem média de redução do índice PAR. Entretanto, a manutenção dos resultados pós tratamento, após 1 e 10 anos pós-contenção, apenas foi alcançada em 60 e 38\% dos casos, respectivamente. Esses resultados não conferem aos encontrados neste trabalho, uma vez que, ao calcularmos a diferença entre a melhora obtida com esta terapia e a recidiva ocorrida, encontraremos $76,88 \%$ de estabilidade no período de longo tempo pós-tratamento (T2-T3). O principal fator envolvido na deterioração foi relatado como sendo o apinhamento anteroinferior. Concluíram que, apesar de uma má oclusão de Classe II tratada com sucesso aparentemente apresentar uma tendência a deteriorar após o tratamento, muito desse resultado ocorreu devido à recidiva do apinhamento anteroinferior. No presente estudo, pelo fato da amostra utilizada fazer o uso do $3 \times 3$ inferior até a última fase analisada (longo tempo póstratamento) essa recidiva foi evitada.

\subsection{Implicações clínicas}

O tratamento da má oclusão de Classe II tem sido intensamente discutido na literatura. Diversas são as formas de correção propostas e, atualmente, existem vários aparelhos que são utilizados para esta finalidade. Torna-se, portanto, necessário conhecer as características, o modo de ação e os efeitos desses aparelhos para aplicá-los de forma mais apropriada nos diferentes casos (BARROS, 2004). É de suma importância ressaltarmos que a estabilidade é a chave fundamental para o sucesso do tratamento ortodôntico e, por esse motivo, este trabalho teve o propósito de avaliar os efeitos, limitações e adaptações dentofaciais após um período médio de dez anos de uso do aparelho Bionator de Balters, 
seguido da mecânica com aparelho fixo, no tratamento da má oclusão de Classe II, $1^{\text {a }}$ divisão.

De acordo com os resultados apresentados neste estudo, o protocolo de tratamento avaliado foi efetivo na correção da má oclusão Classe II, 1a divisão, promovendo a melhora significante na relação maxilomandibular e nas relações dentárias mantendo-se estáveis no período de longo tempo pós-tratamento (T2-T3).

Os efeitos produzidos por esta terapia foram mais evidentes nos componentes mandibular e dentário. O grau de protrusão maxilar (SNA e A-Nperp) diminuiu suavemente e sem significância. Um significante aumento da protrusão mandibular $\left(1,78^{\circ}\right)$ foi observado no período de tratamento (T1-T2) e esse aumento perdurou no período de longo tempo pós-tratamento $\left(0,53^{\circ}\right)$, mas sem significância estatística. Ressalta-se, também, que o valor médio da variação do comprimento efetivo da mandíbula foi de $8,17 \mathrm{~mm}$ no período de tratamento (T1-T2) e de 4,26 mm no período de longo tempo pós-tratamento (T2-T3), não podendo desconsiderar esta alteração clinicamente significante. Conseqüentemente às alterações nas bases ósseas, ocorreu uma melhora significativa da relação maxilomandibular e da convexidade facial. O padrão facial manteve-se estável no período de tratamento (T1-T2), o que denota que o padrão de crescimento não se alterou significantemente durante o mesmo. Entretanto, no período de longo tempo pós-tratamento (T2-T3) verificou-se uma tendência ao fechamento do ângulo do plano mandibular.

Portanto, os resultados demonstraram que a interceptação da má oclusão de Cl II, $1^{\text {a }}$ divisão por meio do Bionator de Balters, associado ao aparelho fixo, não alterou o padrão de crescimento e não aumentou demasiadamente as alturas faciais. Assim, pode-se inferir que o tratamento mencionado apresentou bons efeitos no sentido vertical, uma vez que apresentou um controle sobre o plano mandibular.

Os incisivos superiores inclinaram para lingual e retruíram no período de tratamento (T1-T2) e essa lingualização foi mantida no período de longo tempo póstratamento (T2-T3). Os inferiores vestibularizaram e protruíram na base óssea no período de tratamento (T1-T2), permanecendo estáveis no período de longo tempo pós-tratamento (T2-T3), efeitos estes que contribuem sobremaneira para a correção da Classe II. Os tecidos moles, representados pela variável ANL, não mostraram diferença estatisticamente significante nos períodos estudados (T1-T2 e T2-T3). Observou-se um discreto aumento desse ângulo no perído de tratamento (T1-T2) e, 
uma discreta diminuição desse ângulo no período de longo tempo pós-tratamento (T2-T3), porém, ambos sem diferença estatística.

Os valores do índice PAR sofreram uma redução estatisticamente significante no período de tratamento (T1-T2) e não apresentaram diferenças no período de longo tempo pós-tratamento (T2-T3), o que demonstra que os resultados oclusais obtidos foram estáveis. $O$ tratamento demonstrou também, alto padrão de melhora do índice PAR com porcentagem de $81,78 \%$ e, a porcentagem de recidiva observada com a terapia utilizada foi de $4,90 \%$. Esses dados comprovam a estabilidade que pode ser alcançada com este tipo de tratamento.

O protocolo adotado mostrou-se, portanto, eficaz na correção da má oclusão de Classe II, $1^{\underline{a}}$ divisão promovendo grandes alterações dentárias e esqueléticas e essas alterações permaneceram estáveis no período de longo tempo pós-tratamento (T2-T3) tornando essa terapia, muitas vezes, a opção de escolha para os pacientes que se encaixam nesse tipo de má-oclusão.

Diante do exposto e à luz de um estudo prospectivo, parece sensato ressaltar que toda extrapolação dos resultados desta pesquisa para a população em geral deve ser realizada com ressalvas considerando as limitações da metodologia empregada. 

7 Conclusões 



\section{CONCLUSÕES}

Com base na metodologia utilizada e nos resultados obtidos é válido concluir que:

\subsection{Componente Maxilar:}

- O tratamento estudado não propiciou alterações espaciais significantes no desenvolvimento maxilar (SNA e A-Nperp) nem no período de tratamento (T1T2), nem no período de longo tempo pós-tratamento (T2-T3). A variável Co-A aumentou no período de longo tempo pós-tratamento (T2-T3) em decorrência ao crescimento longitudinal normal da maxila. Observou-se, portanto, uma estabilidade deste componente com a terapia utilizada.

\subsection{Componente Mandibular:}

- $\quad$ O tratamento estudado promoveu um aumento na protrusão mandibular (SNB e P-Nperp) no período de tratamento (T1-T2), bem como um maior incremento no comprimento efetivo da mandíbula (Co-Gn). A protrusão mandibular permaneceu estável no período de longo tempo pós-tratamento (T2-T3) e, um aumento no comprimento efetivo da mandíbula também foi observado nesse período.

\subsection{Relação Maxilomandibular:}

- Uma melhora significante na relação maxilomandibular e na convexidade facial (ANB e Wits) foi observada durante o período de tratamento analisado (T1-T2) e, essa melhora permaneceu estável no período de longo tempo póstratamento (T2-T3). Apesar da variável Co-A/Co-Gn ter aumentando no período de tratamento (T1-T2), esse aumento foi menor do que o considerado normal e o mesmo permaneceu estável no período de longo tempo póstratamento (T2-T3). 


\subsection{Padrão facial:}

- A terapia utilizada não produziu alterações significantes no padrão de crescimento craniofacial. Verificou-se, por meio das variáveis: SN.GoGn, NSGn e FMA e, no período de longo tempo pós-tratamento (T2-T3), uma rotação do plano mandibular no sentido anti-horário. O posicionamento vertical da maxila (SN.PP) também não se alterou, permanecendo estável no período de longo tempo pós-tratamento (T2-T3). E, o aumento demasiado das alturas faciais (AFAI e S-Go) não foi observado.

\subsection{Componente dentoalveolar superior:}

- $\quad$ O tratamento estudado provocou inclinação para lingual (1.NA) e retrusão dos incisivos superiores (1-Na e 1-Aperp) que permaneceram estáveis no período de longo tempo pós-tratamento (T2-T3).

- Os primeiros molares superiores demonstraram um pequeno aumento no sentido vertical (6-PP) tanto no período de tratamento (T1-T2) quanto no período de longo tempo pós-tratamento (T2-T3), semelhante ao fisiológico, que ocorre pelo processo de flutuação normal.

\subsection{Componente dentoalveolar inferior:}

- $\quad$ O tratamento avaliado provocou uma inclinação para vestibular (1.NB e IMPA) e protrusão dos incisivos inferiores (1-NB e 1-AP) e esses valores permaneceram estáveis no período de longo tempo pós-tratamento (T2-T3).

- $\quad$ Os primeiros molares inferiores (6-GoMe) apresentaram um deslocamento no sentido vertical (extrusão) nos dois períodos estudados (T1-T2 e T2-T3) e horizontal (mesialização), contribuindo, assim para a correção da má-oclusão de CI II. 


\subsection{Relações dentárias:}

- O tratamento realizado foi efetivo em corrigir os trespasses, horizontal e vertical, bem como a relação molar apresentando alterações significantes. $\mathrm{E}$ estas permaneceram estáveis no período de longo tempo pós-tratamento (T2T3).

\subsection{Tecidos moles:}

- A variável ANL não apresentou diferença estatisticamente significante nos períodos estudados (T1-T2 e T2-T3). Observou-se um discreto aumento desse ângulo no perído de tratamento (T1-T2) e, uma discreta diminuição desse ângulo no período de longo tempo pós-tratamento (T2-T3), porém, ambos sem diferença estatística.

\subsection{Resultados oclusais:}

- Os valores do índice PAR, que demonstram os resultados oclusais, apresentaram uma redução estatisticamente significante no período de tratamento (T1-T2) e permaneceram estáveis no período de longo tempo póstratamento (T2-T3). A porcentagem de melhora obtida com esta terapia foi de $81,78 \%$ e a de recidiva foi de $4,90 \%$. 

Referências 



\section{REFERÊNCIAS}

Ahn SJ, Kim JT, Nahm DS. Cephalometric markers to consider in the treatment of Class II Division 1 malocclusion with the bionator. Am J Orthod Dentofacial Orthop. $2001 ; 119(6): 578-86$.

Al Yami EA, Kuijpers-Jagtman AM, van 't Hof MA. Stability of orthodontic treatment outcome: follow-up until 10 years postretention. Am J Orthod Dentofacial Orthop. 1999;115(3):300-4.

Almeida-Pedrin RR. Efeitos Cefalométricos do Aparelho Extrabucal Conjugado (Splint Maxilar) e do Bionator, no Tratamento da Má Oclusão de Classe II, 1a Divisão. [Tese (Doutorado)] Bauru: Universidade de São Paulo. 2003.

Almeida MR. Estudo cefalométrico comparativo, da ação de dois tipos de aparelhos ortopédicos, sobre as estruturas dentoesqueléticas e tegumentares de jovens de ambos os sexos com más oclusões de Classe II, 1a divisão de Angle. Dissertação (Mestrado) - Faculdade de Odontologia de Bauru, Universidade de São Paulo. 1997.

Almeida MR. Estudo cefalométrico comparativo, da ação de dois tipos de aparelhos ortopédicos, sobre as estruturas dentoesqueléticas e tegumentares de jovens de ambos os sexos com más oclusões de Classe II, 1a divisão. Ortodontia. $1998 ; 31(2): 32-52$.

Almeida MR. Avaliação Cefalométrica Comparativa da Interceptação da Má Oclusão de Classe II, 1ํㅡㅁ Divisão, Utilizando o Aparelho de Frankel e Bionator de Balters. [Tese (Doutorado)] Bauru: Universidade de São Paulo. 2000a.

Almeida MR. Efeitos do Bionator de Balters sobre o complexo dentoesqueléticofacial comparado a uma amostra não tratada de classe II. J Bras Ortodon Ortop Facial. 2000b;5(30):38-48.

Almeida MR. Treatment effects produced by the Bionator appliance. Comparision with an untreated Class II sample. Europ J Orthodont. 2003.

Almeida MR. Treatment effects produced by the Bionator appliance. Comparison with an untreated Class II sample. Eur J Orthod. 2004;26(1):65-72. 
Almeida MR, Henriques JFC, Ursi W. Comparative study of the Fränkel (FR-2) and bionator appliances in the treatment of Class II malocclusion. Am J Orthod Dentofacial Orthop. 2002;121(5):458-66.

Almeida MRD. Avaliação cefalométrica comparativa da interceptação da má oclusão de classe II, $1^{\text {a }}$ divisão utilizando os aparelhos de Fränkel e Bionator de Balters. Rev Dent Press Ortodon Ortoped Facial. 2001;6(6):11-27.

Altemus LA. Horizontal and vertical dentofacial relationships in normal and Class II, division 1 malocclusion in girls 11-15 years. Angle Orthodont. 1955;25(3):120-37.

Altuna G, Niegel S. Bionators in Class II treatment. J Clin Orthod. 1985;19(3):185-91.

Anderson DL, Popovich F. Lower cranial height vs craniofacial dimensions in Angle Class II malocclusion. Angle Orthod. 1983;53(3):253-60.

Anderson GM. On the diagnosis and treatment of "distocclusion". Am J Orthod Oral Surg. 1946;32(2):88-94.

Angle EH. Classification of malocclusion. Dent Cosmos. 1899; 41:248-64.

Angle EH. Malocclusion of the teeth. $7^{\text {th }}$ ed. Philadelphia, SSWhite. 1907.

Araújo AM, Buschang PH, Melo ACM. Adaptive condylar growth and mandibular remodelling changes with bionator therapy-an implant study. Eur J Orthod. 2004;26(5):515-22.

Araújo E, Souki M. Bolton anterior tooth size discrepancies among different malocclusion groups. Angle Orthod. 2003;73(3):307-13.

Artun J, Garol JD, Little RM. Long-term stability of mandibular incisors following successful treatment of Class II, Division 1, malocclusions. Angle Orthod. 1996;66(3):229-38.

Arya BS, Savara BS, Thomas DR. Prediction of first molar occlusion. Am J Orthod. 1973;63(6):610-21.

Ascher F. The bionator. In: Graber, T.M.; Neumann, B. Removable orthodontic appliances. Philadelphia, Saunders. 1977:229-46. 
Baccetti T, Franchi L, McNamara JA, Jr., Tollaro I. Early dentofacial features of Class II malocclusion: a longitudinal study from the deciduous through the mixed dentition. Am J Orthod Dentofacial Orthop. 1997;111(5):502-9.

Balters W. Guia de la técnica del Bionator. Buenos Aires, Círculo Argentino de Odontologia. 1969.

Baltromejus S, Ruf S, Pancherz H. Effective temporomandibular joint growth and chin position changes: Activator versus Herbst treatment. A cephalometric roentgenographic study. Eur J Orthod. 2002;24(6):627-37.

Barros SEC. Avaliação do grau de eficiência do tratamento da Classe II realizado sem extrações e com extrações de dois pré-molares superiores. Bauru: Universidade de São Paulo / Faculdade de Odontologia de Bauru. 2004.

Bass NM. Dento-facial orthopaedics in the correction of Class II malocclusion. Brit J Orthodont. 1982;9(1):p.3-31.

Bass NM. Orthopedic coordination of dentofacial development in skeletal Class II malocclusion in conjunction with edgewise therapy. Part II. Am J Orthod. 1983a;84(6):466-90.

Bass NM. Orthopedic coordination of dentofacial development in skeletal Class II malocclusion in conjunction with edgewise therapy (Part I). Am J Orthod. 1983b;84(5):361-83.

Baumrind S, Frantz RC. The reliability of head film measurements. Amer J Orthodont. 1971;60(2):111-27.

Bertoz FA, Santos ECA, Mendonça MR, Cuoghi OA, Reis PMP, Torres ICP. Características cefalométricas de pacientes com má oclusão de Classe II. Rev APEO. 2003;1(1):35-41.

Bigliazzi R, Kessner CA, Faltin Junior K. Estudos das alterações anatômicas e morfológicas em pacientes Classe II, divisão 1aㅡ, com retrognatismo mandibular tratados com o bionator de Balters, empregando-se a análise das contrapartes de enlow. Rev Dent Press Ortodon Ortopedi Facial. 2000;5(2):9-19. 
Birkeland K, Furevik J, Boe OE, Wisth PJ. Evaluation of treatment and post-treatment changes by the PAR Index. Eur J Orthod. 1997;19(3):279-88.

Bishara SE. Mandibular changes in persons with untreated and treated Class II division 1 malocclusion. Am J Orthod Dentofacial Orthop. 1998;113(6):661-73.

Bishara SE, Bayati P, Jakobsen JR. Longitudinal comparisons of dental arch changes in normal and untreated Class II, Division 1 subjects and their clinical implications. Am J Orthod Dentofacial Orthop. 1996;110(5):483-9.

Bishara SE, Cummins DM, Jorgensen GJ, Jakobsen JR. A computer assisted photogrammetric analysis of soft tissue changes after orthodontic treatment. Part I: Methodology and reliability. Am J Orthod Dentofacial Orthop. 1995;107(6):633-9.

Bishara SE, Hoppens BJ, Jakobsen JR, Kohout FJ. Changes in the molar relationship between the deciduous and permanent dentitions: a longitudinal study. Am J Orthod Dentofacial Orthop. 1988;93(1):19-28.

Bishara SE, Jakobsen JR, Vorhies B, Bayati P. Changes in dentofacial structures in untreated Class II division 1 and normal subjects: a longitudinal study. Angle Orthod. 1997;67(1):55-66.

Bishara SE, Ziaja RR. Functional appliances: a review. Am J Orthod Dentofacial Orthop. 1989;95(3): 250-8.

Bolmgren GA, Moshiri F. Bionator treatment in Class II, division 1. Angle Orthod. 1986;56(3):255-62.

Bondemark L, Holm AK, Hansen K, Axelsson S, Mohlin B, Brattstrom V. Longterm stability of orthodontic treatment and patient satisfaction. A systematic review. Angle Orthod. 2007;77(1):181-91.

Brandão AMB, G.C. D-R, L. CF. Avaliação comparativa entre as características da má oclusão classe II divisao $1^{\underline{a}}$ obtidas pela cefalometria e análise facial subjetiva. Revista Dental Press de Ortodontia e Ortopedia Maxilar. 2001;6(2):33-40.

Brangeli LAM. Avaliação comparativa da influência do tratamento com ortopedia nas estruturas faciais esqueléticas e tegumentares, de jovens Classe II, 1a Divisão de Angle [Tese (Doutorado)] Bauru: Universidade de São Paulo. 2000. 
Broadbent BH. A new X-ray technique and its application to orthodontia. Angle Orthodont. 1931;1(2):45-56.

Broadbent BH. The face of the normal child. Angle Orthodont. 1937;7(4):183-208.

Brodie AG. On the growth pattern of the human head. From the third month to the eighth year of life. Amer J Anat. 1941;68(1):209-62.

Brodie AG. Facial patterns. A theme on variation. Angle Orthodont. 1946;16(3-4):7587.

Buschang PH, Tanguay R, Demirjian A, LaPalme L, Turkewicz J. Mathematical models of longitudinal mandibular growth for children with normal and untreated Class II, division 1 malocclusion. Eur J Orthod. 1988;10(3):227-34.

Cançado RH. Estudo comparativo dos resultados oclusais e da eficiência dos protocolos de tratamento em uma e duas fases da má oclusão Classe II, Divisão 1. [Tese (Doutorado)] Bauru: Faculdade de Odontologia de Bauru - Universidade de São Paulo. 2005.

Cançado $\mathrm{RH}$. Occlusal outcomes and efficiency of 1- and 2-phase protocols in Class II, division 1 malocclusion treatment. Am J Orthod Dentofacial Orthop. 2006.

Cangialosi TJ, Meistrell ME, Jr., Leung MA, Ko JY. A cephalometric appraisal of edgewise Class II nonextraction treatment with extraoral force. Am J Orthod Dentofacial Orthop. 1988;93(4):315-24.

Carels C, Reychler A, Van Der Linden FP. Cephalometric evaluation of dentoskeletal changes during treatment with the Bionator type 1. J Oral Rehabil. 1997;24(11):841-8.

Carter NE. Dentofacial changes in untreated Class II Division 1 subjects. Brit $\mathrm{J}$ Orthod. 1987;14(4):225-34.

Chang HF, Wu KM, Chen KC, Cheng MC. Effects of activator treatment on Class II, division 1 malocclusion. J Clin Orthod. 1989;23(8):560-3. 
Chiqueto KFG. Comparação das alterações cefalométricas produzidas pelo aparelho MARA e Bionator no tratamento da Classe II, 1a divisão. [Tese (Doutorado)] Bauru: Faculdade de Odontologia de Bauru - Universidade de São Paulo. 2008.

Clements KM, Bollen AM, Huang G, King G, Hujoel P. Activation time and material stiffness of sequential removable orthodontic appliances. Part 2: Dental improvements. Am J Orthod Dentofacial Orthop. 2003;124(5):502-8.

Cope JB, Buschang PH, Cope DD, Parker J, Blackwood HO, 3rd. Quantitative evaluation of craniofacial changes with Jasper Jumper therapy. Angle Orthod. 1994;64(2):113-22.

Courtney M, Harkness M, Herbison P. Maxillary and cranial base changes during treatment with functional appliances. Am J Orthod Dentofacial Orthop.

1996;109(6):616-24.

Covell DA, Jr., Trammell DW, Boero RP, West R. A cephalometric study of class II Division 1 malocclusions treated with the Jasper Jumper appliance. Angle Orthod. 1999;69(4):311-20.

Craig CE. The skeletal patterns characteristic of class I and class II, division I malocclusions in norma lateralis. Angle Ortodont. 1951;21(1):44-56.

Creekmore TD, Radney LJ. Frankel appliance therapy: orthopedic or orthodontic? Am J Orthod. 1983;83(2):89-108.

Cruz KS. Efeitos dos aparelhos funcionais na correção da má oclusão de classe II. Rev Dent Press Ortodon Ortopedi Facial. 2000;5(4):43-52.

Cura N, Sarac M, Ozturk Y, Surmeli N. Orthodontic and orthopedic effects of Activator, Activator-HG combination, and Bass appliances: a comparative study. Am J Orthod Dentofacial Orthop. 1996;110(1):36-45.

de Almeida MR, Henriques JF, Ursi W. Comparative study of the Frankel (FR-2) and bionator appliances in the treatment of Class II malocclusion. Am J Orthod Dentofacial Orthop. 2002;121(5):458-66.

De Castro N. The challenge of Class II, division 1 malocclusion. Amer J Orthodont. 1960;46(11):829-33. 
DeGuzman L, Bahiraei D, Vig KW, Vig PS, Weyant RJ, O'Brien K. The validation of the Peer Assessment Rating index for malocclusion severity and treatment difficulty. Am J Orthod Dentofacial Orthop. 1995;107(2):172-6.

Dermaut LR, van den Eynde F, de Pauw G. Skeletal and dento-alveolar changes as a result of headgear activator therapy related to different vertical growth patterns. Eur J Orthod. 1992;14(2):140-6.

Derringer K. A cephalometric study to compare the effects of cervical traction and Andresen therapy in the treatment of class II division 1 malocclusion. Part 2-Dentoalveolar changes. Br J Orthod. 1990;17(2):89-99.

DeVincenzo JP. Changes in mandibular length before, during, and after successful orthopedic correction of Class II malocclusions, using a functional appliance. Am J Orthod Dentofacial Orthop. 1991;99(3):241-57.

Devreese H, De Pauw G, Van Maele G, Kuijpers-Jagtman AM, Dermaut L. Stability of upper incisor inclination changes in Class II division 2 patients. Eur J Orthod. $2007 ; 29(3): 314-20$.

Drage KJ, Hunt NP. Overjet relapse following functional appliance therapy. Br J Orthod. 1990;17(3):205-13.

Drelich RC. A cephalometric study of untreated class II, division 1 malocclusion. Angle Orthodont. 1948;18(3-4):70-5.

Eirew HL. The Bionator. Brit J Orthod. 1981;8(1):33-6.

El-Mangoury $\mathrm{NH}$. Orthodontic relapse in subjects with varying degrees of anteroposterior and vertical dysplasia. Am J Orthod. 1979;75(5):548-61.

Elms TN, Buschang PH, Alexander RG. Long-term stability of Class II, Division 1, nonextraction cervical face-bow therapy: II. Cephalometric analysis. Am J Orthod Dentofacial Orthop. 1996b;109(4):386-92.

Faltin CO, Faltin Junior K. Bionator de Balters. Rev Dent Press Ortodon Ortopedi Facial. 1998;3(6):70-95. 
Faltin KJ, Faltin RM, Baccetti T, Franchi L, Ghiozzi B, McNamara JA, Jr. Long-term effectiveness and treatment timing for Bionator therapy. Angle Orthod.

2003;73(3):221-30.

Fischer B. Treatment of Class II, division 1 (Angle). Variation and the "individuality hypothesis". Angle Orthodont. 1950;20(2):116-34.

Fisk GV, Culbert RM, Branger RM, Hemrrend B, Moyers RE. The morphology and physiology of distocclusion. Am J Orthod. 1953;39:3-12.

Freitas BV. Estudo das alterações esqueléticas e dentárias em pacientes do sexo feminino com má-oclusão de Classe II, divisão 1, com retrognatismo mandibular, tratados por meio do Bionator de Balters, no período pré-puberal. Dissertação (Mestrado) - Faculdade de Ciências Biológicas e da Saúde do Instituto Metodista de Ensino Superior, da Federação de Escolas Speriores do ABC São Bernardo do Campo. 1996.

Freitas BV, Vigorito JW. Estudo das alterações esqueléticas e dentárias em pacientes do sexo feminino com má-oclusão de Classe II, div. $1 \mathrm{com}$ retrognatismo mandibular, tratados por meio do bionator de Balters, no periodo pré-puberal. Ortodontia. 1999;32(1):29-43.

Freitas MR, Freitas DS, Pinheiro FHSL, Freitas KMS. Prevalência das más oclusões em pacientes inscritos para tratamento ortodôntico na Faculdade de Odontologia de Bauru-USP. Rev Fac Odontol Bauru. 2002;10(3):164-9.

Freunthaller P. Cephalometric observation in Class II, Division I malocclusions treated with the activator. Angle Orthod. 1967;37(1):18-25.

Ghafari J, King GJ, Tulloch JF. Early treatment of Class II, division 1 malocclusion comparison of alternative treatment modalities. Clin Orthod Res. 1998;1(2):107-17.

Gianelly AA, Arena SA, Bernstein L. A comparison of Class II treatment changes noted with the light wire, edgewise, and Frankel appliances. Am J Orthod. 1984;86(4):269-76.

Gilmore WA. Morphology of the adult mandible in Class II, division 1 malocclusion and in excellent oclusion. Angle Orthodont. 1950;20(3):137-46. 
Glenn G, Sinclair PM, Alexander RG. Nonextraction orthodontic therapy: posttreatment dental and skeletal stability. Am J Orthod Dentofacial Orthop. $1987 ; 92(4): 321-8$.

Gottlieb EL. Relapse. J Clin Orthod. 1971;5(8):417-8.

Graber TM, Neumann B. Removable orthodontic appliances. 2nd ed Philadelphia, Saunders. 1984.

Graber TM, Neumann B. Aparelhos ortodônticos removíveis. 2ed São Paulo, Panameicana. 1987.

Graber TM, Rakosi T, Petrovic AG. Dentofacial orthopedics with functional appliances. 2nd ed St Louis, Mosby. 1997.

Graber TM, Rakosi T, Petrovic AG. Ortopedia dentofacial com aparelhos funcionais. 2 ed Rio de Janeiro, Guanabara Koogan. 1999.

Gurgel JA, Almeida RR, Pinzan A. Avaliação comparativa das alterações esqueléticas maxilomandibulares entre jovens, do sexo masculino, tratados ortodonticamente da má oclusão de Classe II, $1^{\text {a }}$ divisão e com oclusão normal. Rev Dent Press Ortodon Ortoped Facial. 2001;6(1):39-50.

Hamilton SD, Sinclair PM, Hamilton $\mathrm{RH}$. A cephalometric, tomographic, and dental cast evaluation of Frankel therapy. Am J Orthod Dentofacial Orthop. 1987;92(5):42736.

Han UK, Vig KW, Weintraub JA, Vig PS, Kowalski CJ. Consistency of orthodontic treatment decisions relative to diagnostic records. Am J Orthod Dentofacial Orthop. $1991 ; 100(3): 212-9$.

Haralabakis NB, Halazonetis DJ, Sifakakis IB. Activator versus cervical headgear: superimpositional cephalometric comparison. Am J Orthod Dentofacial Orthop. 2003;123(3):296-305.

Harris EF, Behrents RG. The intrinsic stability of Class I molar relationship: a longitudinal study of untreated cases. Am J Orthod Dentofacial Orthop. 1988;94(1):63-7. 
Harvold EP, Vargervik KS. Morphogenetic response to activator treatment. Am J Orthod. 1971;60(5):478-90.

Hashim HA. Analysis of activator treatment changes. Aust Orthod J. 1991;12(2):1004.

Helm S, Kreiborg S, Solow B. Psychosocial implications of malocclusion: a 15-year follow-up study in 30-year-old Danes. Am J Orthod. 1985;87(2):110-8.

Henriques JFC. Tratamento ortopédico ortodôntico: considerações gerais e relato de um caso clínico. Ortodontia. 1991;24(3):25-31.

Henriques JFC. Tratamento da má oclusão de classe II, $1^{\text {a }}$ divisão, com retrusão mandibular, utilizando o bionator previamente à aparelhagem fixa: relato de um caso clínico. Ortodontia. 1997;30(3):74-81.

Henriques JFC. Avaliação da influência do tratamento com bionator nas estruturas faciais tegumentares de jovens com Classe II 1르 Divisão de Angle. Ortodontia. $2001 ; 34(3): 57-64$.

Henriques JFC, Maltagliati LA, Pinzan A, Freitas MR. Estudo longitudinal das características da má-oclusão de classe II, 1a divisão sem tratamento, em jovens brasileiros, leucodermas, por um período médio de 3 anos e 4 meses. Rev Dental Press Ortodon Ortop Maxilar. 1998;3(3):52-66.

Henry RG. A classification of Class II, division 1 malocclusion. Angle Orthodont. $1957 ; 27(2): 83-92$.

Hirzel H, Grewe J. Activators: a practical approach. Am J Orthod. 1974;66(5):557-70.

Houston WJ. The analysis of errors in orthodontic measurements. Am J Orthod. 1983;83(5):382-90.

Hug HU. Periodontal status and its relationship to variations in tooth position. An analysis of the findings reported in the literature. Helv Odont Acta. 1982;26:11-24.

Illing HM, Morris DO, Lee RT. A prospective evaluation of Bass, Bionator and Twin Block appliances. Part I--The hard tissues. Eur J Orthod. 1998;20(5):501-16. 
Jacobson A. The Wits appraisal of jaw disharmony. Amer J Orthodont. 1975;67(2):125-38.

Jakobsson SO, Paulin G. The influence of activator treatment on skeletal growth in Angle Class II: 1 cases. A roentgenocephalometric study. Eur J Orthod. 1990;12(2):174-84.

Janson G, Caffer D de C, Henriques JF, de Freitas MR, Neves LS. Stability of Class II, division 1 treatment with the headgear-activator combination followed by the edgewise appliance. Angle Orthod. 2004;74(5):594-604.

Janson GRP, Caffer DC, Martins DR, Henriques JFC, Freitas MR, Pinzan AO. O Centro de Estudo de Crescimento da Faculdade de Odontologia de Bauru, Universidade de São Paulo. R Dental Press Ortodon Ortop Facial. 2001;6(4):67-75.

Janson I. A cephalometric study of the efficiency of the bionator. Trans Europ Orthod Soc. 1977;28:283-98.

Janson I. Skelettale und dentoalveoläre veränderungen durch die bionatorbehandlung in der vorpubetären und pubertären wachstumszeit. Fortschr Kieferorthop. 1978;39(1):62-76.

Janson IR, Noachtar R. Functional appliance therapy with the Bionator. Sem Orthod. 1998;4(1):33-45.

Janson $M$, Hasund A. Functional problems in orthodontic patients out of retention. Eur J Orthod. 1981;3(3):173-9.

Janson $M$, Hasund $A$. Functional problems in orthodontic patients out of retention. Europ J Orthodont. 1983;3:73-9.

Jena AK, Duggal R, Parkash H. Skeletal and dentoalveolar effects of Twin-block and bionator appliances in the treatment of Class II malocclusion: a comparative study. Am J Orthod Dentofacial Orthop. 2006;130(5):594-602.

Karacay S, Akin E, Olmez H, Gurton AU, Sagdic D. Forsus Nitinol Flat Spring and Jasper Jumper corrections of Class II division 1 malocclusions. Angle Orthod. 2006;76(4):666-72. 
Karlsen AT. Craniofacial morphology in children with Angle Class II-1 malocclusion with and without deepbite. Angle Orthodont. 1994;64(6):437-46.

Karlsen AT, Krogstad O. Morphology and growth in convex profile facial patterns: a longitudinal study. Angle Orthod. 1999;69(4):334-44.

Kean MR. Some aspects of facial depth in Class II, division 1 malocclusion. Angle Orthodont. 1958;28(1):1-11.

Keeling SD. Anteroposterior skeletal and dental changes after early Class II treatment with bionators and headgear. Am J Orthod Dentofacial Orthop. 1998;113(1):40-50.

Kerr WJ, Hirst D. Craniofacial characteristics of subjects with normal and postnormal occlusions--a longitudinal study. Am J Orthod Dentofacial Orthop. 1987;92(3):207-12.

Kilpelainen PV, Phillips C, Tulloch JF. Anterior tooth position and motivation for early treatment. Angle Orthod. 1993;63(3):171-4.

King TB. A cephalometric study of the positional relationship of the incisors and apical bases to each other in Class I and Class II, division 1. Amer J Orthodont. 1962;48(8):629-30.

Klocke A, Nanda RS, Kahl-Nieke B. Skeletal Class II patterns in the primary dentition. Am J Orthod Dentofacial Orthop. 2002;121(6):596-601.

Krogman WM, Sassouni V. Syllabus in Roentgenographic Cephalometry. Philadelphia, College Offset. 1957.

Kucukkeles N, Ilhan I, Orgun IA. Treatment efficiency in skeletal Class II patients treated with the jasper jumper. Angle Orthod. 2007;77(3):449-56.

Lagerstrom LO. Dental and skeletal contributions to occlusal correction in patients treated with the high-pull headgear-activator combination. Amer J Orthodont Dentofac Orthop. 1990;97(6):495-504. profile following treatment with the bionator. Angle Orthod. 1995;65(6):423-30. 
Legan HL, Burstone CJ. Soft tissue cephalometric analysis for orthognatic surgery. J oral Surg. 1980;38(10):744-51.

Lehman R, Romuli A, Bakker V. Five-year treatment results with a headgear-activator combination. Eur J Orthod. 1988;10(4):309-18.

Lieberman MA, Gazit E. Guides to orthodontic treatment timing. J Am Dent Assoc. 1974;88(3):555-62.

Linder-Aronson S, Woodside DG, Daigle DJ. A longitudinal study of the growth in lenght of the maxila in boys between ages 6-20 years. Trans Europ Orthod Soc. 1975;51:169-79.

Linklater RA, Fox NA. The long-term benefits of orthodontic treatment. Br Dent J. 2002;192(10):583-7.

Lo FD, Hunter WS. Changes in nasolabial angle related to maxillary incisor retraction. Am J Orthod. 1982;82(5):384-91.

Luedtke GL. Preventive orthodontics: early reduction of Class II, Division 1 malocclusion. Am J Orthod. 1973;63(1):18-29.

Maia A. Estudo cefalométrico das características da má oclusão de Classe II/1, em brasileiros da região nordeste, em fase de dentadura mista. Ortodontia. 1998;31(2):53-68.

Maj G, Luzi C, Lucchese P. A cephalometric appraisal of Class II and Class III malocclusions. Angle Orthodont. 1960;30(1):26-34.

Maltagliati LA. Influence of orthopedic treatment on hard and soft facial structures of individuals presenting with Class II, division 1 malocclusion. A comparative study. J Appl Oral Sci. 2004;12(2):164-70.

Mamandras AH, Allen LP. Mandibular response to orthodontic treatment with the Bionator appliance. Am J Orthod Dentofacial Orthop. 1990;97(2):113-20. 
Marcondes AR. Integration of certain variants as a determinant of facial morphology. Thesis (Master of Science) - University of Illinois, 1955. apud WALLIS, S.F169. Integration of certain variants of the facial skeleton in Class II, division 2 malocclusion. Angle Orthodont. 1963;33(1):60-7.

Martin RA. An analysis of normal cases and Class II, division 1 cases by cephalometric evaluation. Amer J Orthodont. 1958;44(2):147.

Martins DR. Atlas de desenvolvimento craniofacial. Atlas de desenvolvimento craniofacial Santos, São Paulo. 1998.

Martins JCR. Avaliação cefalométrica comparativa dos resultados da interceptação da má oclusão de CI II, divisão 1 de Angle, efetuados com o aparelho extrabucal ou com o bionator. Tese (Livre-docência) - Faculdade de Odontologia de Araraquara Universidade Estadual Paulista. 1997:333p.

Martins LP. Tratamento da Classe II, divisão 1, com o aparelho Bionator de Balters: relato de caso clínico. J Bras Ortodon Ortop Facial. 2001;6(31):59-63.

McNamara JA, Jr. Components of class II malocclusion in children 8-10 years of age. Angle Orthod. 1981;51(3):177-202.

McNamara JA, Jr. A method of cephalometric evaluation. AmJ Orthodont. 1984;86(6):449-69.

McNamara JA, Jr., Bookstein FL, Shaughnessy TG. Skeletal and dental changes following functional regulator therapy on class II patients. Am J Orthod.

1985;88(2):91-110.

McNamara JA, Jr., Howe RP, Dischinger TG. A comparison of the Herbst and Frankel appliances in the treatment of Class II malocclusion. Am J Orthod Dentofacial Orthop. 1990;98(2):134-44.

Meach CL. A cephalometric comparison of bony profile changes in Class II, division 1 patients treated with extraoral force and functional jaw orthopedics. Am J Orthod. 1966;52(5):353-70.

Melo ACM. Avaliação cefalométrica do efeito do tratamento da má oclusão Classe II, divisão 1, com o bionator de Balters: estudo com implantes metálicos. Rev Dent Press Ortodon Ortoped Facial. 2006;11(3):18-31. 
Melrose C, Millett DT. Toward a perspective on orthodontic retention? Am J Orthod Dentofacial Orthop. 1998;115(5):507-14.

Miguel JAM. Rationale for referring Class II patients for early orthodontic treatment. J Appl Oral Sci. 2005;13(3):312-7.

Mills CM, McCulloch KJ. Posttreatment changes after successful correction of Class II malocclusions with the twin block appliance. Am J Orthod Dentofacial Orthop. 2000;118(1):24-33.

Mills JR. The effect of functional appliances on the skeletal pattern. Br J Orthod. $1991 ; 18(4): 267-75$.

Moyers RE, Riolo ML, Guire KE, Wainright RL, Bookstein FL. Differential diagnosis of class II malocclusions. Part 1. Facial types associated with class II malocclusions. Am J Orthod. 1980;78(5):477-94.

Nalbantgil D, Arun T, Sayinsu K, Fulya I. Skeletal, dental and soft-tissue changes induced by the Jasper Jumper appliance in late adolescence. Angle Orthod. $2005 ; 75(3): 426-36$.

Nanda RS, Nanda SK. Considerations of dentofacial growth in long-term retention na stability: is active retention need? Amer J Orthodont Dentofac Orthop. 1992;101(4):297-302.

Nascimento JE, Carvalho LS. Tratamento da má oclusão de Classe II divisão 1a através de recursos ortodônticos e ortopédicos faciais (funcionais e mecânicos): relato de caso. Rev Clin Ortodon Dent Press. 2003;2(4):81-91.

Nelson BG. Extraoral anchorage in the treatment of Class II, division 1 malocclusion its possibilities and limitations. Angle Orthod. 1953;23(2):121-33.

Nelson C, Harkness M, Herbison P. Mandibular changes during functional appliance treatment. Am J Orthod Dentofacial Orthop. 1993;104(2):153-61.

Nelson WE, Higley LB. The length of mandibular basal bone in normal occlusion and Class I malocclusion compared to Class II, division 1 malocclusion. Amer J Orthodont. 1948;34(7):610-7. 
Ngan PW, Byczec E, Scheik J. Longitudinal evaluation of growth changes in Class II division 1 subjects. Sem Orthod. 1997;3(4):222-31.

O'mullane DM. Some factors predisposing to injuries of permanent incisors in school children. Br Dent J. 1973;134(8):328-32.

Oliveira AJ. Avaliação cefalométrica comparativa das alterações esqueléticas, dentárias e faciais ocorridas em pacientes com má oclusão de classe II, divisão 1, tratados com tração extra bucal ortopédica e com Bionator de Balters. J Bras Ortodon Ortop Facial. 1997;2(10):51-63.

Oliveira Júnior JN. Avaliação comparativa das alterações dentoesqueléticas promovidas pelos aparelhos Jasper Jumper e extrabucal com ancoragem cervical, ambos associados à aparelhagem fixa no tratamento da Classe II, Divisão 1, de Angle. Dissertação (Mestrado) - Faculdade de Odontologia de Bauru: Universidade de São Paulo. 2002.

Oliveira Júnior JN AR. Avaliação cefalométrica comparativa das alterações dentoesqueléticas promovidas pelos aparelhos Jasper Jumper e extrabucal com ancoragem cervical, ambos associados à aparelhagem fixa no tratamento da Classe II, divisão 1, de Angle. Rev Dent Press Ortodon Ortoped Facial. 2004;9(2):50-68.

Op Heij DG, Callaert H, Opdebeeck HM. The effect of the amount of protrusion built into the bionator on condylar growth and displacement: a clinical study. Amer J Orthodont Dentofac Orthop. 1989;95(5):401-9.

Oppenheim A. Prognatism from the anthropolocial and orthodontics viewpoints. Dent Cosmos. 1928;70(12):1170-84.

Ormiston JP, Huang GJ, Little RM, Decker JD, Seuk GD. Retrospective analysis of long-term stable and unstable orthodontic treatment outcomes. Am J Orthod Dentofacial Orthop. 2005;128(5):568-74; quiz 669.

Pae EK, McKenna GA, Sheehan. TJ, Garcia R, Kuhlberg A, Nanda R. Role of lateral cephalograms in assessing severity and difficulty of orthodontic cases. Am J Orthod Dentofacial Orthop. 2001;120(3):254-62. 
Pancherz H. Relapse after activator treatment. A biometric, cephalometric, and electromyographic study of subjects with and without relapse of overjet. Am J Orthod. $1977 ; 72(5): 499-512$.

Pancherz $\mathrm{H}$. A cephalometric analysis of skeletal and dental changes contributing to Class II correction in activator treatment. Am J Orthod. 1984;85(2):125-34.

Pancherz H, Fackel U. The skeletofacial growth pattern pre- and post-dentofacial orthopaedics. A long-term study of Class II malocclusions treated with the Herbst appliance. Eur J Orthod. 1990;12(2):209-18.

Pancherz H, Fischer S. Amount and direction of temporomandibular joint growth changes in Herbst treatment: a cephalometric long-term investigation. Angle Orthod. 2003;73(5):493-501.

Paquette DE, Beattie JR, Johnston Jr. LE. A long-term comparison of nonextraction and premolar extraction edgewise therapy in "borderline" Class II patients. Am J Orthod Dentofacial Orthop. 1992;102(1):1-14.

Pavlow SS, McGorray SP, Taylor MG, Dolce C, King GJ, Wheeler TT. Effect of early treatment on stability of occlusion in patients with Class II malocclusion. Am J Orthod Dentofacial Orthop. 2008;133(2):235-44.

Pfeiffer JP, Grobety D. The class II malocclusion: differential diagnosis and clinical application of activators, extraoral traction, and fixed appliances. Am J Orthod. $1975 ; 68(5): 499-544$.

Piers EV, Harris DB. Piers-Harris children's self-concept scale. Rev manual / Los Angeles, Calif, Western Psychological Services. 1984.

Proffit WR. Contemporary orthodontics. Contemporary orthodontics 2 ed ed St Louis: Mosby. 1993.

Proffit WR. Forty-year review of extraction frequencies at a university orthodontic clinic. Angle Orthod. 1994;64(6):407-14.

Proffit WR, Tulloch JF. Preadolescent Class II problems: treat now or wait? Am J Orthod Dentofacial Orthop. 2002;121(6):560-2. 
Rabie AB, She TT, Hagg U. Functional appliance therapy accelerates and enhances condylar growth. Am J Orthod Dentofacial Orthop. 2003a;123(1):40-8.

Rabie AB, Wong L, Tsai M. Replicating mesenchymal cells in the condyle and the glenoid fossa during mandibular forward positioning. Am J Orthod Dentofacial Orthop. 2003b;123(1):49-57.

Remmer KR, Mamandras AH, Hunter WS, Way DC. Cephalometric changes associated with treatment using the activator, the Frankel appliance, and the fixed appliance. Am J Orthod. 1985;88(5):363-72.

Renfroe EW. A study of the facial patterns associated with Class I, Class II, division 1, and Class II, division 2 malocclusions. Angle Orthodont. 1948;18(1-2):12-5.

Richmond S, Shaw WC, O'Brien KD, Buchanan IB, Jones R, Stephens CD. Thedevelopment of the PAR Index (Peer Assessment Rating): reliability and validity. Eur J Orthod. 1992a;14(2):125-39.

Richmond S, Shaw WC, Roberts CT, Andrews M. The PAR Index (Peer Assessment Rating): methods to determine outcome of orthodontic treatment in terms of improvement and standards. Eur J Orthod. 1992b;14(3):180-7.

Ricketts RM. A four-step method to distinguish orthodontic changes from natural growth. J clin Orthodont. 1975;9(4):208-28.

Riedel RA. The relation of maxillary structures to cranium in malocclusion and in normal occlusion. Angle Orthodont. 1952;22(3):142-5.

Righellis EG. Treatment effects of Frankel, activator and extraoral traction appliances. Angle Orthod. 1983;53(2):107-21.

Riolo MLea. An atlas of craniofacial growth: cephalometric standards from the University School Growth Study, The University of Michigan. An atlas of craniofacial growth: cephalometric standards from the University School Growth Study, The University of Michigan Ann Arbor, Center for Human Growth and Development. 1974.

Rondeau $\mathrm{BH}$. Class II malocclusion in mixed dentition. J Clin Pediatr Dent. 1994;19(1):1-11. 
Rosenblum RE. Class II malocclusion: mandibular retrusion or maxillary protrusion? Angle Orthodont. 1995;65(1):49-62.

Rothstein T, Yoon-Tarlie C. Dental and facial skeletal characteristics and growth of males and females with class II, division 1 malocclusion between the ages of 10 and 14 (revisited)-part I: characteristics of size, form, and position. Am J Orthod Dentofacial Orthop. 2000;117(3):320-32.

Rothstein TL. Facial morphology and growth from 10 to 14 years of age in children presenting Class II, Division 1 Malocclusion: a comparative roentgenographic cephalometric study. Am J Orthod. 1971;60(6):619-20.

Ruf S, Pancherz H. Dentoskeletal effects and facial profile changes in young adults treated with the Herbst appliance. Angle Orthod. 1999;69(3):239-46.

Sadowsky C, Schneider BJ, BeGole EA, Tahir E. Long-term stability after orthodontic treatment: nonextraction with prolonged retention. Am J Orthod Dentofacial Orthop. $1994 ; 106(3): 243-9$.

Salzmann JA. Criteria for extraction in orthodontic therapy related to dentofacial development. Amer J Orthodont. 1949;35(8):584-610.

Santos MAC. Caracterização cefalométrica da Classe II, 1a divisão, esquelética Dissertação (Mestrado) - Faculdade de Odontologia de Bauru: Universidade de São Paulo. 2003.

Sarhan OA, Hashim HA. Dento-skeletal components of class II malocclusions for children with normal and retruded mandibles. J Clin Pediatr Dent. 1994;18(2):99-103.

Sassouni V. A classification of skeletal facial types. Am J Orthod. 1969;55(2):109-23.

Sassouni V. The Class II syndrome: differential diagnosis and treatment. Angle Orthod. 1970;40(4):334-41.

Scheideman GB, et al. Cephalometric analysis of dentofacial normals. Amer J Orthodont. 1980;78(4):404-20.

Schudy FF. The Rotation of the Mandible Resulting from Growth: Its Implications in Orthodontic Treatment. Angle Orthod. 1965;35:36-50. 
Schulhof RJ, Engel GA. Results of Class II functional appliance treatment. J Clin Orthod. 1982;16(9):587-99.

Servoss JM. Classification of occlusion. ASDC J Dent Child. 1975;42(1):28-30.

Sinclair PM, Little RM. Dentofacial maturation of untreated normals. Amer J Orthodont. 1985;88(2):146-56.

Southard TE, Behrents RG, Tolley EA. The anterior component of occlusal force. Part 1. Measurement and distribution. Am J Orthod Dentofacial Orthop. 1989;96(6):493-500 .

Starnes LO. Patient brochure for two-phase treatment. J Clin Orthod. $1991 ; 25(8): 503-4$.

Steiner CL. Cephalometrics as a clinical tool. In: KRAUS, B; RIEDEL, R Vistas in orthodontics Philadelphia, Lea \& Fabiger. 1962:131-61.

Stucki N, Ingervall B. The use of the Jasper Jumper for the correction of Class II malocclusion in the young permanent dentition. Eur J Orthod. 1998;20(3):271-81.

Thilander B. Orthodontic relapse versus natural development. Am J Orthod Dentofacial Orthop. 2000a;117(5):562-3.

Thilander B. Biological Basis for Orthodontic Relapse. Semin Orthod. 2000b;6(3):195-205.

Thuer U, Ingervall B, Burgin W. Does the mandible alter its functional position during activator treatment? Am J Orthod Dentofacial Orthop. 1989;96(6):477-84.

Toruño JLA. Efeitos do regulador de função Ic, de Fränkel, no tratamento da Classe II. [Tese (Doutorado)] Bauru: Universidade de São Paulo. 1999.

Tsamtsouris $A$, Vedrenne $D$. The use of the bionator appliance in the treatment of Class II, division 1 malocclusion in the late mixed dentition. J Pedod. 1983;8(1):78104. 
Tulloch JF. The effect of early intervention on skeletal pattern in Class II malocclusion: a randomized clinical trial. Am J Orthod Dentofacial Orthop. 1997;111(4):391-400.

Tulloch JF, Phillips C, Proffit WR. Benefit of early Class II treatment: progress report of a two-phase randomized clinical trial. Am J Orthod Dentofacial Orthop. 1998;113(1):62-72, quiz 3-4.

Tulloch JF, Proffit WR, Phillips C. Influences on the outcome of early treatment for Class II malocclusion. Am J Orthod Dentofacial Orthop. 1997;111(5):533-42.

Ursi W, McNamara JA, Jr. Crescimento craniofacial em pacientes apresentando maloclusões de Classe II e maloclusões normal, entre os e os 10 e os 12 anos de Idade. Rev Dental Press Ortodon Ortop Maxilar. 1997;2(5):49-59.

Ursi WJS. Alteração clínica da face em crescimento: uma comparação cefalométrica entre os aparelhos extrabucal cervical, Fränkel (FR-2) e Herbst, no tratamento das más-oclusões de classe II, primeira divisão de Angle. [Tese (Doutorado)] Bauru: Universidade de São Paulo. 1993.

Ursi WJS. Crescimento e alterações nas relações mandibulares dos 6 aos 18 anos de idade. Ortodontia. 1996;29(1):4-12.

Valladares-Neto J, Domingues MHMS, Capellozza-Filho L. Pesquisa em ortodontia: bases para a produção e a análise crítica. Rev Dent Press Ortod Ortop Facial. 2000;5(4):89-105.

Vargervik K, Harvold EP. Response to activator treatment in Class II malocclusions. Am J Orthod. 1985;88(3):242-51.

Voudouris JC, Kuftinec MM. Improved clinical use of Twin-block and Herbst as a result of radiating viscoelastic tissue forces on the condyle and fossa in treatment and long-term retention: growth relativity. Am J Orthod Dentofacial Orthop. $2000 ; 117(3): 247-66$.

Voudouris JC, Woodside DG, Altuna G, Angelopoulos G, Bourque PJ, Lacouture CY. Condyle-fossa modifications and muscle interactions during Herbst treatment, Part 2. Results and conclusions. Am J Orthod Dentofacial Orthop. 2003a;124(1):13-29. 
Voudouris JC, Woodside DG, Altuna G, Kuftinec MM, Angelopoulos G, Bourque PJ. Condyle-fossa modifications and muscle interactions during herbst treatment, part 1. New technological methods. Am J Orthod Dentofacial Orthop. 2003b;123(6):604-13.

Webster T, Harkness M, Herbison P. Associations between changes in selected facial dimensions and the outcome of orthodontic treatment. Am J Orthod Dentofacial Orthop. 1996;110(1):46-53.

Weiland FJ, Bantleon HP. Treatment of Class II malocclusions with the Jasper Jumper appliance-a preliminary report. Am J Orthod Dentofacial Orthop. 1995;108(4):341-50.

Wheeler TT, McGorray SP, Dolce C, King GJ. The timing of Class II treatment. Am J Orthod Dentofacial Orthop. 2006;129(4 Suppl):S66-70.

Wheeler TT, McGorray SP, Dolce C, Taylor MG, King GJ. Effectiveness of early treatment of Class II malocclusion. Am J Orthod Dentofacial Orthop. 2002;121(1):917.

Wieslander L. Long-term effect of treatment with the headgear-Herbst appliance in the early mixed dentition. Stability or relapse? Am J Orthod Dentofacial Orthop. 1993;104(4):319-29.

Wieslander L, Lagerstrom L. The effect of activator treatment on class II malocclusions. Am J Orthod. 1979;75(1):20-6.

Woodside DG. Do functional appliances have an orthopedic effect? Am J Orthod Dentofacial Orthop. 1998;113(1):11-4.

Yokota S, Murakami T, Shimizu K. A growth control approach to Class II, Division 1 cases during puberty involving the simultaneous application of maxillary growth restriction and mandibular forward induction. Am J Orthod Dentofacial Orthop. 1993;104(3):211-23. 
Apêndices 



\section{Apêndices}

A1 Severidade inicial da má oclusão de Classe II, $1^{\text {a }}$ divisão, dos pacientes que compuseram a amostra analisada.

\begin{tabular}{|c|c|c|}
\hline \multirow{2}{*}{ Paciente } & \multicolumn{2}{|c|}{ Severidade da Classe II } \\
\hline & Lado direito & Lado esquerdo \\
\hline A.A.A. & $3 / 4 \mathrm{Cl} \mathrm{II}$ & $3 / 4 \mathrm{Cl}$ II \\
\hline A.C.L.K. & $3 / 4 \mathrm{Cl} \mathrm{II}$ & Cl II completa \\
\hline A.L.O.G. & Cl II completa & Cl II completa \\
\hline B.L.T.G. & $3 / 4 \mathrm{Cl} \mathrm{II}$ & $\mathrm{Cl}$ II completa \\
\hline C.L.G. & $\mathrm{Cl}$ II completa & $\mathrm{Cl}$ II completa \\
\hline C.A.S.S. & Cl II completa & Cl II completa \\
\hline D.G.B.M. & Cl II completa & Cl II completa \\
\hline D.A.M. & $3 / 4 \mathrm{Cl}$ II & $3 / 4 \mathrm{Cl}$ II \\
\hline F.L.R. & $1 / 2 \mathrm{Cl} \mathrm{II}$ & Cl II completa \\
\hline G.C.H. & $\mathrm{Cl}$ II completa & Cl II completa \\
\hline G.M.S. & $3 / 4 \mathrm{Cl}$ II & $1 / 2 \mathrm{Cl}$ II \\
\hline G.O.C. & $3 / 4 \mathrm{Cl} \mathrm{II}$ & $1 / 2 \mathrm{Cl}$ II \\
\hline G.A.B. & $3 / 4 \mathrm{Cl}$ II & Cl II completa \\
\hline H.S.M. & $\mathrm{Cl}$ II completa & $\mathrm{Cl} \mathrm{I}$ \\
\hline J.G.B.Z. & $1 / 2 \mathrm{Cl}$ II & $1 / 2 \mathrm{Cl}$ II \\
\hline J.D.V. & Cl II completa & Cl II completa \\
\hline L.B.S. & $\mathrm{Cl}$ II completa & Cl II completa \\
\hline M.C.G. & $1 / 2 \mathrm{Cl}$ II & $3 / 4 \mathrm{Cl}$ II \\
\hline M.A.D. & Cl II completa & Cl II completa \\
\hline P.S.C.T. & Cl II completa & $3 / 4 \mathrm{Cl}$ II \\
\hline S.D.O. & $3 / 4 \mathrm{Cl}$ II & $3 / 4 \mathrm{Cl}$ II \\
\hline V.V. & Cl II completa & Cl II completa \\
\hline T.P. & Cl II completa & Cl II completa \\
\hline
\end{tabular}


A2 Idade nas fases inicial (T1), final (T2), longo tempo pós-tratamento (T3), bem como a diferença entre elas (T3 - T2), resultando, dessa maneira, no perído de longo tempo pós-tratamento (T2-T3), de cada paciente avaliado.

\begin{tabular}{|l|c|c|c|c|}
\hline \multirow{2}{*}{ Paciente } & \multicolumn{3}{|c|}{ Idades } & Período \\
\cline { 2 - 4 } & 11 & $\mathrm{~T} 2$ & $\mathrm{~T} 3$ & T2-T3 \\
\hline A.A.A. & 12,83 & 14,58 & 24,58 & 10 \\
\hline A.C.L.K. & 13,42 & 15,58 & 32,41 & 16,83 \\
\hline A.L.O.G. & 11,58 & 13,33 & 26,08 & 12,75 \\
\hline B.L.T.G. & 11,17 & 14,75 & 23,25 & 8,5 \\
\hline C.L.G. & 10,5 & 14 & 24,75 & 10,75 \\
\hline C.A.S.S. & 13,58 & 15,58 & 20,58 & 5 \\
\hline D.G.B.M. & 11,5 & 15,75 & 23,33 & 7,58 \\
\hline D.A.M. & 12,83 & 15,25 & 25,17 & 9,92 \\
\hline F.L.R. & 11,17 & 13,17 & 29,34 & 16,17 \\
\hline G.C.H. & 11,67 & 13 & 18,83 & 5,83 \\
\hline G.M.S. & 10 & 16,92 & 24,34 & 7,42 \\
\hline G.O.C. & 10 & 17,25 & 22,25 & 5 \\
\hline G.A.B. & 11,75 & 13,25 & 23,17 & 9,92 \\
\hline H.S.M. & 11,33 & 16,33 & 23,66 & 7,33 \\
\hline J.G.B.Z. & 12 & 18 & 26 & 9 \\
\hline J.D.V. & 14,42 & 15,5 & 32,92 & 17,42 \\
\hline L.B.S. & 12,17 & 19,5 & 26,5 & 7 \\
\hline M.C.G. & 10,42 & 14,58 & 24,83 & 10,25 \\
\hline M.A.D. & 11,58 & 14,17 & 23,25 & 9,08 \\
\hline P.S.C.T. & 9,92 & 14,75 & 23,75 & 9 \\
\hline S.D.O. & 9,92 & 17 & 23 & 6 \\
\hline V.V. & 12,92 & 14,25 & 23,25 & 15 \\
\hline T.P. & 13,5 & 17,33 & 29,58 & 12,25 \\
\hline
\end{tabular}


A3 Valores do índice PAR nas fases inicial (T1), final (T2), longo tempo póstratamento (T3), bem como a diferença entre esses valores no perído de tratamento (T1-T2), a \% de melhora e a de recidiva de cada paciente avaliado.

\begin{tabular}{|l|c|c|c|c|c|c|}
\hline \multirow{2}{*}{\multicolumn{1}{|c|}{ Paciente }} & \multicolumn{6}{|c|}{ PAR } \\
\cline { 2 - 7 } & PAR1 & PAR2 & PAR3 & PAR1-PAR2 & $\begin{array}{c}\text { \% de } \\
\text { melhora }\end{array}$ & $\begin{array}{c}\% \text { de } \\
\text { recidiva }\end{array}$ \\
\hline A.A.A. & 32 & 7 & 4 & 25 & 78,12 & 0,00 \\
\hline A.C.L.K. & 22 & 6 & 8 & 16 & 72,72 & 12,5 \\
\hline A.L.O.G. & 28 & 9 & 6 & 19 & 67,85 & 0,00 \\
\hline B.L.T.G. & 16 & 0 & 1 & 16 & 100,00 & 6,25 \\
\hline C.L.G. & 36 & 4 & 7 & 32 & 88,88 & 9,37 \\
\hline C.A.S.S. & 30 & 2 & 2 & 28 & 93,33 & 0,00 \\
\hline D.G.B.M. & 27 & 7 & 4 & 20 & 74,04 & 0,00 \\
\hline D.A.M. & 36 & 3 & 3 & 33 & 91,66 & 0,00 \\
\hline F.L.R. & 43 & 2 & 0 & 41 & 95,34 & 0,00 \\
\hline G.C.H. & 35 & 2 & 7 & 33 & 94,28 & 15,15 \\
\hline G.M.S. & 24 & 10 & 18 & 14 & 58,33 & 57,14 \\
\hline G.O.C. & 34 & 0 & 0 & 34 & 100,00 & 0,00 \\
\hline G.A.B. & 28 & 2 & 1 & 26 & 92,85 & 0,00 \\
\hline H.S.M. & 23 & 3 & 0 & 20 & 86,95 & 0,00 \\
\hline J.G.B.Z. & 29 & 6 & 6 & 23 & 79,31 & 0,00 \\
\hline J.D.V. & 30 & 6 & 7 & 24 & 80 & 4,16 \\
\hline L.B.S. & 36 & 7 & 7 & 29 & 80,55 & 0,00 \\
\hline M.C.G. & 25 & 4 & 2 & 21 & 84,00 & 0,00 \\
\hline M.A.D. & 36 & 12 & 14 & 24 & 66,66 & 8,33 \\
\hline P.S.C.T. & 34 & 11 & 11 & 23 & 67,64 & 0,00 \\
\hline S.D.O. & 31 & 7 & 7 & 24 & 77,41 & 0,00 \\
\hline V.V. & 28 & 9 & 9 & 19 & 67,85 & 0,00 \\
\hline T.P. & 30 & 5 & 5 & 25 & 83,33 & 0,00 \\
\hline
\end{tabular}

